\title{
SOLAR-ASSISTED LOW ENERGY DWELLINGS
}

FINAL REPORT OF THE:

MASTER

ZERO ENERGY HOUSE GROUP

OF THE:

NATO COMMITTEE ON THE CHALLENGES TO MODERN SOCIETY (CCMS) SOLAR ENERGY PILOT STUDY

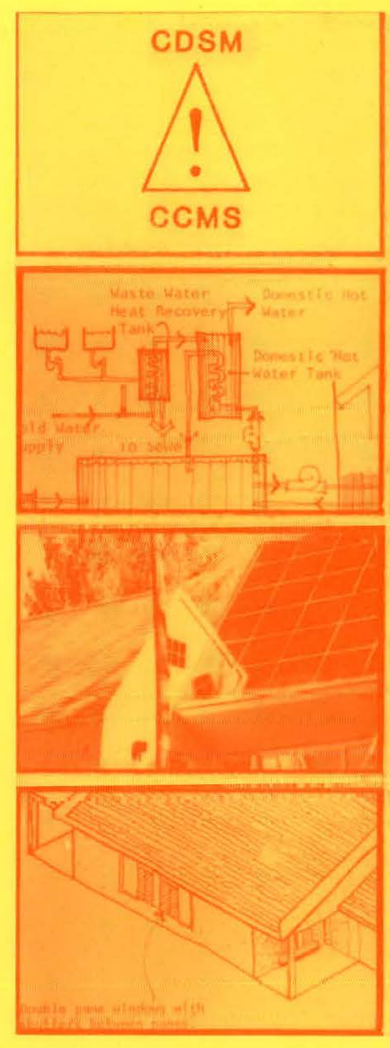

FEBRUARY 1980

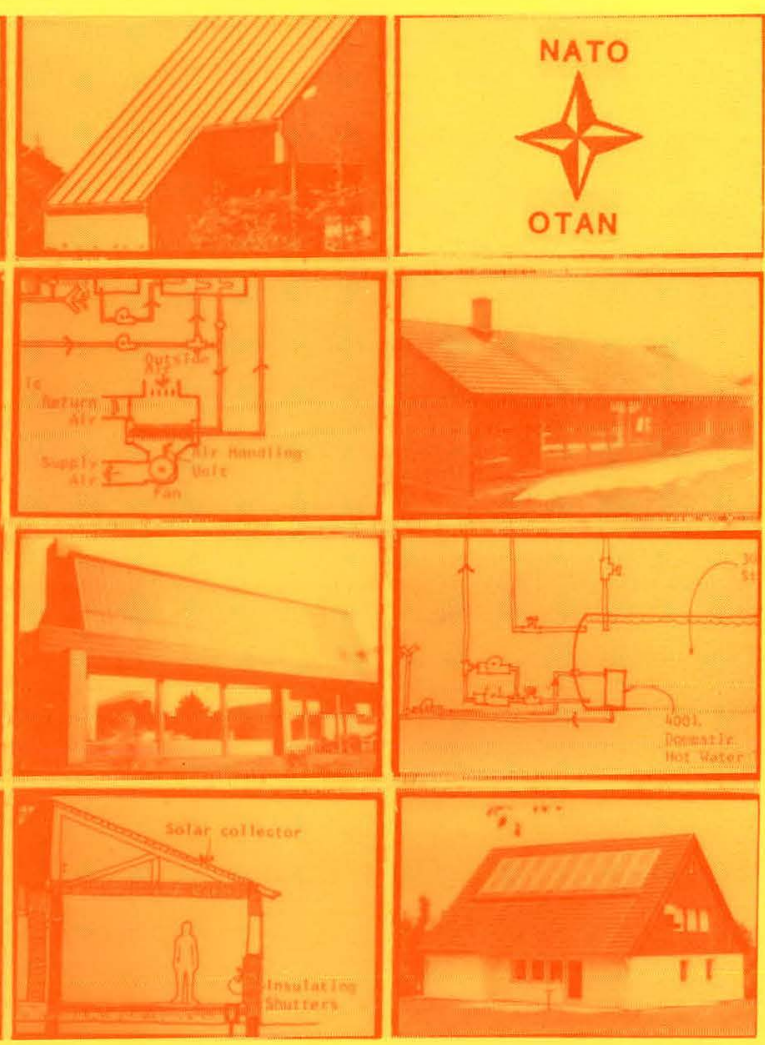

CCMS REPORT NO. 93 


\section{DISCLAIMER}

This report was prepared as an account of work sponsored by an agency of the United States Government. Neither the United States Government nor any agency Thereof, nor any of their employees, makes any warranty, express or implied, or assumes any legal liability or responsibility for the accuracy, completeness, or usefulness of any information, apparatus, product, or process disclosed, or represents that its use would not infringe privately owned rights. Reference herein to any specific commercial product, process, or service by trade name, trademark, manufacturer, or otherwise does not necessarily constitute or imply its endorsement, recommendation, or favoring by the United States Government or any agency thereof. The views and opinions of authors expressed herein do not necessarily state or reflect those of the United States Government or any agency thereof. 


\section{DISCLAIMER}

Portions of this document may be illegible in electronic image products. Images are produced from the best available original document. 


\section{DISCLAIMER}

"This book was prepared as an account of work sponsored by an agency of the United States Government. Neither the United States Government nor any agency thereof, nor any of their employees, makes any warranty, express or implied, or assumes any legal liability or responsibility for the accuracy, completeness, or usefulness of any information, apparatus, product, or process disclosed, or represents that its use would not intringe privately owned rights. Reference herein to any specific commercial product, process, or service by trade name, trademark, manufacturer, or otherwise, does not necessarily constitute or imply its endorsement, recommendation, or favoring by the United States fonvernment nr any agency thereof. The views and opinions of authors expressed herein do not necessarily state or reflect those of the United States Government or any agency thereof."

This report has been reproduced directly from the best available copy.

Available from the National Technical Information Service, U. S. Department of Commerce, Springfield, Virginia 22161.

Price: Paper Cupy $\$ 9.00$

Microfiche \$3.50 
SOLAR-ASSISTED LOW ENERGY DWFI.LINGS

NATO COMMITTEE ON THE CHALLENGE TO MODERN SOCIETY (CCMS)

SOLAR ENERGY PILOT STUDY

ZERO ENERGY HOUSE GROUP

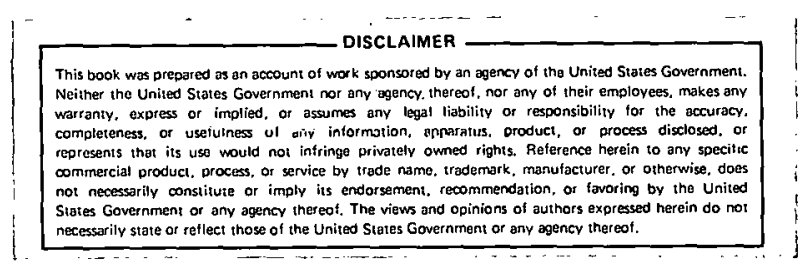

Prepared for the:

U. S. Department of Energy

Assistant Secretary for Conservation and Solar Energy

Office of Solar Applications

Prepared by:

Torben V. Esbensen M.Sc.

$\checkmark$ Mortensen \& Esbensen, Consulting Engineerings ApS Mollegade 54-56, 6400 Sonderborg, Denmark

Trorodvej 73, 2950 Vedbak, Denmark

Under Contract No. EY 76-S-05-4.908

and

Burt Hill Kosar Rittelmann Associates 400 Morgan Center

Butler, Pennsylvania 


\section{THIS PAGE \\ WAS INTENTIONALLY LEFT BLANK}




\section{CONTENTS}

Zero Energy House Group.................. 1

State-of-the-Art in Low-Energy Dwellings......... 5

13 Solar Assisted Low-Energy Dwellings 15

1. Zero Energy House at Lyngby, Denmark........16

2. Team Kudu Low Energy House at Skive, Denmark...26

3. LN Low-Energy House at Skive, Denmark........34

4. Low-Energy Houses at Hjortekaer, Denmark......40

5. Termoroc Low-Energy House at Limhamn, Sweden...46

6. Mikkonen Low-Energy House at Bollebygd, Sweden. 54

7. Passive Solar House at Vetlanda, Sweden.......60

8. Philips Experimental House at Aachen, FRG....66

9. Eindhoven Solar House, Netherlands..........74

10. Goosebrook Solar Home at Harrisville, New Hampshire, Us.................... 80

11. Minimum Energy Dwelling in Mission Viejo,

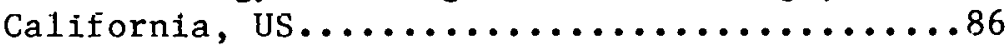

12. Mississauga Solar House, Ontario, Canada......994

13. Saskatchewan Conservation House,

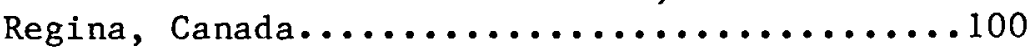




\section{ILLUSTRATIONS}

\begin{tabular}{|c|c|c|}
\hline Figure: & . & Page \\
\hline 1 & Low Energy Technology Development & 6 \\
\hline 2 & Planting Concepts & 8 \\
\hline 3 & Surface to Volume Ratio & 8 \\
\hline 4 & U.S. Indoor Design Temperature Historic & 11 \\
\hline 5 & Comfort Zone and Energy Use & 11 \\
\hline 6 & Metering Affects of Energy Use & 12 \\
\hline 7 & Zero Energy House in Denmark & 16 \\
\hline 8 & Heating and Ventilation System & 18 \\
\hline 9 & Solar Energy System & 20 \\
\hline 10 & Srorage Tank ( $30 \mathrm{~m}^{3}$ ) Buried in the Ground & 20 \\
\hline 11 & Calculated and Measured Energy Balance & 23 \\
\hline 12 & Team Kudu Low-Energy House & 26 \\
\hline 13 & Plan Arrangement & 26 \\
\hline 14 & Cross Section In Team Kudu House & 29 \\
\hline 15 & Solar and Wind Energy System & 30 \\
\hline 16 & Water Brake in the Storage Tank & 31 \\
\hline 17 & Calibration Curve for the Water Brake & 31 \\
\hline 18 & ra1sulated Energy Balance & 32 \\
\hline $1 y$ & LN Low-Energy House & 34 \\
\hline 20 & Snlar Energy System & 37 \\
\hline 21 & $\mathrm{H}+\mathrm{H}$ Low-Energy House & 40 \\
\hline 22 & Solar Energy System & 43 \\
\hline 23 & Six Low-Energy Houses (Mode1-Photo) & 44 \\
\hline 24 & Calculated Energy Balance & 44 \\
\hline 25 & Termoroc Low-Energy House & 46 \\
\hline 26 & Insulated Windows Screen & 49 \\
\hline 27 & Crosa Section in Teiluvioc Huuse & 50 \\
\hline 28 & Mikkonen Low-Energy House & 54 \\
\hline
\end{tabular}


30 Vetlanda Passive Solar Home 60

Southfacing Windows 


\section{ABSTRACT}

The Zero Energy House Group was formed as a subproject of the CCMS Solar Energy Pilot Study in 1974 by seven participating countries experimenting with snlar-assisted low-energy dwellings for temperate and northern European, climatic conditions. A "Zero Energy House" is one in which solar energy is used to meet the reduced energy needs of huildings incorporating various thermal energy conservation features. This report is intended as the final report of the Zero Energy House Group. It includes brief descriptions of 13 major low-energy dwellngs in the participating CCMS countries. The report also contains an overa11 dssessuent of the state-of-the-art in colar=aesisted low-energy dwellings. 
A

ZERO ENERGY

HOUSE GROUP 
The NATO Committee on the Challenges of Modern Society (CCMS) was established in 1969 in response to the complex technological and environmental problems facing industrialized nations. CCMS has become an effective mechanism for identifying these challenges and establishing cooperative programs which respond to these issues by the sharing of efforts and resources. CCMS maintains a policy of open-publication and open membership, as the problems with which it deals are of global concern.

Recognizing that sufficient supplies of energy are essential to the maintenance of the quality of life in industrialized societies and for continued world-wide progress and growth, CCMS turned its attention, at an early date, to the imperatives of alternative energy development and energy conservation. In 1973, collaborative pilot studies were established in geothermal energy, advanced automative propulsion systems, solar energy, and energy conservation.

\section{SOLAR ENERGY PILOT STUDY}

The CCMS Solar Energy Pilot Study was initiated at the end of 1973, with the United States serving as pilot country and Denmark and France as co-pilot countries. Over 20 countries (both NATO and non-NATO nations plus the Éuropean Commission) have participated in this program. The objective of the pilot study was to encourage the cost-effective and practical application of solar energy to heating and cooling of buildings. The scope of the program was defined as exchange of information on solar heating, cooling and domestic hot water systems, with special emphasis on the reporting of national programs and system performance.

Specific activities undertaken by the participants included:

Annual review of national solar heating and cooling program at pilot study meetings 
- Development of a standardized system performance reporting format

- Exchange of reports on the performance of operational solar heating and cooling systems in the participating countries, utilizing the aforementioned format

- Establishment of specialized working groups in solar-assisted low-energy dwellings (Zero Energy House Group) and passive technology (Passive Solar Applications Group).

The Solar Energy Pilot Study was completed in. October 1978 and a two-year follow-up phase inillulcul al ihat rime.

\section{ZERO ENERGY HOUSE GROUP}

From the reports presented on national solar heating and cooling programs at the first pilot study meeting, it became apparent that certain groups of countries, having similar climates and building needs, were stressing similar applications. As a result, the Zero Energy House Group was formed in 1974, by those participating countries experimenting with solar-assisted low-energy dwellings for tomperate and northern European-type climatic conditions, in order to share experiences and promote close working ties between researchers. In the context of this project, a "Lero Energy House" is one in which solar energy is used to meet the reduced energy needs of buildings incorporating various thermal energy conservation features.

The group las been chatred by protessor Vagn Korsgaard of Denmark. The seven countries which participated in this working group are Canada, Denmark, Federal Republic of Germany, The Netherlands, Sweden, United Kingdom, and the United

States. Three meetings of the Zero Energy House Group were held In Denmark, Germany and Sweden. These meetings enabled technical experts from those seven countries to meet in a small group for informal and detailed exchange of information on the design aspects and performance measuresments of lowenergy house projects, and had an impact as well on the specific design characteristics of those projects. In addition to the technical exchange, 
experts have appreciated the opportunity to establish close ties with their colleagues working on similar projects in other countries.

At the conclusion of the pilot study, the participants were requested to assess the effectiveness of the program. Based on the responses, the Zero Energy House Group appears to have been a successful collaboration. Enthusiasm for this subproject was high, as evidenced by the expressed desire to continue this specialized cooperation. Examples of Respondents' comments were:

"The Zero Energy House Group was highly efficient."

"...very effective. Results of prime importance for understanding the thermodynamic behavior of modern housing technologies."

"Found group to be most helpful and influential. Exchange of views with other designers significantly influenced design of our own low-energy experiments."

"Interchange on innovative design and engineering concepts was of significant value."

When a CCMS pilot study is completed, the members often recommend that all or part of the activities be transferred to another international organization. The Zero Energy House participants requested that the International Energy Agency (IEA) Solar Heating and Cooling Program initiate a low-energy dwelling project to permit continuation of the cooperation which was judged to have been valuable. This is presently beling implemented by the IEA.

Remaining technical problems and those areas in which further investigation is needed were 1dentified. The following topics are recommended possible subjects for future cooperative efforts:

(1) Economic evaluation of low-energy dwellings
(a) Approaches to the definition of incremental costs
(b) Cost studies 
(2) Cooperative performance measurements in low-energy dwellings

(a) Study of approaches

(b) Performance prediction

(c) Measurement of performance

(3) Cooperative research in seasonal storage, for countries with high heating loads and low insolation.

This document is intended as the final report of the Zero Energy House Group. It includes brief descriptions of 13 major low-energy dwellings in the participating CCMS countries. The report also contains an overall assessment of the state-of-theart in solar-assisted low-energy dwellings. 
B

STATE OF THE ART 
This state-of-the-art report is compiled from a review of the 13 projects described and analyzed in the second section of this book. In a cursory overview, all aspects of each project cannot be given an in-depth review. There are, however, some main areas that can be commented upon. Among these are house siting, building envelope, internal loads and user habits, each of which is oriented to the technologies that conserve energy. Another set of topics that deals with energy use and generation is mechanical equipment: heating systems, cooling systems, domestic hot water vent1lation systems and on-site renewable energy generating technology.

Before reporting on the development of the technology it may be usetul to show in some schematic way that the development of the solar assisted low energy dwelling is not a static process, but that it is an inter-related series of developments.

If the development of low energy dwelling technologies could be graphed, it might look like F1gure 1. Along the time-line new concepte develop that are part of the genre of housing technology. As the concepts develop some physical form, Llie culture as a whole selects those that are most applicable until the most operational forms are fixed by use. There is then a later stage that reassesses the final operational forms as new information and pressures demand. Within this abstract time line, energy rechnologies can be placed corresponding to what stage one sees their development.

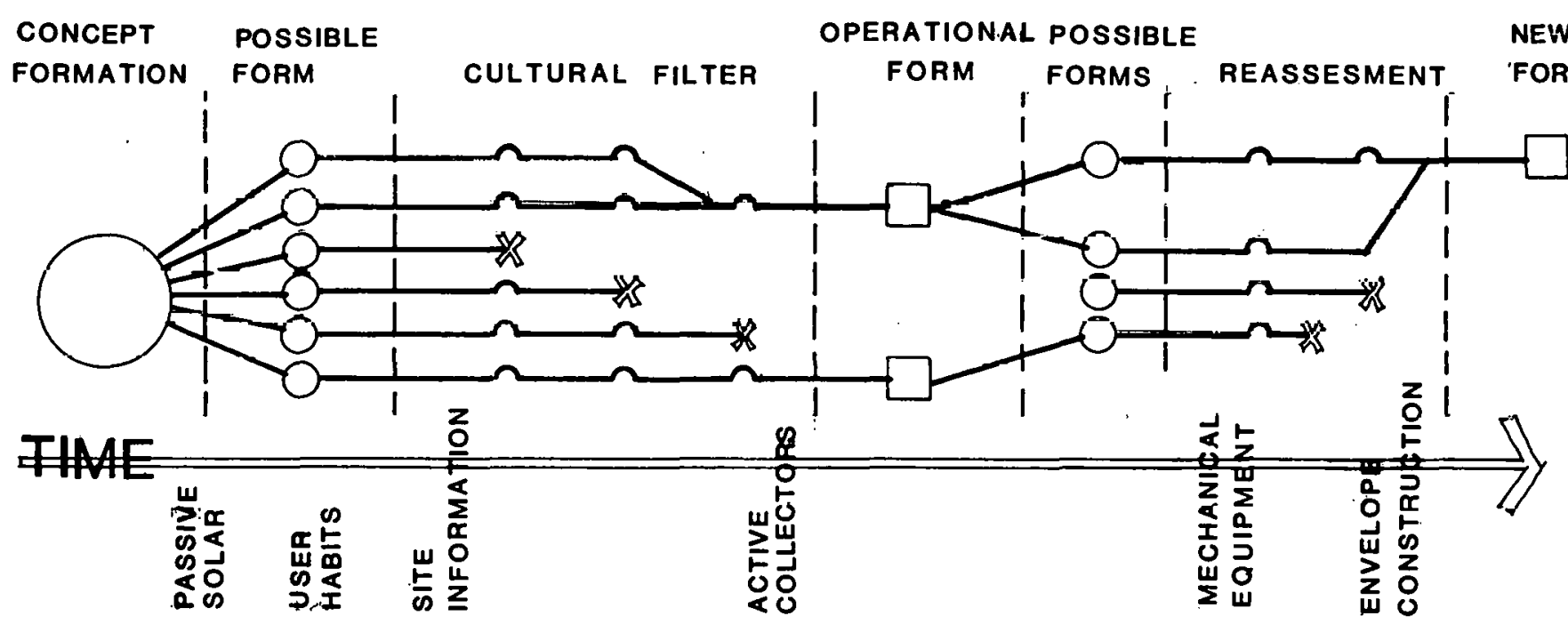


Though this graph is only one possibility, it may illustrate more clearly the various technologies now developing due to new energy-related pressures.

\section{SITE DEVELOPMENT}

The physical placement of the building, siting, has several impacts on the energy use of the building. Siting can refer to the location of a building on its particular lot or to its location within a larger environment and each of these affects energy use. For example, the effect of siting on energy use is seen in the sub-urban setting where transportation costs become an important factor. Transporting building materials to the site, plus the energy needed for residents to commute from the house to work both can make a substantial difference in energy consumption depending on the house's location. Though this energy use is not part of the building's energy it is directly related to the construction of the house. At a small scale, that of the immediate plot plan, there are energy influences that have their impact. Orientation to take advantage of solar energy is the prime concern that has been studied thoroughly to date. Other areas of concern which need more research and quantification are energy conservation, landscaping and use of natural topography. In general, knowledge of site design remains at the conceptual level and needs to be applied, studied and reported. The gap that exists between what is known conceptually about site energy influences and that which has been studied and quantified needs to be closed.

Examples that could serve as guides for further research and documentation on both the large and small scale are found in The Cost of Sprawl. 1 This research drew some conclustons about different housing configurations that were segregated according to their density characteristics.

As mentioned, conceptual design information at the level of the immediate site is well understood, but the quantitative information available is not complete. At this time, the best that can be shown are concept diagrams that illustrate known phenomena.

1. Real Estate Reseach Corporation, The Cost of Spraw1, U.S. Government Printing Office, Washington, D.C. April, 1974 


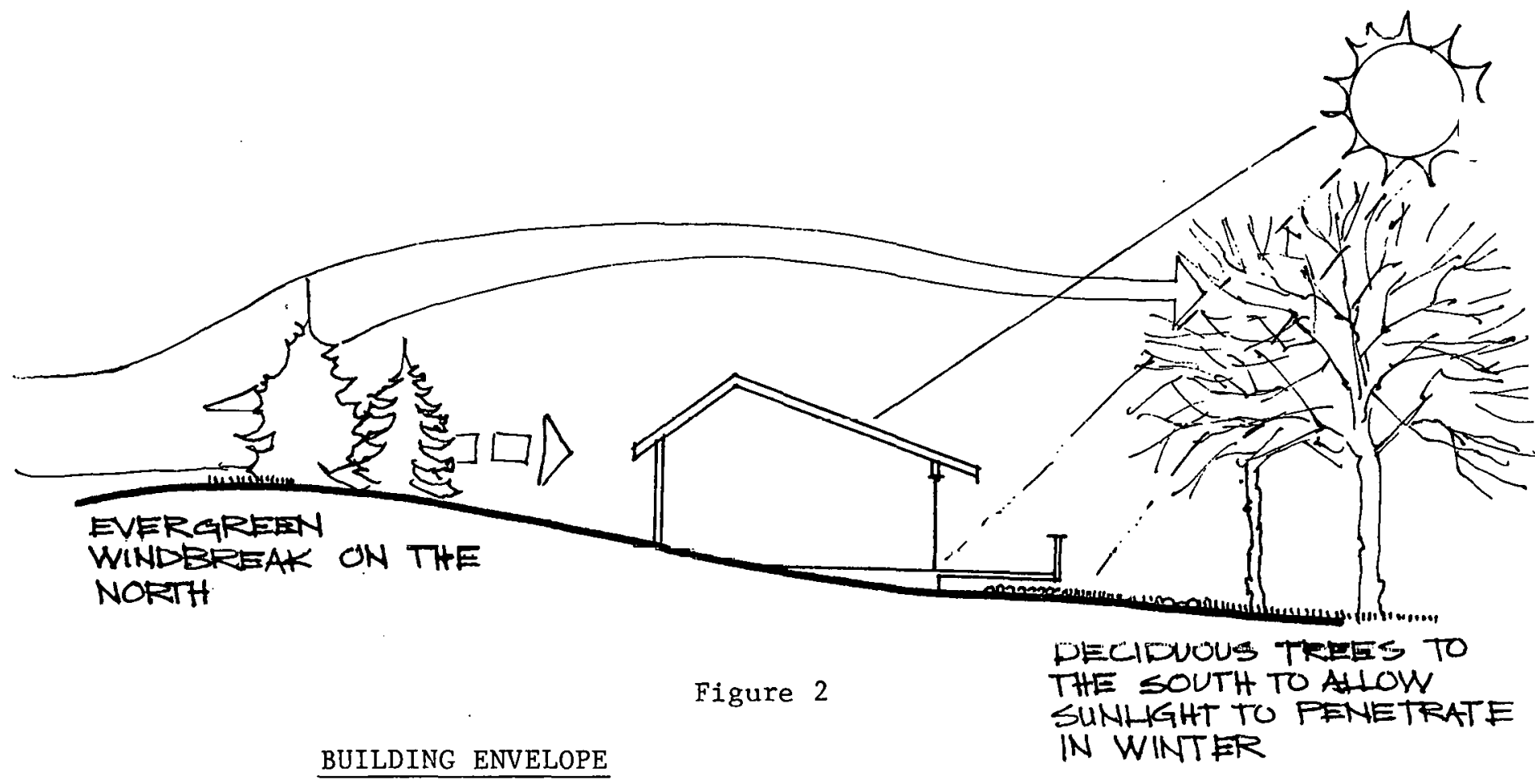

The building envelope, the skin that protects the building from environmental forces, has been shown to be very important in the conservation of energy in the low energy house. The dominant energy loads in a house are environmentally induced and thus the exterior skin is a prime energy conservation tool. The envelope is the filter to the environment allowing positive ellviroimental traits through and blocking unwanted natural phenoment. The energy conservation components of the envelope are insulation, infiltration control, openings, and structural mass. At the outset, before analyzing the construction detajis, it is important to mention that the skin surface to floor area ratio of the building will be a determinant in the amount of energy used in the structure. The following can serve to illustrate this point very well.

HEAT

LOAD

$5000 \mathrm{~kW}$

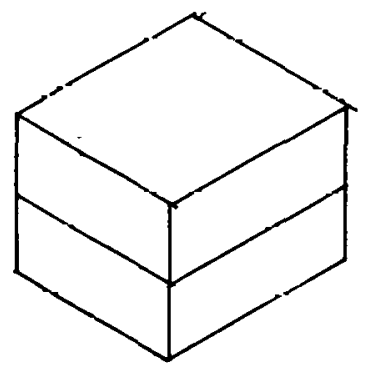

FLOOR AREA SURFACE AREA $\frac{120 M^{2}}{270 M} 2=.44$

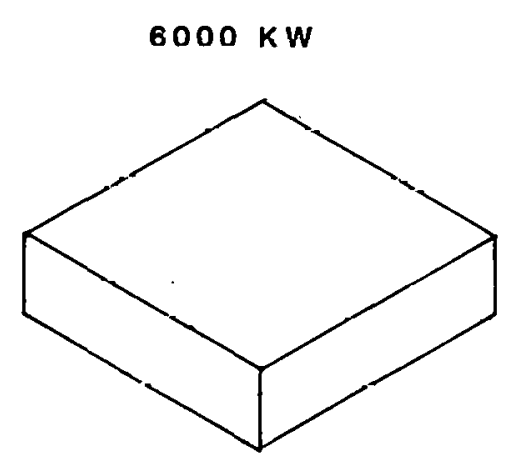

$\frac{120 M^{2}}{345 M^{2}}=.35$
$6300 \mathrm{KWW}$

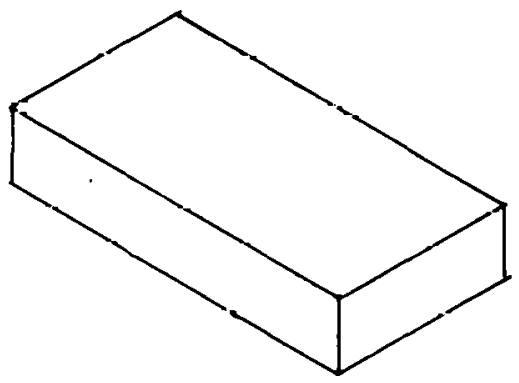

$\frac{120 M^{2}}{355 M^{2}}=.34$ 
This concept can be used effectively to reduce energy consumption at early stages of design. As the surface area is first adjusted to the minimum surface to floor area ratio consistant with the micro climate and the building program requirements, the construction can then be details for energy conservation.

A review of the houses built in recent years shows that the exterior wall envelope insulation that can be constructed has a k-value of.15-.20 W/m $\mathrm{m}^{2} \mathrm{x}^{\circ} \mathrm{C}$ $(R-30)$. This value is an average of wall, roof, and floor insulation values. Along with insulation, construction that prevents thermal short circuiting along structural members is being designed by providing thermal breaks. Methods used to provide thermal breaks are; building separate inner and outer walls and the use of sandwich construction panels that use insulation as structure.

To provide an even better insulated shell, the window openings can have moveable insulation installed over them. These openings can then have the $k$-value reduced from $2 \mathrm{~W} / \mathrm{m}^{2} \mathrm{x}^{\circ} \mathrm{C}$ for triple glazed window to $.5 \mathrm{~W} / \mathrm{m}^{2} \mathrm{x}^{\circ} \mathrm{C}$ when the insulation is drawn over the openings such as during the night.

Houses that are well insulated have a proportiona11y larger amount of their heat loss attributable to outside air infiltration. From $1 / 3$ to $1 / 2$ of the heat loss can come from leaks in the building envelope. Tight building construction is the answer to many leak problems. Panelized wall construction to eliminate field joints is one of the construction techniques being used here. A vapor barrier that has integrity, with joints well lapped and sealed, and with electrical outlets and other necessary openings sealed, is also necessary for good air infiltration control. Openings should have good weatherstripping and operation hardware to stop alr flow. The construction of a tight house reduces infiltration to .2 air changes per hour at air speeds of $4-5 \mathrm{~m} / \mathrm{s}(9-11 \mathrm{mph})$. These air change rates fluctuate depending on envelope construction. If construction is not controlled and air infiltration increases to .4 air changes per hour the energy use of a solar assisted low energy dwelling would increase approximately $50 \%$.

To provide for good air quality with this low rate of natural infiltration, a mechanical ventilation system is installed. This will be covered under mechanical equipment. 
There is some development with parts of the building envelope which function in two ways. An example of this is the hollow cinderblock cellar wall that is used as fresh air tempering device in the Philips experimental house at Aachen, FRG. The use of a vapor barrier that doubles as air infiltration barrier is also a common example. The use of windows as a solar heating aperture as well as the other functions that a window performs is probably the most common example of providing double duty with a single envelope component.

INTERNAL LOADS

Internal loads are now studied more thoroughly for their effect on energy usage. These loads are no longer discounted when energy balance is calculated as they are significant energy inputs. Internal loads can be a positive or negative load depending on whether the heating or cooling system is in use. Therefore care must be taken to account for the reversable nature of these loads. During the heating season, the loads from appliances can offset 46 percent of the heating load of a low energy house. The energy use of these appliances should be studied not only for the efficiency with which they use energy but also for the secondary effects that their waste heat has on loads of the building. Energy that is saved in the use of the appliances does not affect the other energy requirements of the house so as appliances conserve more energy, the internal loads will go down, influencing the size of heat storage tanks and other mechanical equipment.

\section{USER HABITS}

People and their habits are also important for the actual attainment of low energy use. Although this aspect of energy use is not usually considered the province of the researcher, knowledge of user habits necd to be understood and applied to rechnology for thorough energy conservation. A good graphic example of uger habits as they relate to cncrgy uoc is the figure on the following page that shows the gradual Increase of thermostat set point in the U.S. 


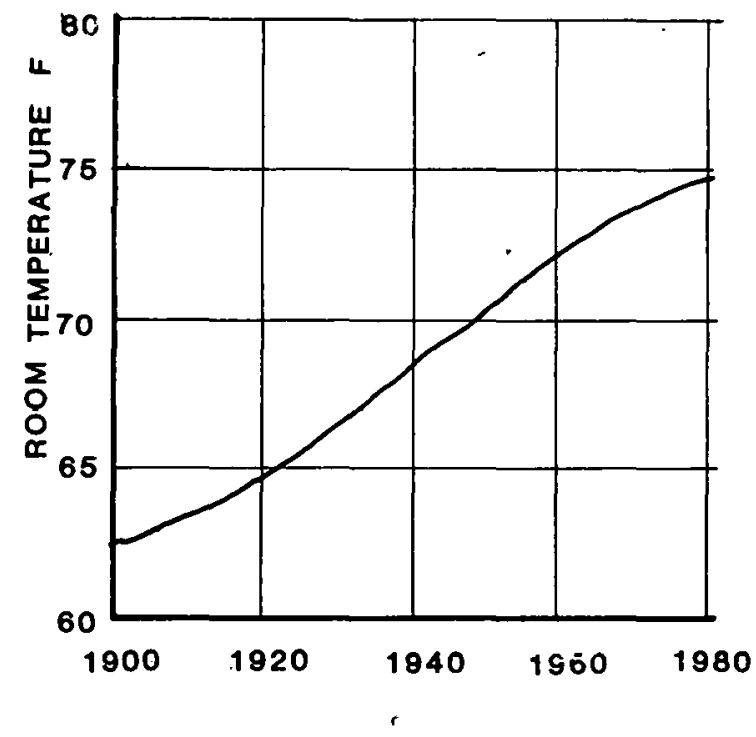

Figure 4

Another useful concept for the occupant to understand is the "comfort zone" and the relationship that this has on energy use. (The graph shown gives a conceptual feel for the energy use for different limit set points of the comfort zone. As clearly shown, the more tolerant the set points, the less energy is used.

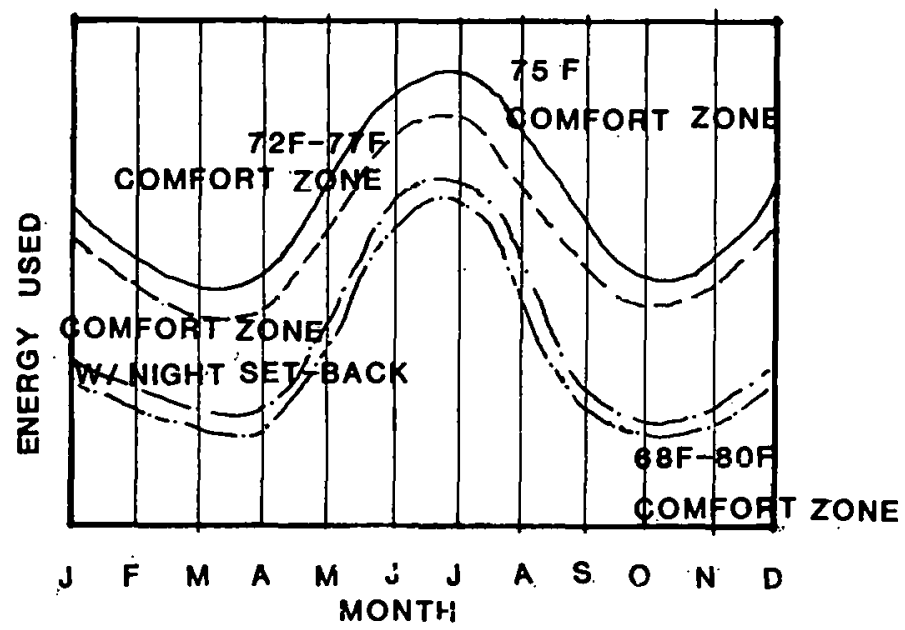

Figure 5

In the Minimum Energy Dwelling, Mission Viejo, California, there was a $46 \%$ energy savings by setting comfort zone limits at $20^{\circ}$ to $26.6^{\circ} \mathrm{C}\left(.68^{\circ}\right.$ to $80^{\circ} \mathrm{F}$ ) instead of keeping the temperature exactly on $28.8^{\circ} \mathrm{C}\left(75^{\circ} \mathrm{F}\right)$.

1. Nevins, R.G., Psychometrics and Modern Comfort (Presented at the Jüinl A3HRAE-A3MC Meeling, November 28-29, 1961). 
As these examples show, the house occupant has a great influence over energy usage of the building. It then follows that there should be ways of providing energy usage feedback to the occupant. It has been shown that information feedback to occupants has had dramatic effect on energy usage.

An example of energy conservation studied by Reiner and Adamson ${ }^{2}$ showed the decrease of hot water consumption between buildings that had individual hot water meters and those buildings which did not. This study showed 40-50\% less hot water usage in buildings with individual meters as compared with those flats that did not have separate meters.

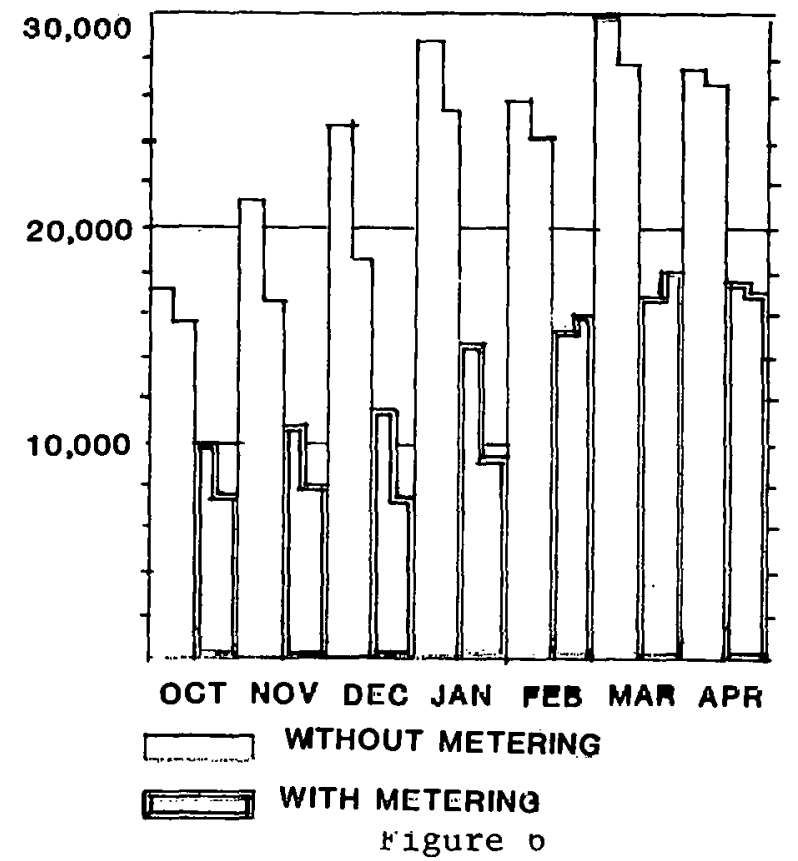

This type of study and others need to be integrated to the low energy house technology studies to more completely understand the inter-relationship of user and technology on energy consumption.

MECHANICAL EQUTPMENT

We finally come to the set of topics that deal with energy use and energy generacion. This is properly the province of the mechanical systems that provide the necessary space conditioning that conservation measures alone cannot handle because of extremes of the climate or economic constraints that limit the type of construction in the building envelope.

\section{Reiner, E. and Adamson, B. 1957 Prov.med fordelningsmatare for vmarme och varmvatten (Statens namned for byggnadsforskiing) Rapport nr 36.}


With energy costs increasing, the types and sizes of mechanical systems selected for houses are being chosen more carefully. These systems are being analyzed after the building is first designed to accept the energy available from the climate.

\section{HEAT RECLAIM}

As mentioned earlier, the tightly constructed house is the rule with the low energy house. A mechanical ventilation system is then needed to provide proper comfort levels for the occupants. These systems are equipped with heat exchangers so that the incoming cold air is heated by exhaust air stream. These heat exchangers are typically $60-70 \%$ efficient.

Another heat reclaiming system prevalent in the low energy house is a waste water heat reclamation system. This system takes advantage of cascading use of energy to improve efficiency in burning of source fuels. The system's efficiencies reported at $20-40 \%$. The effects of water conserving fixtures has a direct impact on the energy recovered from this type of system, therefore, careful analysis of changing water use patterns must be looked at in designing a waste water energy recovery system.

\section{AUXILIARY HEAT}

In the heating system, the heat pump is the preferred auxiliary source of energy. This system has the advantage of increasing the BTU output of auxiliary electrical energy through the refrigeration cycle. There is also some use of radiant panel heating. Radiant heating systems have an advantage of allowing the air temperature to cool to a lower set point but the room conditions still remain within the comfort zone. The majority of space heat delivery sỹstems are forced a1r. A cooling backup system is not used in the

European low energy house examples. In the U.S. where cooling is used, an economizer. cycle is part of the cooling system. This system uses large quantities of outside air, when temperature and humidity conditions are favorable, to supply cooling air to the house. This system works favorably when mass has been added to the building. When the mass has been cooled, for example, at night, th1s room will stay cool through the hottest time of the day reducing the peak cooling loads on refrigeration equipment. 
Alternative on-site renewable energy such as solar is used as an energy source for all of the homes to reduce the need for expensive fossil fuels. The typical active solar heating system consists of 20-30 $\mathrm{m}^{2}$ of flat plate collector aperture. The systems are generally hydronic with a 2-3 $\mathrm{m}^{3}$ short term heat storage tank. Each system is a custom design, which points to the fact that total solar system packages are not yet available to the building market and the architect/engineer must be involved with the design at this time.

rassive solar systems have been used in a few of the buildings. Here again more is known about the concepte of paosive oyotems than is currently under analysis. The studies at this point describe the energy available from the south facing windows. Further study and monitoring of structures is needed for passive solar technology.

\section{OVERVIEW}

An overall view of the solar assisted low energy house shows an auxiliary energy use of between .14 and $.17 \mathrm{~W} / \mathrm{m}^{2}{ }^{\circ} \mathrm{C} \quad\left(2-3 \mathrm{BTU} / \mathrm{SF}^{\circ} \mathrm{F}\right)$ The rest of the energy load is provided primarily by internal loads and solar energy system. Other energy sources are heat recovery of air and water systems and earth contact pipes or ducts. The mechanical systems are designed carcfully after the energy integrity of the building cnvelope has been assured by proper construction. 
C

13

SOLAR-ASSISTED

LOW ENERGY

DWELLINGS 


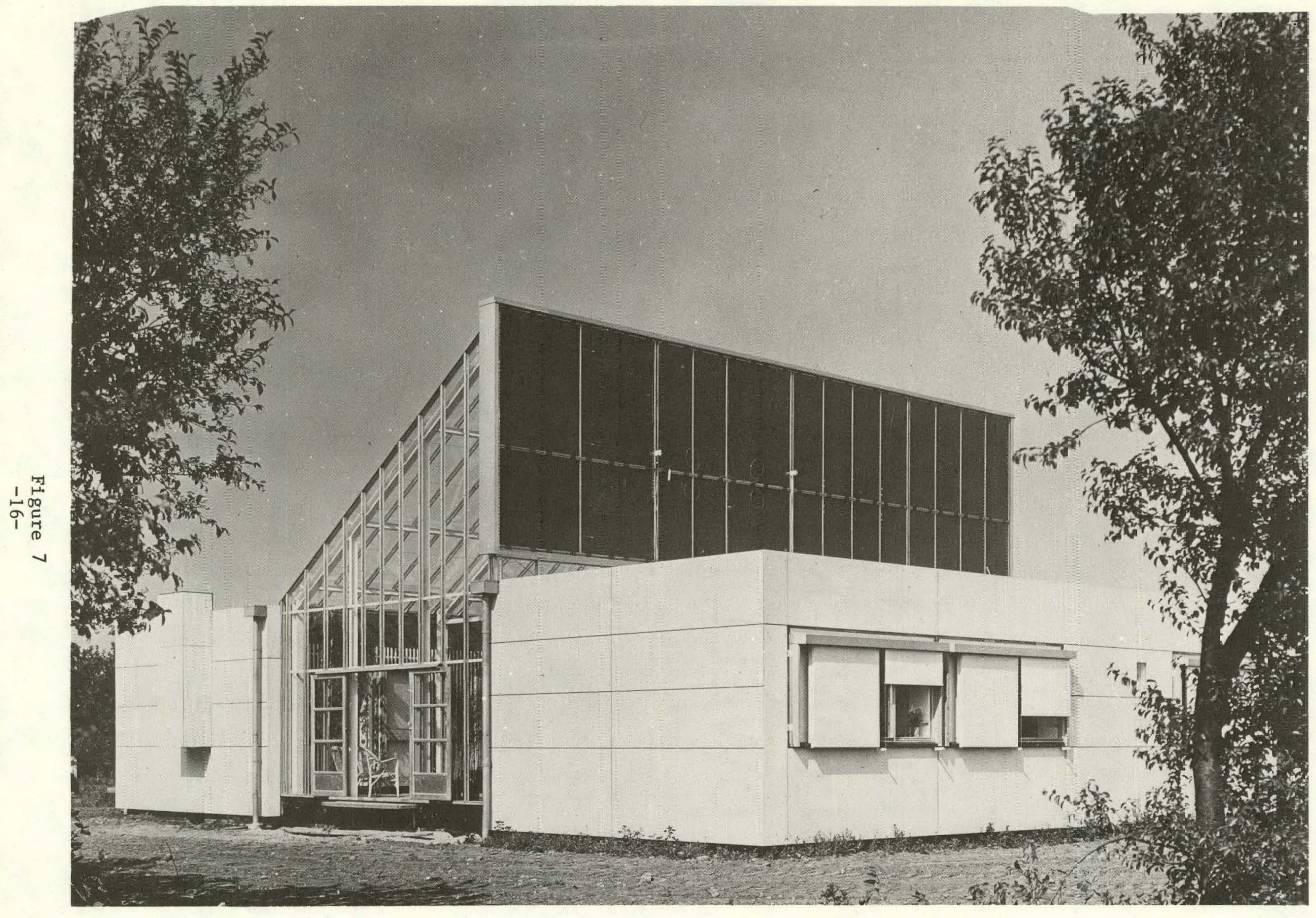




\section{THE ZERO ENERGY HOUSE at LYNGBY, DENMARK}

\section{A. DESCRIPTION}

The zero-energy house was built at The Technical University of Denmark in the spring of 1975 as an experimental house. The project was executed in collaboration by three institutes at the Technical University: The Thermal Insulation Laboratory, The Institute of Building Design and The Laboratory of Heating and Air Conditioning.

The objectives of the project were to construct a single-family house, which can, for the most part, be heated by the free heat from the residents, electric utensils, etc., and to demonstrate the technical feasibility of utilizing a solar heating system with seasonal heat storage, to supply the necessary additional heat, including heat for domestic hot water, under Danish climatic conditions.

From October 1976, to October 1977, the house was inhabited by a "standard family" consisting of two adults and two school-age children.

Monitoring data was taken in the period 1976-78, after which the house was used as a guest residence for the Technical University.

CLIMATIC CONDITIONS

The house is located at Lyngby at a latitude of $55^{\circ}$.

The mean annual number of sunshine hours is 1580 .

The mean value of the average ambient temperature is $8.0^{\circ} \mathrm{C}$, and the annual number of degree days is 2900 , calculated with $17^{\circ} \mathrm{C}$ as the design indoor temperature.

DESIGN OF THE BUILDING

The house is designed as two dwelling units $60 \mathrm{~m}^{2}$. each, separated by a glass-roofed atrium $70 \mathrm{~m}^{2}$. The atrium is not heated, but it is protected against wind and rain, and therefore it may be used as a part of the living area in the daytime hours during the main part of the year. 


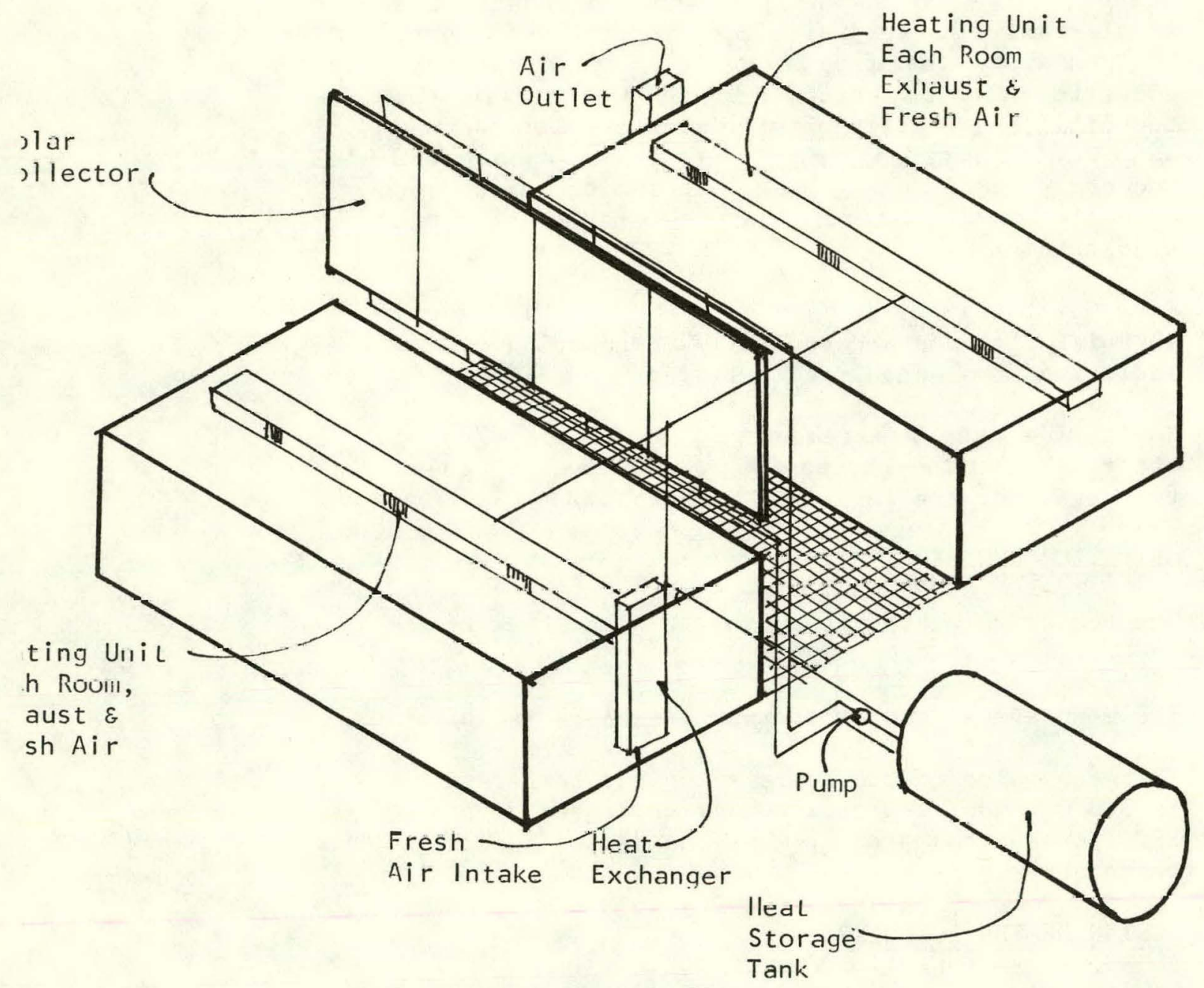

Figure 8 
The south facing upper vertical part of the atrium contains a flat-plate solar collector $42 \mathrm{~m}^{2}$.

\section{ENERGY CONSERVATION MEASURES}

The two prefabricated dwelling units in the Zero

Energy House are insulated to the following kvalues:

$$
\begin{array}{lll}
\text { Walls }(300 \mathrm{~mm} & & \\
\text { mineral wool): } & \mathrm{k}=0.14 \mathrm{~W} / \mathrm{m}^{2} \times{ }^{0} \mathrm{C} \\
\begin{array}{ll}
\text { Ceiling }(400 \mathrm{~mm} \\
\text { minera1 wool): }
\end{array} & \mathrm{k}=0.10 \mathrm{~W} / \mathrm{m}^{2} \times{ }^{0} \mathrm{C} \\
\begin{array}{ll}
\text { F1oor }(400 \mathrm{~mm} \\
\text { mineral wool): }
\end{array} & \mathrm{k}=0.10 \mathrm{~W} / \mathrm{m}^{2} \times{ }^{0} \mathrm{C}
\end{array}
$$

The windows are provided with two layers of glass and with insulated shutters to increase the insulation value during the night. The windows facing south are furthermore provided with a sun shading device. The windows have the following $\mathrm{k}$-values :

\section{Windows in daylight hours}

(2 layers of glass): $\mathrm{k}=3.0 \mathrm{~W} / \mathrm{m}^{2} \times{ }^{0} \mathrm{C}$

Windows at night

(Insulated shutters): $\mathrm{k}=0.5 \mathrm{~W} / \mathrm{m}^{2} \times{ }^{0} \mathrm{C}$

The house is very air-tight. Infiltration due to leaks around doors and windows and in the joints between elements is measured to 0.15 air changes per hour.

In order to obtain satisfactory air quality the house is equipped with a ventilation system which supplies $200 \mathrm{~m}^{3}$ of fresh air per hour, corresponding to an air change of 0.7 per hour.

The ventilation system is equipped with a heat recovery device working on the opposing current principle. The heat recovery device has a yearly efficiency measured to $70 \%$.

Warm air is used for space heating. A thermostatically controlled fan-coil unit is installed in the air duct in each room. In periods where none of the units call for heat the pump which circulates the water between the storage tank and the heating coils is stopped to minimize heat loss. 


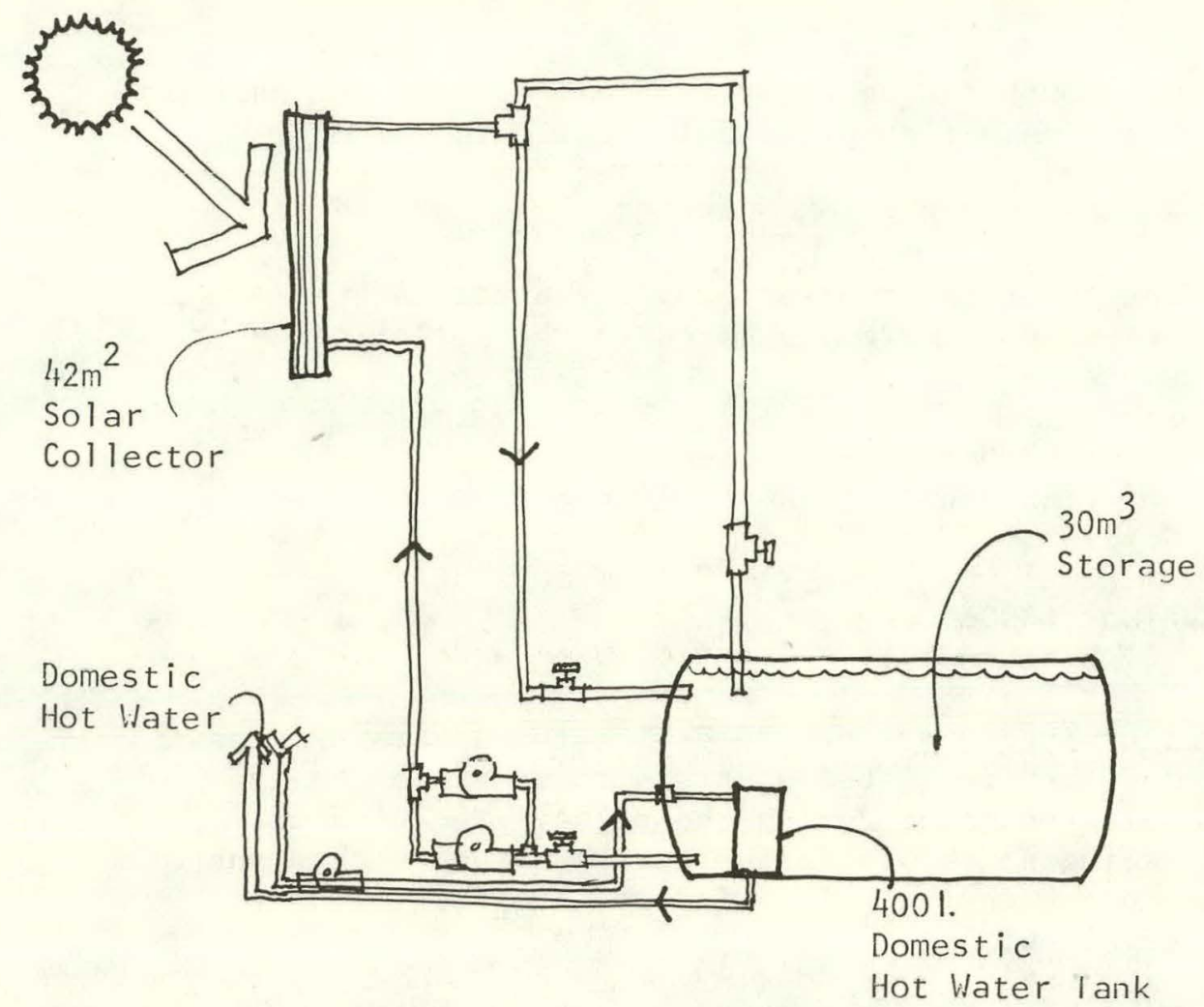

Figure 9

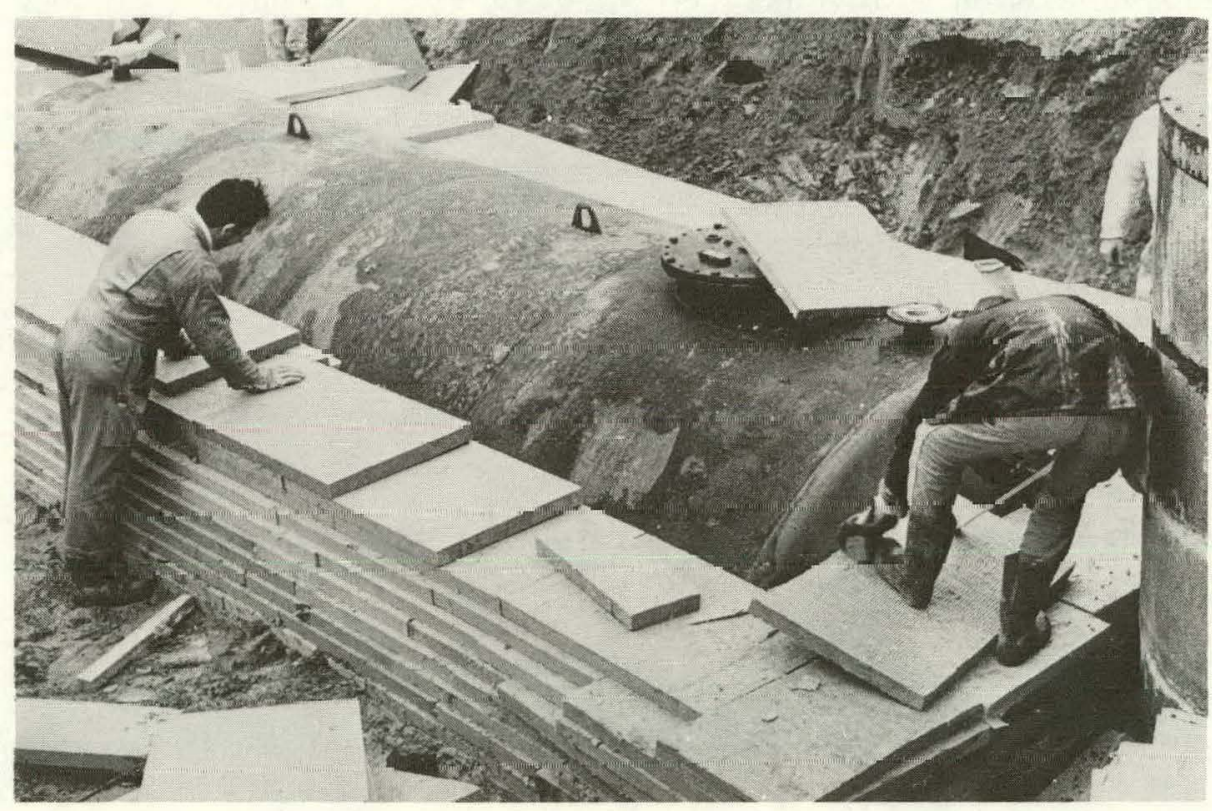

Figure 10 
The domestic hot water supply is based on a 400 liter hot water tank placed in the storage tank.

A heat recovery system is also part of the domestic hot water system, transferring heat from the warm waste water of showers and washing machine to cold inlet water for the water tank.

SOLAR HEATING SYSTEM

The solar heating system consists of a vertical, south-facing solar collector $\left(42 \mathrm{~m}^{2}\right)$, a heat storage tank $\left(30 \mathrm{~m}^{3}\right)$ and a control system.

The absorber is a flat-plate, roll-bond steel radiator painted with ordinary carbon black paint.

The front of the collector is standard, hermetically sealed, two-layer glass framed in steel bars and sealed with a mastic. It is insulated at the back with $250 \mathrm{~mm}$ of mineral wool.

The fluid is water, and the collector is protected against frost by draining the water during nonworking periods.

The storage medium is water, contained in a cylindrical steel tank, $2.5 \mathrm{~m}$ in diameter and $6.5 \mathrm{~m}$ long:

There is direct circulation between the storage tank and the solar collector, and the normal maximum temperature has been meaasured to $85^{\circ} \mathrm{C}$.

The storage tank is buried in the ground just outside the house, and it is insulated with $600 \mathrm{~mm}$ of mineral woul.

As auxiliary heat, an electric hot water system with a capacity of $4 \mathrm{~kW}$, is installed.

The efficiency of the solar energy system as measured is about $3 \%$ higher than calculated in the Reference Year. It corresponds with the fact that the temperature in the storage tank was lower in the measuring period than in the Reference Year. 
B. OPERATIONAL PERFORMANCE RESULTS

THE ENERGY BALANCE OF THE SOLAR HEATING SYSTEM

The original energy balance calculated for the period August 1 to July 31 during the Reference Year:

\begin{tabular}{|l|l|}
\hline $\begin{array}{l}\text { The amount of energy in the } \\
\text { storage tank (calculated } \\
\text { from } 0^{\circ} \mathrm{C} \text { ) per August } \quad 2600 \mathrm{kWh}\left(74^{\circ} \mathrm{C}\right)\end{array}$ \\
$\begin{array}{l}\text { Collected solar energy } \\
\text { August-July }\end{array}$ & \\
\hline & $7300 \mathrm{kWh}$ \\
\hline $\begin{array}{l}\text { SOLAR ENERGY UTILIZED AUGUST-JULY } \\
\text { For space heating }\end{array}$ & \\
$\begin{array}{l}\text { For domestic hot water } \quad 2300 \mathrm{kWh} \\
\text { Heat loss from the storage } 2700 \mathrm{kWh}\end{array}$ & \\
tank & $7300 \mathrm{kWh}$ \\
\hline
\end{tabular}

The amount of energy in

the storage tank per

July 31 at the end of the

Reference Year

$2600 \mathrm{kWh}$

$\left(74^{\circ} \mathrm{C}\right)$

The measured energy balance for the period Augus 1

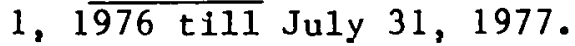

\begin{tabular}{l} 
The amount of energy in \\
the storage tank (calcu- \\
laled (rum $0^{\circ} \mathrm{C}$ ) per \\
August 1,1976 \\
Collected solar energy \\
in this period \\
SOLAR ENERGY UTILIZED AUG \\
For space heating \\
For domestic hot water \\
Heat loss from the \\
storage tank \\
\hline \\
The amount of energy in \\
the storage tank per \\
July 31 , 1977 at the end \\
of the test year
\end{tabular}

$2140 \mathrm{kWh}$ $\left(61^{\circ} \mathrm{C}\right)$ 


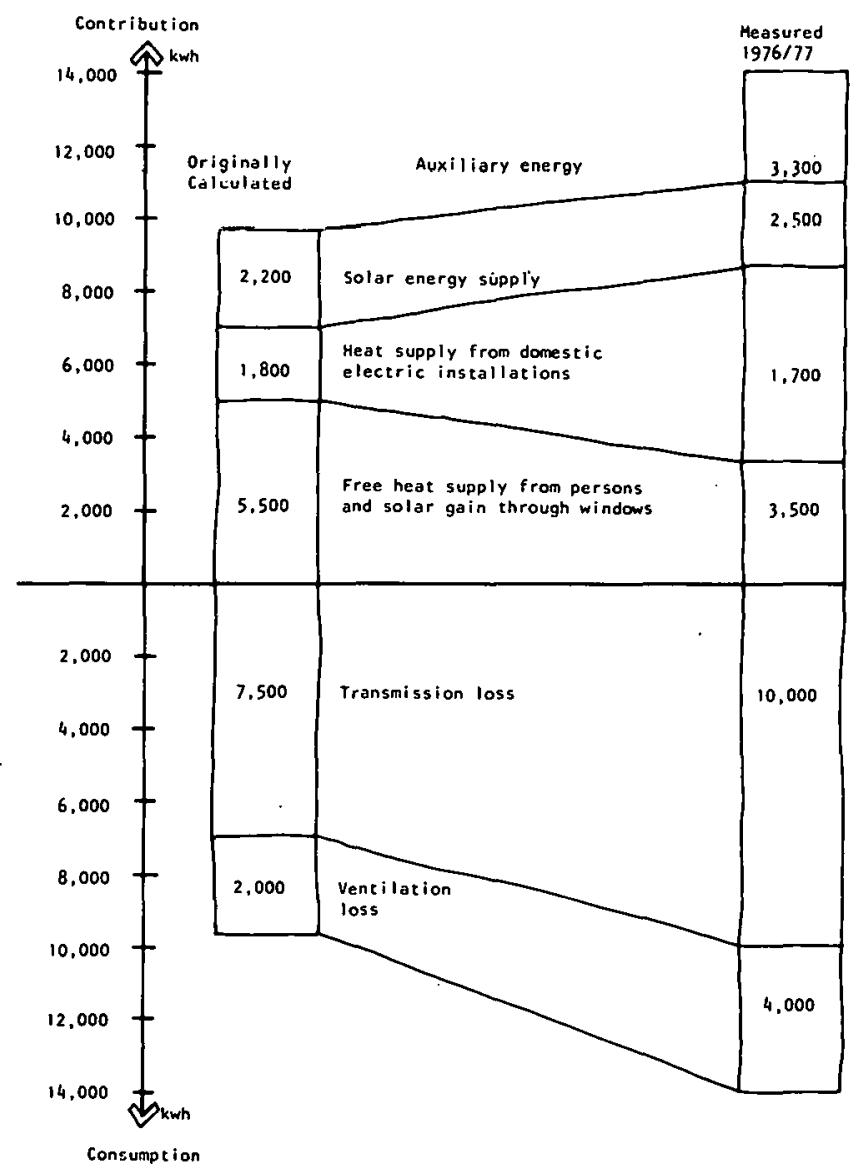

Figure 11

\section{PERFORMANCE RESULTS}

EFFICIENCY OF MOVABLE INSULATION

The k-value for windows with shutters was originally calculated to $0.4 \mathrm{~W} / \mathrm{m}^{2} \mathrm{x}{ }^{\circ} \mathrm{C}$. The $k$-value for the outside windows with shutters has been measured to $0.9 \mathrm{~W} / \mathrm{m}^{2} \mathrm{x}{ }^{\circ} \mathrm{C}$. This difference is due to thermal bridges in the construction and to ventilation in the space between windows and shutters due to the seal between window and shutter not being as tight as designed.

The k-value for the windows and shutters facing the atrium has been measured to $0.5 \mathrm{~W} / \mathrm{m}^{2} \mathrm{x}{ }^{\circ} \mathrm{C}$.

In this case the shutters are closed with magnetic locks, and therefore there is a high level of air tightness, and the thermal bridges have been reduced considerably. 


\section{SOLAR COLLECTOR}

The front of the collector is standard hermetically sealed, two-layer glass framed in steel bars and sealed with a mastic.

Under the worst conditions, which means no water circulating through the absorber plates and clear sunshine almost perpendicular to the collector, the temperatures in the collector are very high.

On a sunny day in February 1975, these conditions occurred. The temperature was measured at $140^{\circ} \mathrm{C}$ on the absorber, $120^{\circ} \mathrm{C}$ on the inner glass and $60^{\circ} \mathrm{C}$ on the outer glass. Due to this temperature difference of $60^{\circ} \mathrm{C}$ between the inner and outer glass, almnst $25 \%$ of the inner glass in the collector array broke.

Therefore it is very important that the cover glass is mounted in such a way that it is possible for the glass to move under the varying temperatures. Maybe it would be a better solution to use 2 single layers of glass instead of a hermetically sealed double glass.

\section{ECONOMICS}

The total cost of the entire solar system (collectors, storage tank, insulation, installation) was 180,000 Danish Crowns $(\$ 30,000$ US) in 1975.

The total conctruction cost of the Zero Energy House Project was 770,000 Danish Crowns $(\$ 130,000$ US) in 1975.

\section{USER REACTIONS}

The fam1ly who lived in the house in the period of Ocicober 1976 - Uccober 1977, had no comments on the solar installation.

During the oummer pcrind, the family used the atrium as a living room which means that the usable living space is increased with $50 \%$.

The windows facing south are relatively small, and they are provided with a sun shading device which means that there were no problems with high indoor temperatures on sunny days. 
It was very interesting to see if the family would feel comfortable in this highly insulated, very tight house during the winter period.

The family was very satisfied with the indoor climate. The ventilation system supplied the house with a sufficient amount of fresh air and it was not at any time necessary to open the windows to ventilate the room.

The only thing which is different in living in the Zero Energy House is to remember to close and open the insulating shutters.

\section{CONCLUSIONS}

With the energy conservation measures in the house, the heat requirement for space heating was calculated to $2300 \mathrm{kWh}$ per year. During the period October 1976 - October 1977, when the house was occupied by a typical family, the heat requirement, however, was measured to $5800 \mathrm{kWh}$. The main reasons for this difference are unintentional infiltration, a high rate of mechanical ventilation and a greater heat transmission loss than originally calculated.

The solar heating system was designed to cover the heat requirement for space heating and hot water supply during the entire year. During the 12month occupied period the solar radiation was only about $70 \%$ of the solar heat gain during the corresponding period in the Reference Year. Due to this reduction in solar radiation and due to the greater heat requirement, the solar heating system covered on 1 y $43 \%(2500 \mathrm{kWh})$ of the heat requirement for space heating ( $5800 \mathrm{kWh})$ and $27 \%$ $(1000 \mathrm{kWh})$ of the hot water load $(2700 \mathrm{kWh})$.

\section{REFERENCES}

(1) Esbensen, Torben V. and Vagn Korsgaard Dimensioning of the Solar Heating System in the Zero Energy House in Denmark. Solar Energy Vo1. 19, pp. 195-199, 1977.

(2) Esbensen, Torben V. and Vagn Korsgaard Performance of the Zero Energy House in Denmark 1. German Solar Energy Forum Vo1. 1 pp 11-24, 1977

(3) DTH-NUL-ENERGIHUS/ZERO-ENERGY-HOUSE Arkitektens Forlag, Copenhagen, 1977. 


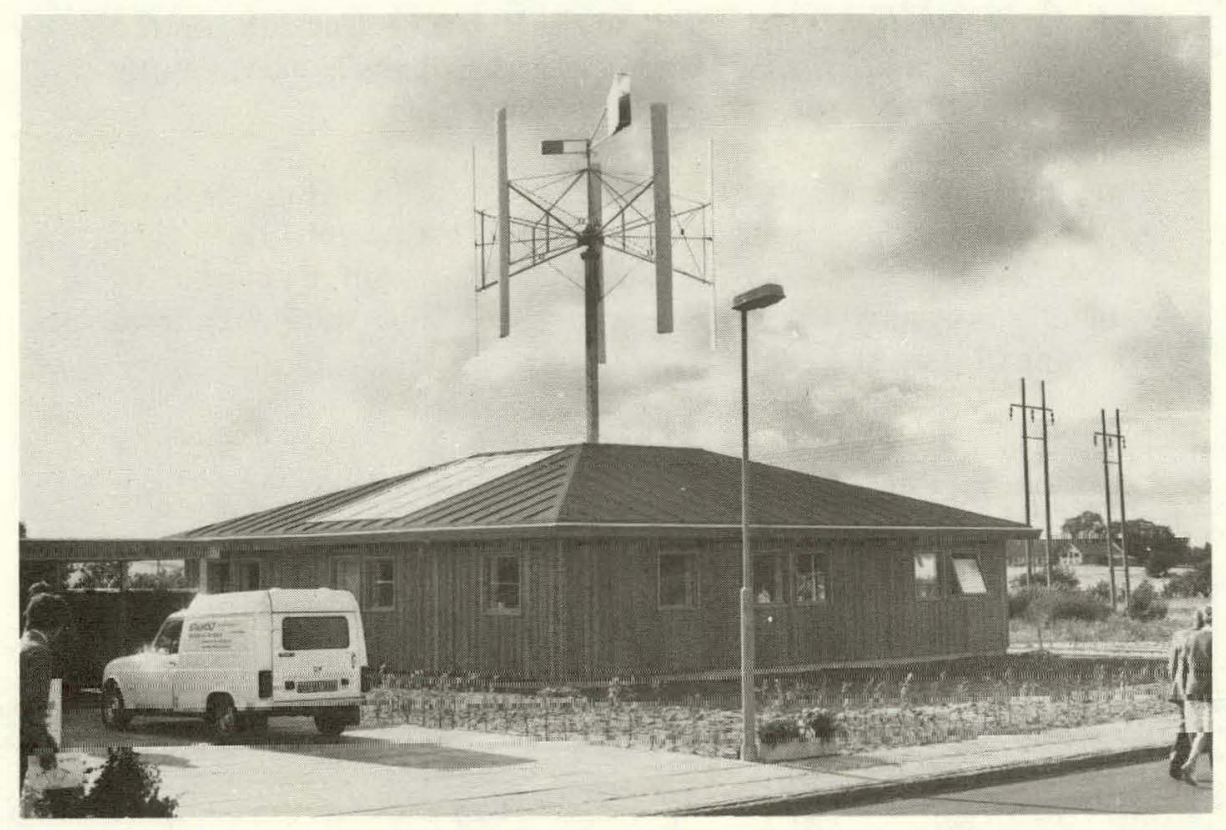

Figure 12

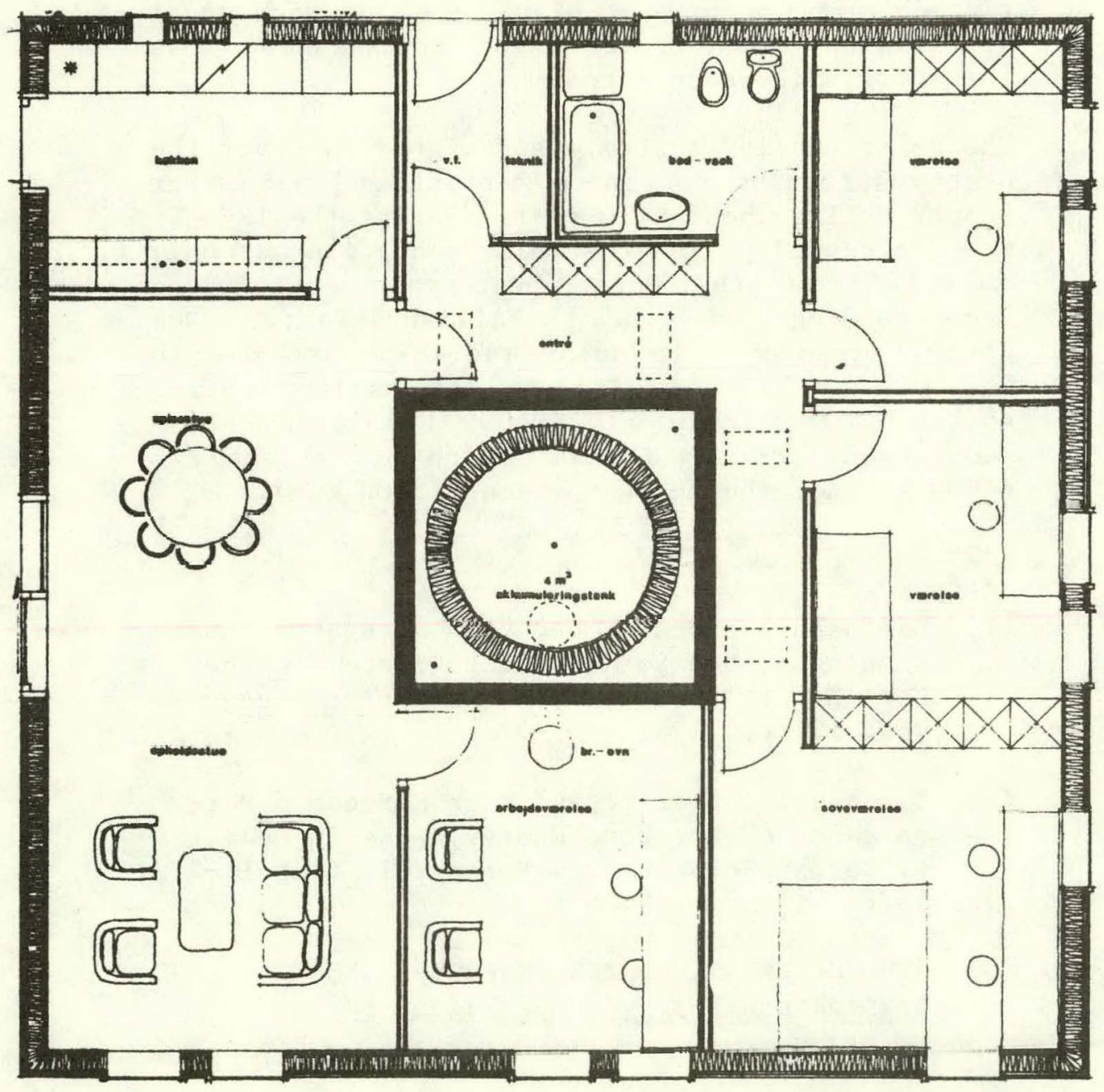

Figure 13 


\section{TEAM KUDU LOW ENERGY HOUSE at SKIVE, DENMARK}

A. DESCRIPTION

INTRODUCTION

In 1977 the trade council in Skive arranged a competition for the design of low-energy onefamily houses.

Twenty-three different projects were received and nine of these were selected for construction on one site in Skive.

All the projects have energy conservation measures and seven of the nine selected houses have solar energy systems for heating and hot water supply. Some of the solar systems are combined with heat pumps, and the project described here has a combination of solar and wind energy systems.

The house was designed and constructed by a team consisting of architect Finn Strabo, Consulting Engineer Torben V. Esbensen and Superfos Glasuld $\mathrm{A} / \mathrm{S}$.

The intention was to design a house in which it would be possible to systematically supply different energy systems without disturbing the plan arrangement and the architecture.

In other words, a flexible house with regard to the energy supply.

DESIGN OF BUILDING

The floor area of the house is $150 \mathrm{~m}^{2}$, exclusive of space for heat storage. The basis of the plan arrangement is the square. The center of the house is a reinforced concrete construction used as the enclosing wall for a storage tank of 4 $\mathrm{m}^{3}$.

The exterior wall structure is of light, glued sandwich panels with a core of mineral wool (thickness $235 \mathrm{~mm}$ ). The elements are insulating and at the same time, the load bearing construction of the house. Plywood flanges are glued to the core layer. These prefabricated elements, which were also used in the Zero Energy House at the Technical University of Denmark, were deve1oped by Superfos Glasuld. 
The roof is constructed as a severed pyramid with a solar collector of $12 \mathrm{~m}^{2}$ integrated in the south-facing part of the roof. The tilt of the solar collector is $20^{\circ}$. Windows that can open have 2 layers of glass, and windows that cannot open have 3 layers of glass. All the windows have insulating shutters inside.

The exterior of the house is sheathed with an impregnated wood.

\section{ENERGY CONSERVATION MEASURES}

The components in the house are insulated to the following $k$-values:

Exterior Wa11

(235 mm of mineral wool); $k=0.17 \mathrm{~W} / \mathrm{m}^{2} \times{ }^{\circ} \mathrm{C}$.

Roof

(300 mm of mineral wool): $k=0.14 \mathrm{~W} / \mathrm{m}^{2} \mathrm{x}{ }^{\circ} \mathrm{C}$

Floor : $\mathrm{k}=0.19 \mathrm{~W} / \mathrm{m}^{2} \mathrm{x}{ }^{\circ} \mathrm{C}$

Windows (2-layer of glass: $\mathrm{k}=2.8 \mathrm{~W} / \mathrm{m}^{2} \mathrm{x}{ }^{\circ} \mathrm{C}$

Windows (3-layer of glass: $k=1.8 \quad \mathrm{~W} / \mathrm{m}^{2} \mathrm{x}{ }^{\circ} \mathrm{C}$

Insulating shutters : $\mathrm{k}=0.7 \mathrm{~W} / \mathrm{m}^{2} \mathrm{x}{ }^{\circ} \mathrm{C}$

The house is very air-tight; therefore, it is necessary to install a mechanical fresh-air ventilation system, which also distributes the heat in the house.

The Infiltration has not yet been measured, but it is expected to be about 0.2 air changes per hour.

The fresh air ventilation is $180 \mathrm{~m}^{3} / \mathrm{h}$ corresponding to 0.5 air changes per hour. This system is provided with heat recovery equipment with an efficiency of about $60 \%$.

SOLAR AND WIND ENERGY SYS'IEM

The system consists of a $13 \mathrm{~m}^{2}$ flat-plate solar collector with one layes of usdluary glass, a wind rotor with a sweep area of $25 \mathrm{~m}^{2}$, and a water storage tank of $4 \mathrm{~m}^{3}$.

An electric water heater is used as auxiliary heat supply.

The rotor has five vertical molded fiberglass h1ades each five meters long and 0.35 meters wide. The blades are adjusted according to the wind direction by means of a vane and the rotor can thus start at wind speeds as low as approximately $2 \mathrm{~m} / \mathrm{s}$. 
The rotor is equipped with a storm safety device which consists of a small spring-loaded vane perpendicular to the large vane. When wind speeds exceed approximately $10 \mathrm{~m} / \mathrm{s}$, the spring between the two vanes is affected, so that the large vane, and with it, the wings are turned out of the wind direction.

It is a slow-rotation type (approximately 12 revolutions/min. at $10 \mathrm{~m} / \mathrm{s}$ wind speed). It is noiseless and therefore well suited to use in closely built areas. But the yield is not nearly as great as that of fast-running, and therefore noisy rotors.
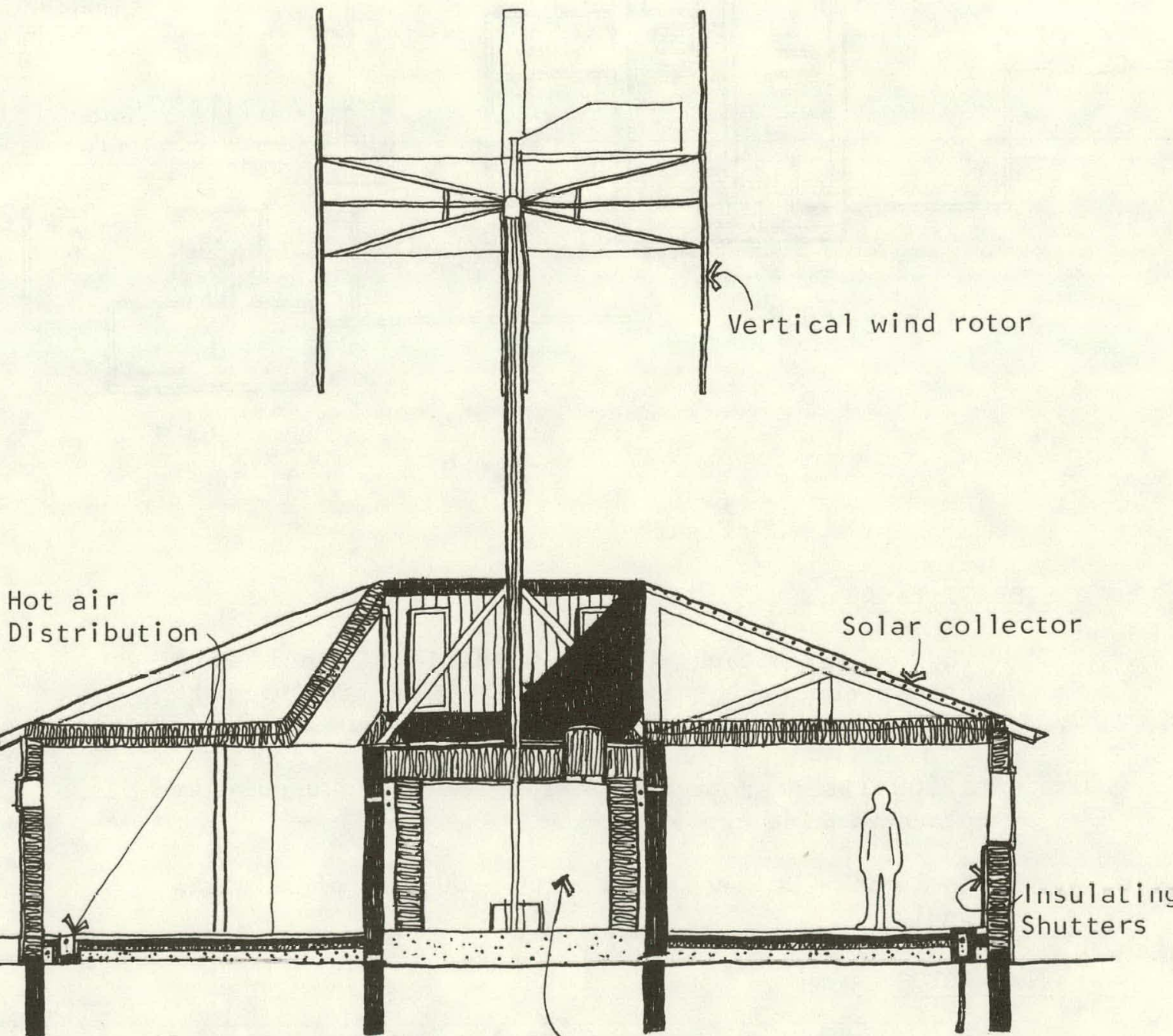

Storage tank

with water brake

Figure 14

$-29-$ 


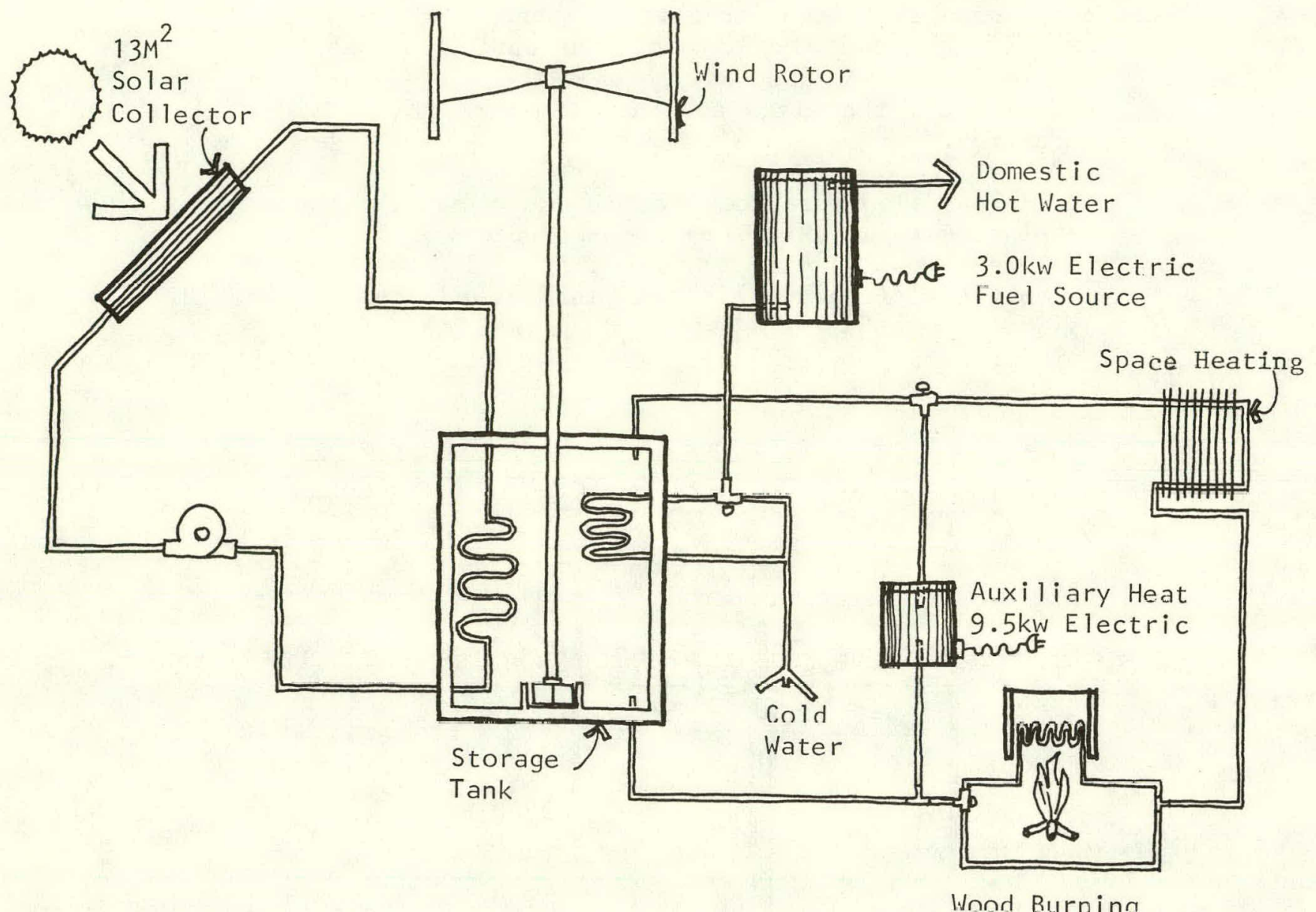

Figure 15

STORAGE TANK

The storage tank is a cylindrical steel tank placed centrally in the house. The greater part of the heat loss will help heat the house.

A 200 liter storage tank for hot water supply is placed inside the $4 \mathrm{~m}^{3}$ tank.

The tank is insulated with $200 \mathrm{~mm}$ of mineral wool.

WIND ROTOR

The wind rotor, which is positioned centrally on the house, over the storage tank, is a new type developed by Danish Wind Power Industry. 


\section{WATER BRAKE}

Since the wind rotor is a slow-rotation type, it is perhaps better suited to direct heat production than to electricity production.

The wind rotor in the Team Kudu house drives a water brake placed in the accumulator tank directly under the rotor.

The water brake has a diameter of $0.45 \mathrm{~m}$ and it consists of a star-shaped paddle wheel which creates frictional heat when it rotates in the water tank. The water brake is geared at $1: 15$. With wind speeds of $10 \mathrm{~m} / \mathrm{s}$, the wind rotor rotates 12 times per minute, and the water brake rotates 180 times per minute, to produce about $1.2 \mathrm{~kW}$.

This yield is not satisfactory and Danish Wind Power Industry is working to improve the rotor so that the number of revolutions per minute increases and with this, the yield is increased.

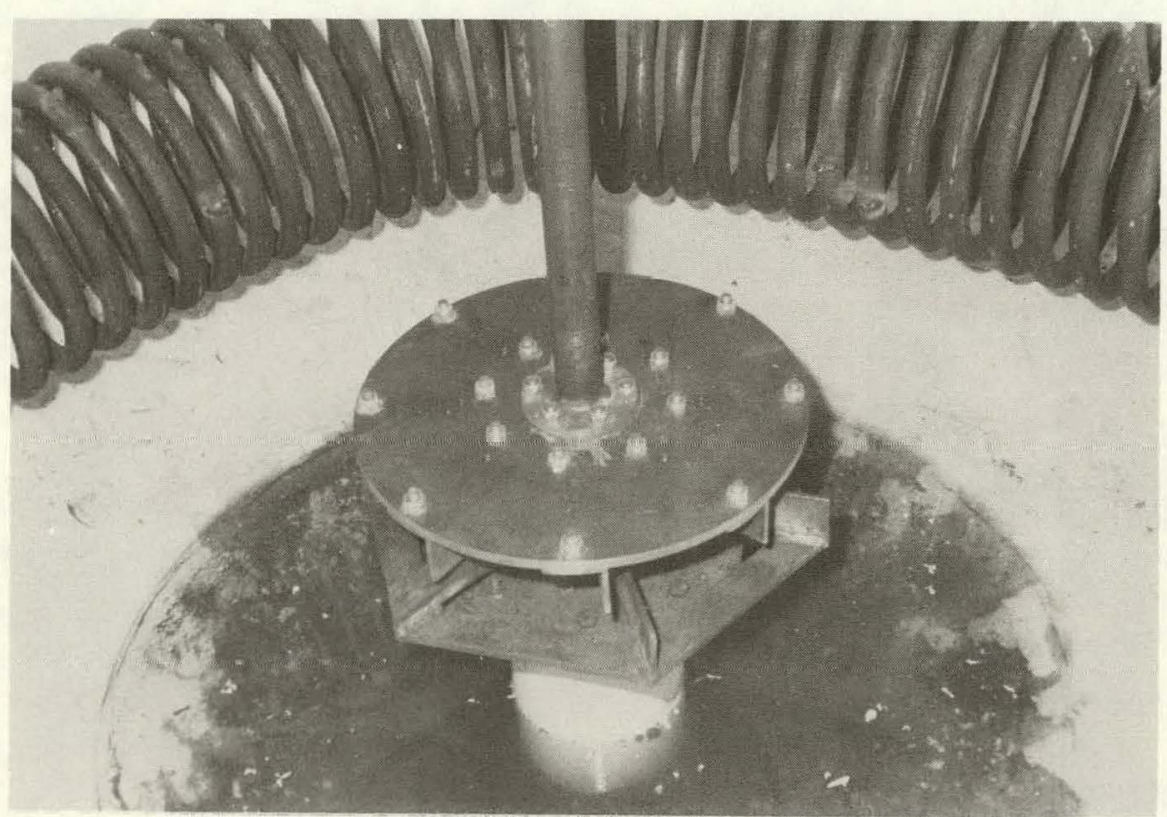

Figure 16

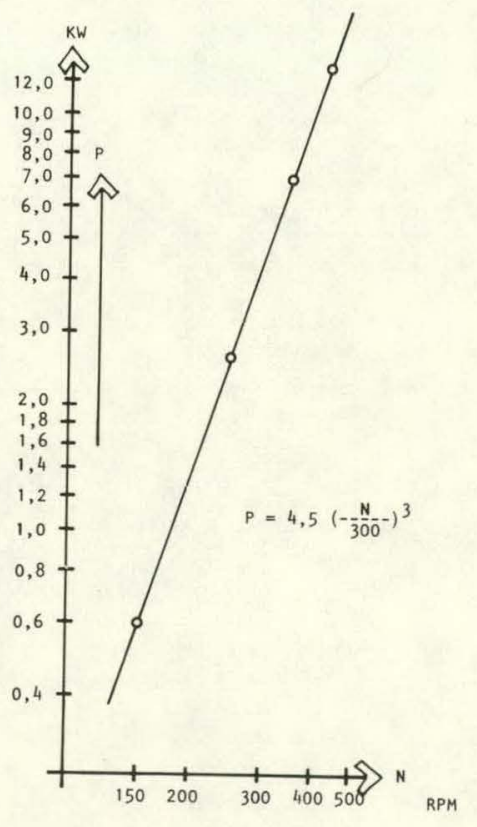

Calibration curve for the water brake 
B. OPERATIONAL AND PERFORMANCE RESULTS

CALCULATED ENERGY BALANCE

The design heat load is $4.7 \mathrm{~kW}$.

The heat requirement has been calculated to 6,000 $\mathrm{kWh}$ for space heating and $4,500 \mathrm{kWh}$ for domestic hot water. This compares well with a typical, well insulated one-family house in Denmark, on which the total heat requirement is $20,000 \mathrm{kWh}$ per year.

The solar and wind energy systems are able to supply about $3,500 \mathrm{kWh}$ per year corresponding to $1 / 3$ of the total heat requirement.

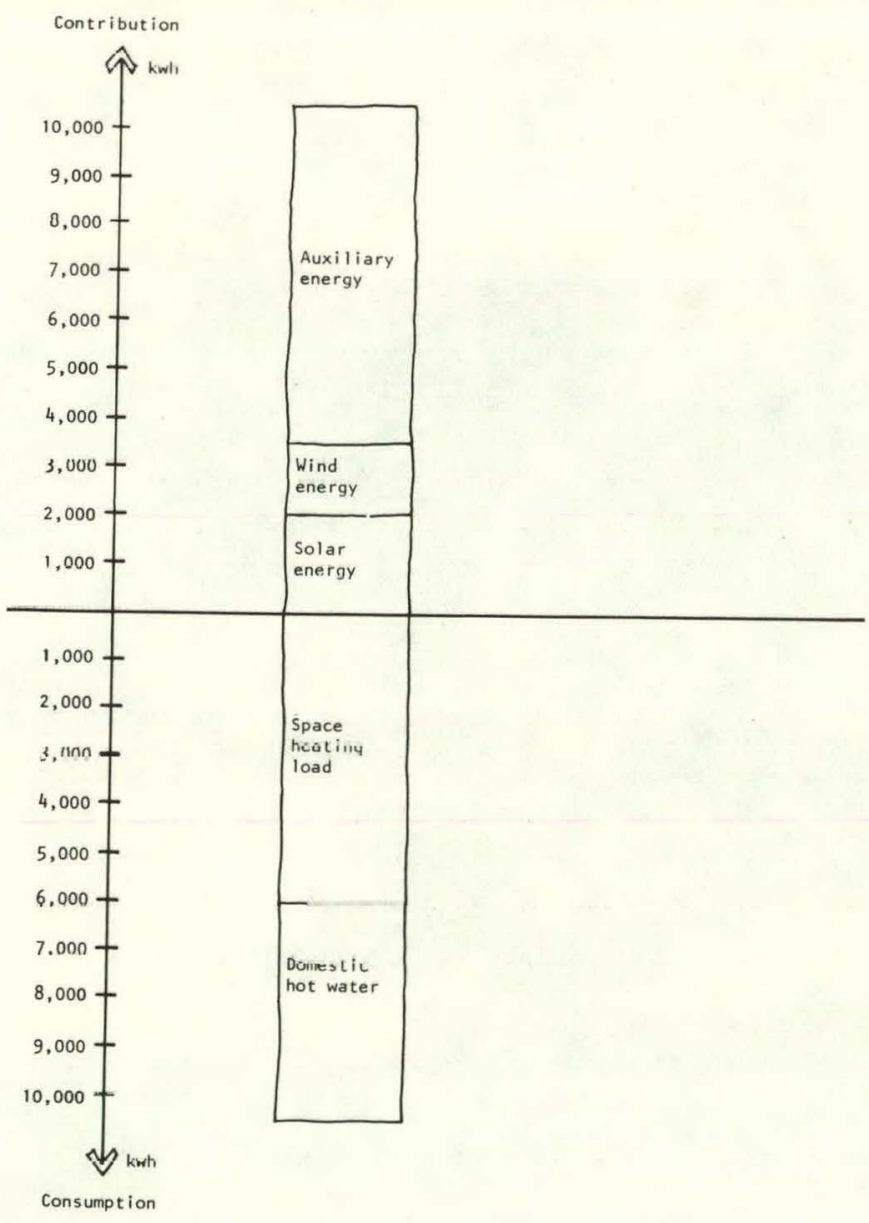

Figure 18 
ECONOMICS

The solar collector, wind rotor and storage tank cost 45,000 Danish Crowns ( $\$ 8,400$ US).

The additional heating and ventilating system also cost 45,000 Danish Crowns. (\$8,400 US).

The cost of the total heating system was 90,000 Danish Crowns ( $\$ 16,000$ US), or 65,000 Danish Crowns $(\$ 12,000$ US) more than the cost of a conventional oil heating system.

The solar and wind energy systems give a yearly energy saving of $5200 \mathrm{kWh}$.

The additional investment of 65,000 Danish Crowns ( $\$ 12,000$ US) means, thus, a yearly energy saving of $8,700 \mathrm{kWh}(1,100$ liters of oil).

\section{ADDITIONAL INFORMATION}

Additional information may be obtained from the paper: "Design of a Low-Energy House in Denmark Heated by a Combination of Solar and Wind Fnergy" by Torben V. Esbensen and Finn Strabo.

The paper is presented in the proceedings from "Internationa1 Solar Energy Congress, New Delhi, India, 1978" and "lst Solar Energy Forum, Hamburg, FRG, $1977 "$. 


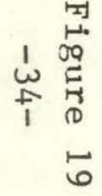

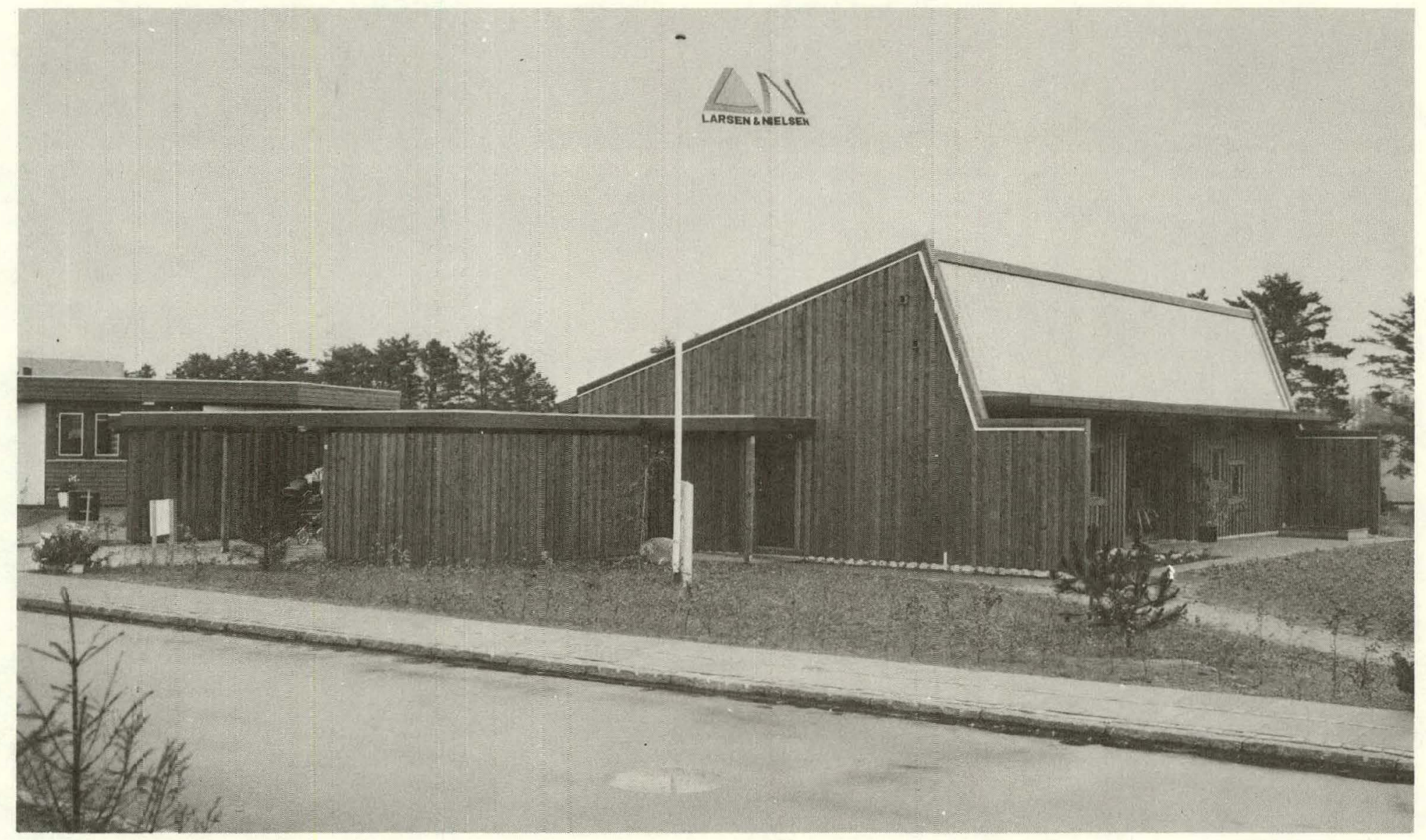




\section{THE LN LOW ENERGY HOUSE at SKIVE, DENMARK}

\section{A. DESCRIPTION}

\section{INTRODUCTION}

The LN low-energy house is one of the nine low-energy houses which were built on a common site in Sk1ve during the summer of 1977.

The experimental house, which was built by Larsen \& Nielsen Enterprises $\mathrm{A} / \mathrm{S}$, is the first result of the developmental work with low-energy systems for Larsen \& Nielsen's series building projects.

The purpose of the experimental house is to demonstrate that it is already possible to build a spacious and practical one-family house, which for heating purposes is independent of external energy supply (with the exception of energy to run heat circulating equipment and heat pumps).

\section{DESIGN OF THE BUILDING}

The house, which has a living area of $130 \mathrm{~m}^{2}$ is divided into a parents' and children's section with kitchen/a11-purpose room between.

The mechanical room, where all the components for the house's heating system are collected, is effectively screened to protect the other rooms against noise.

Ceilings, partitions, and the interior part of the exterior wall structure are of Gipsotex-multielement, a sandwich construction with $13 \mathrm{~mm}$ gypsum board on both sides of a polyurethane-foam core of high insulation capacity. The exterior walls are clad on the outer side with iüpregnated woud.

The elements have a height of $2.4 \mathrm{~m}$ and a length of up to $16 \mathrm{~m}$.

The overhang over the southern facade prevents undesired heating of the rooms during the summer, but permils solar incldence through the windows during the winter.

The solar collector of $29 \mathrm{~m}^{2}$, comprises the entire southern roof surface, which has a tilt of $70^{\circ}$ from horizontal. 
The components of the house are insulated to the following $k$-values:

Exterior Wa11

(100 mm polyurethane foam): $k=0.31 \mathrm{~W} / \mathrm{m}^{2} \mathrm{x}{ }^{\circ} \mathrm{C}$

Ceiling ( $100 \mathrm{~mm}$ mineral

wool plus $100 \mathrm{~mm}$ poly-

urethane foam):

Floor:

Stationary windows:

(three-layer glass)

Windows which can be opened

(two-layer glass):

$\mathrm{k}=0.19 \mathrm{~W} / \mathrm{m}^{2} \times{ }^{\circ} \mathrm{C}$

$\mathrm{k}=0.31 \mathrm{~W} / \mathrm{m}^{2} \mathrm{x}{ }^{\circ} \mathrm{C}$

$\mathrm{k}=1.8 \mathrm{~W} / \mathrm{m}^{2} \times{ }^{\circ} \mathrm{C}$

$\mathrm{k}=3.0 \mathrm{~W} / \mathrm{m}^{2} \times{ }^{\circ} \mathrm{C}$

Because of the large size of the exterior wall elements, there are few joints in the house, and it is, therefore, very air-tight. The house is equipped with a mechanical fresh-air system with heat recovery. The quantity of fresh air is 140 $\mathrm{m}^{3} / \mathrm{h}$ corresponding to an air change of 0.45 times per hour.

\section{SOLAR HEATING SYSTEM}

Solar heat and waste heat from waste water (washing machine, showers, sinks) in connection with a heat pump, supply the space heating for the house.

The domcatic hot water is provided during tie summer totally by means of solar heat, during the winter by waste heat from the exhaust air via yet a nother heat pump.

SOLAR COLLECTOR

The solar collector consists of 16 flat-plate panels with tubes integrated in the steel plate. The combined area is $29 \mathrm{~m}^{2}$.

The covering layer is of patterned glass with a granulated surface (no mirror effect).

'l'he absorber is insulated on its back side with $.100 \mathrm{~mm}$ polyurethane foam (Multielement).

During the winter pump PI circulates hot water from the solar collector to the storage tank. 
The heat storage consists of two series-joined tanks with combined volume of $11 \mathrm{~m}^{3}$.

Ali waste water from washing and bathing installations is sent to the storage tank, where it is sent out to the sewer system.

\section{SPACE HEATING}

The house is heated by a hot air system. The air is heated with hot water via pump P2 either from the solar collector or from the storage tank.

If the temperature in the storage tank is not sufficiently high, heat pump 1 starts, this takes heat from the storage tank via pump P3.

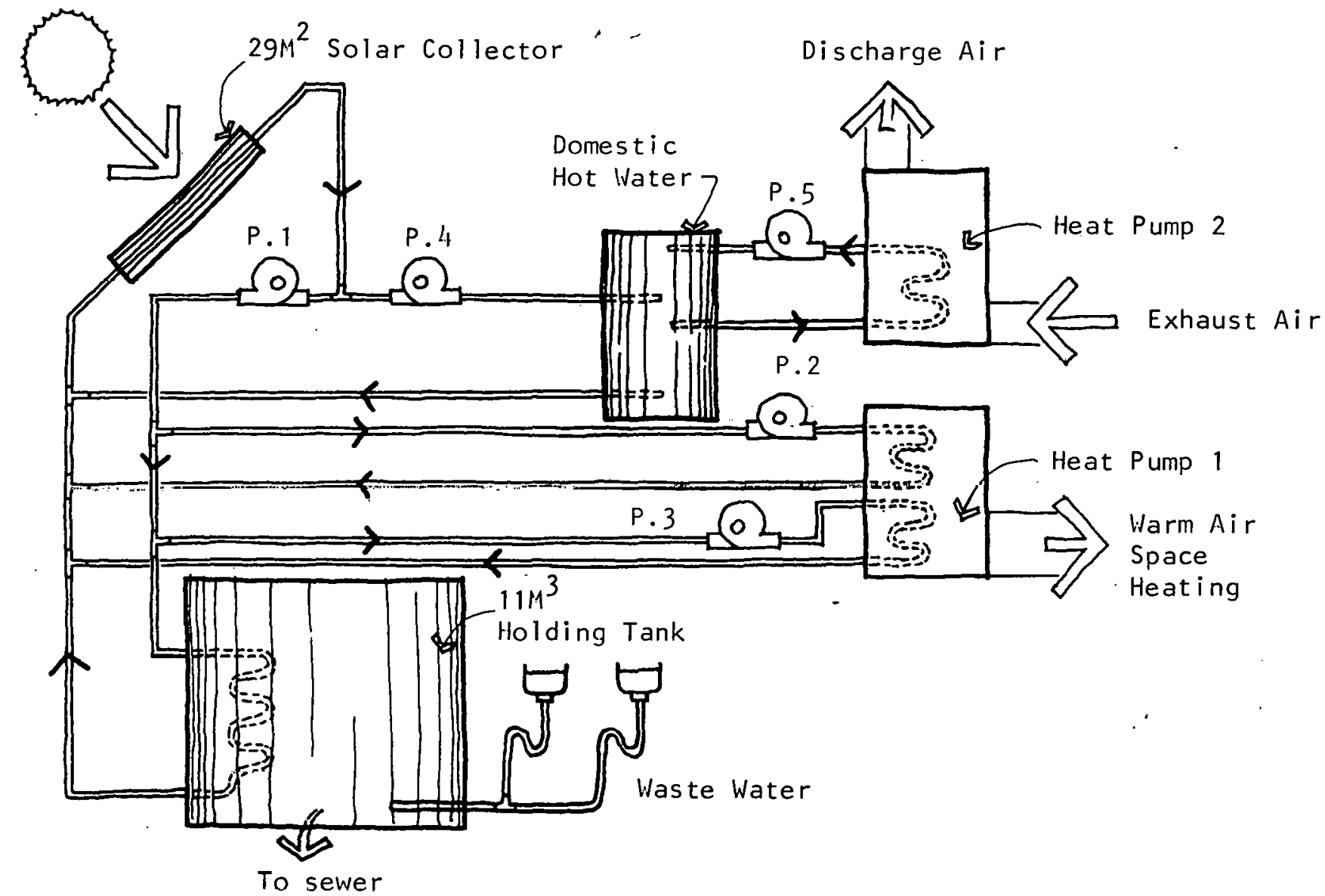


During the summer, the hot water tank is heated by the solar collector via pump $\mathrm{P} 4$.

During the winter the hot water tank is heated by the heat pump HP2 via the pump P5. The heat pump takes the heat from the exhaust air in the freshair system

B. OPERATIONAL \& PERFORMANCE RESSULTS

CALCULATED ENERGY BALANCE

Heat requirement for space heating $7800 \mathrm{kWh}$

lleat requirement fur dumeslle hot water TOTAL

Solar heat and the heat pump system are designed to meet the entire heat demand of $12,300 \mathrm{kWh}$.

In addition, electric energy supply is required for heat pumps, circulation pumps and ventilators.

Heat pump HPl for space heating $2000 \mathrm{kWh}$ Heat pump HP2 for domestic hot water $750 \mathrm{kWh}$ Circulation pumps and ventilators ENERGY SUPPLY TOTAL $\frac{900 \mathrm{kwh}}{3650 \mathrm{kWh}}$

PERFORMANCF. RF.SIIT.TS

The house has been inhabited by a family since. August, 1977. The monitoring program, headed by the Technological Institute in Copenhagen, was started in october, 1978. The family had notcd an unsatisfactory distribution of heat in the house.

The house is heated by a1r, which is blown into all roome at the same temperature via a common duct in the floor. When there was a great heat supplement in the living room, for example, due to solar incidence through the south-facing windows, the common air-entry-temperature was lowered automatically, which results in temperatures which were too low in the north-facing rooms. The problem has now been solved by removing the control thermostat from the living room to the 
common duct for exhaust air. The common airentry-temperature is now controlled on the basis of the mean temperature in the house.

The used air is exhausted through the bathroom, which is heated in this manner only. This has proved to give inadequate heat, and it has therefore been necessary to install electrical floor heating elements supplied from the heat pump HP2.

\section{ECONOMICS}

The investment in the low-energy house with solar heat and heat pump system is compared with the investment in an equivalent house which is electrically heated and a house which is heated by an oil furnace.

\begin{tabular}{|c|c|c|c|}
\hline & Investment & $\begin{array}{c}\text { Energy } \\
\text { Consumption } \\
\text { Per Year } \\
\end{array}$ & $\begin{array}{l}\text { Energy } \\
\text { Expenditures } \\
\text { per Year }\end{array}$ \\
\hline $\begin{array}{l}\text { Low-Energy } \\
\text { House }\end{array}$ & US $\$ 105,000$ & $\begin{array}{l}3650 \mathrm{kWh} \\
\text { Qus } \$ 0.05\end{array}$ & US $\$ 185$ \\
\hline $\begin{array}{l}\text { Electri- } \\
\text { cally } \\
\text { Heated } \\
\text { House }\end{array}$ & US\$ 86,000 & $\begin{array}{l}16000 \mathrm{kWh} \\
\text { dUS } \$ 0.05\end{array}$ & US $\$ 800$ \\
\hline $\begin{array}{l}\text { Oil- } \\
\text { Heated } \\
\text { House }\end{array}$ & US\$ 90,000 & $\begin{array}{l}2700 \text { liters } \\
\text { of oil } \\
\text { Qus } \$ 0.18\end{array}$ & US $\$ 485$ \\
\hline
\end{tabular}

\section{ACKNOWLEDGEMENT}

Information for this section was obtained from the paper: "The LN Solar/Heat Pump House at Skive, Denmark" by A.-Eggers-Lura.

The paper was presented at the Second International Solar Forum in Hamburg, July 12-14, 1978.

Further information may be obtained from Larsen \& Nielsen Enterprise A/S, Datavej 44, DK-3460 Birkerod, Denmark. 


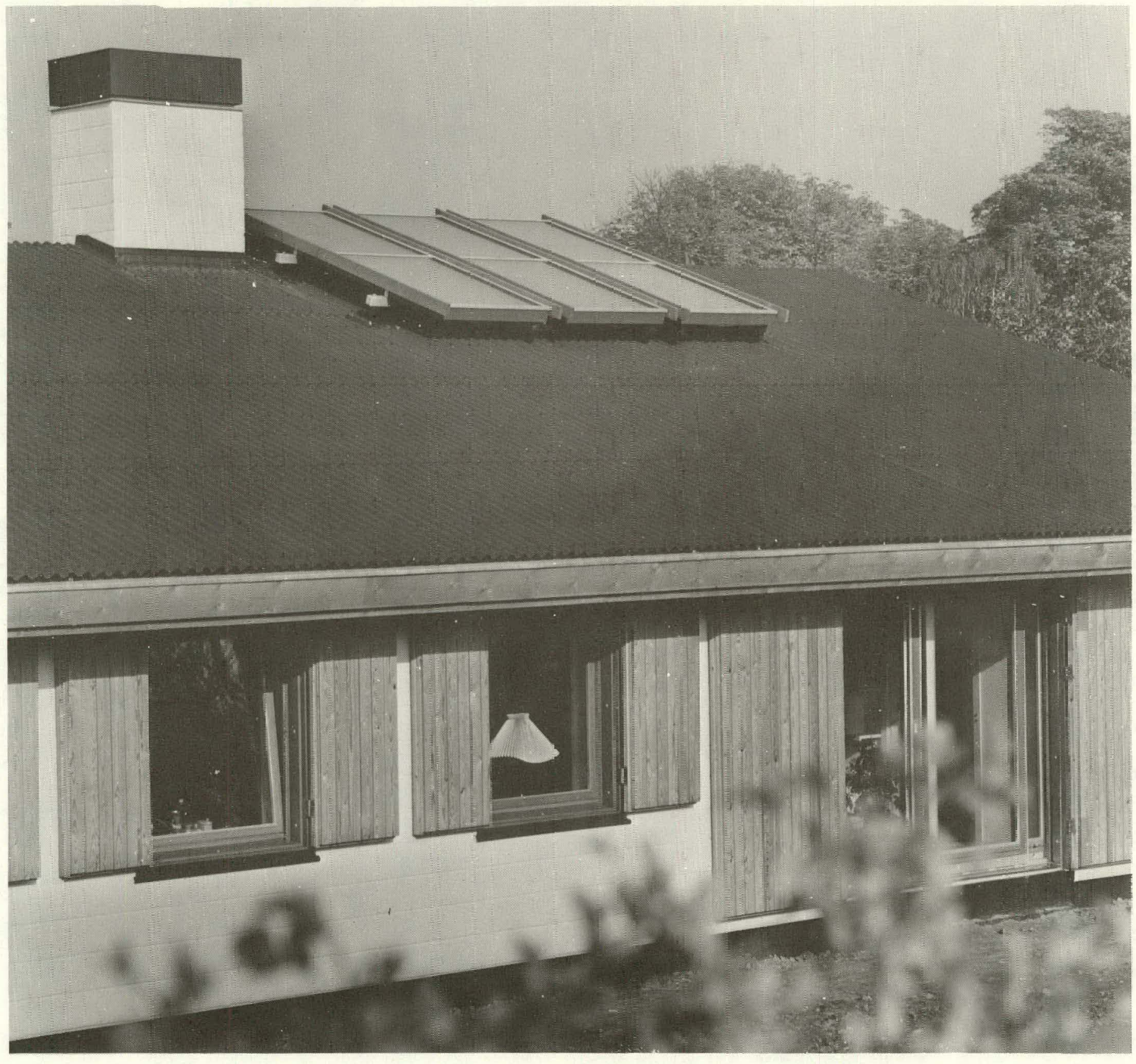




\section{LOW ENERGY HOUSE at HJORTEKAER, DENMARK}

\section{A. DESCRIPTION}

In the summer of 1978 , six low-energy houses were built at a common site in Hjortekaer near the Technical University of Denmark.

The low-energy house project was a cooperative effort of the Technical University of Denmark and six private firms. The project was supported by the Ministry of Commerce as a link in the government's program for expansion of Danish energy research.

A low-energy house in this project is understood to be a one-family house with a living area of approximately $120 \mathrm{~m}^{2}$ and with an energy supplement from outside sources of maximum 5000 kWh per year for space heating and domestic hot water.

The low-energy consumption of the houses is achieved by means of extra insulation, heat recovery from the exhaust air, use of alternative energy sources, and use of free heat through heat storage in heavy building structures.

In this section one of the six houses described is the $\mathrm{H}+\mathrm{H}$ house, which was built by $\mathrm{H}+\mathrm{H}-$ Industry with Bertel Udsen as architect, and Johs. Jorgensen, Inc. as consulting engineers.

\section{DESIGN OF THE BUILDING}

All principal ruoms in the housc arc oriented toward the south, so that the windows can function as passive solar collectors. The ceilings slope with the roof surface, so that the heat supplement 
through the windows can be stored in the high, heavy interior walls without uncomfortable overheating of the air in the living zone.

The exterior cavity walls are of two layers of 150 $\mathrm{mm}$ lightweight concrete block enclosing a hollow core filled with $200 \mathrm{~mm}$ mineral wool.

The interior partition walls are of $100 \mathrm{~mm}$ lightweight concrete block. Windows and exterior doors have two-layer glass equipped with insulating shutters for night use.

\section{ENERGY CONSERVATION ARRANGEMENTS}

The components in the house are insulated to the following $k$-values:

Exterior walls $(200 \mathrm{~mm}$ mineral wool plus $300 \mathrm{~mm}$

lightweight concrete): $\quad k=0.15 \mathrm{~W} / \mathrm{m}^{2} \mathrm{x}{ }^{\circ} \mathrm{C}$

Floors :

$$
\mathrm{k}=0.18 \mathrm{~W} / \mathrm{m}^{2} \times{ }^{\circ} \mathrm{C}
$$

Roof ( $400 \mathrm{~mm}$ mineral

woo1):

$$
\mathrm{k}=0.10 \mathrm{~W} / \mathrm{m}^{2} \times{ }^{\circ} \mathrm{C}
$$

Since the house is very tightly constructed, it is equipped with a ventilation system with heat recuvery.

There is, in addition, heat recovery from waste water from bath and sinks via a heat exchanger, where the domestic cold water is pre-heated.

The house is heated by means of a forced-air system, in this way the heavy construction can be used to greatest advantage.

When there is solar incidence through the windows, the thermally fast-acting, air-heat system stops, and solar heat accumulates in the heavy structure. In this manncr, uncomfortable uver-heating of the rooms is avnided, 


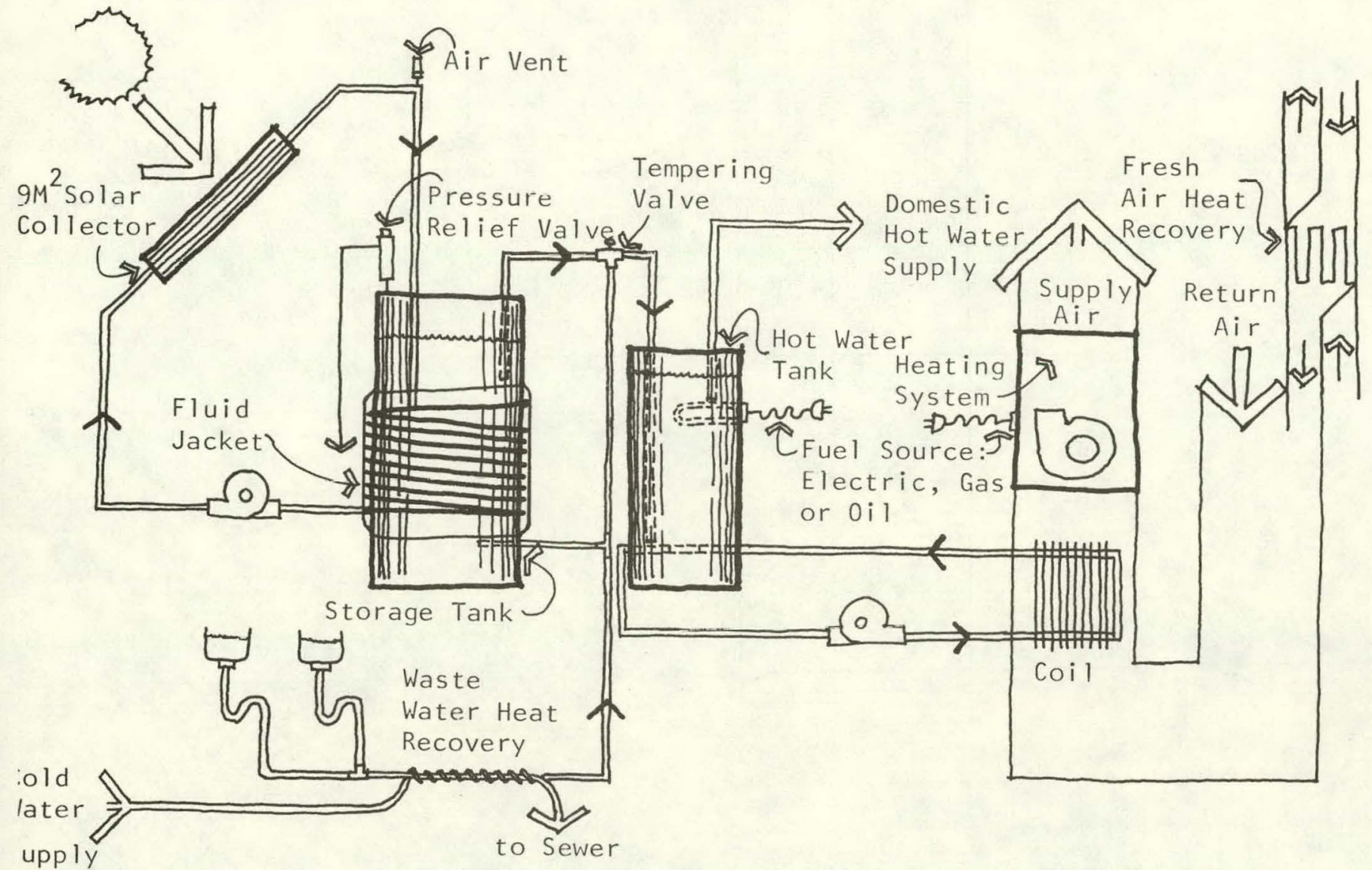

Figure 22

\section{SOLAR HEATING SYSTEM}

The house is equipped with a small solar-heat system for domestic hot watcr.

The solar collector of $9 \mathrm{~m}^{2}$ is placed on the south-facing roof with a tilt of $20^{\circ}$.

The heat storage tank is an ordinary hot water tank, in which the solar collector fluid circulates in the exterior jacket. In the tank 1tself is domestic water.

Before the cold water reaches the heat storage tank it is pre-heated in the waste water's heat recovery unit. 


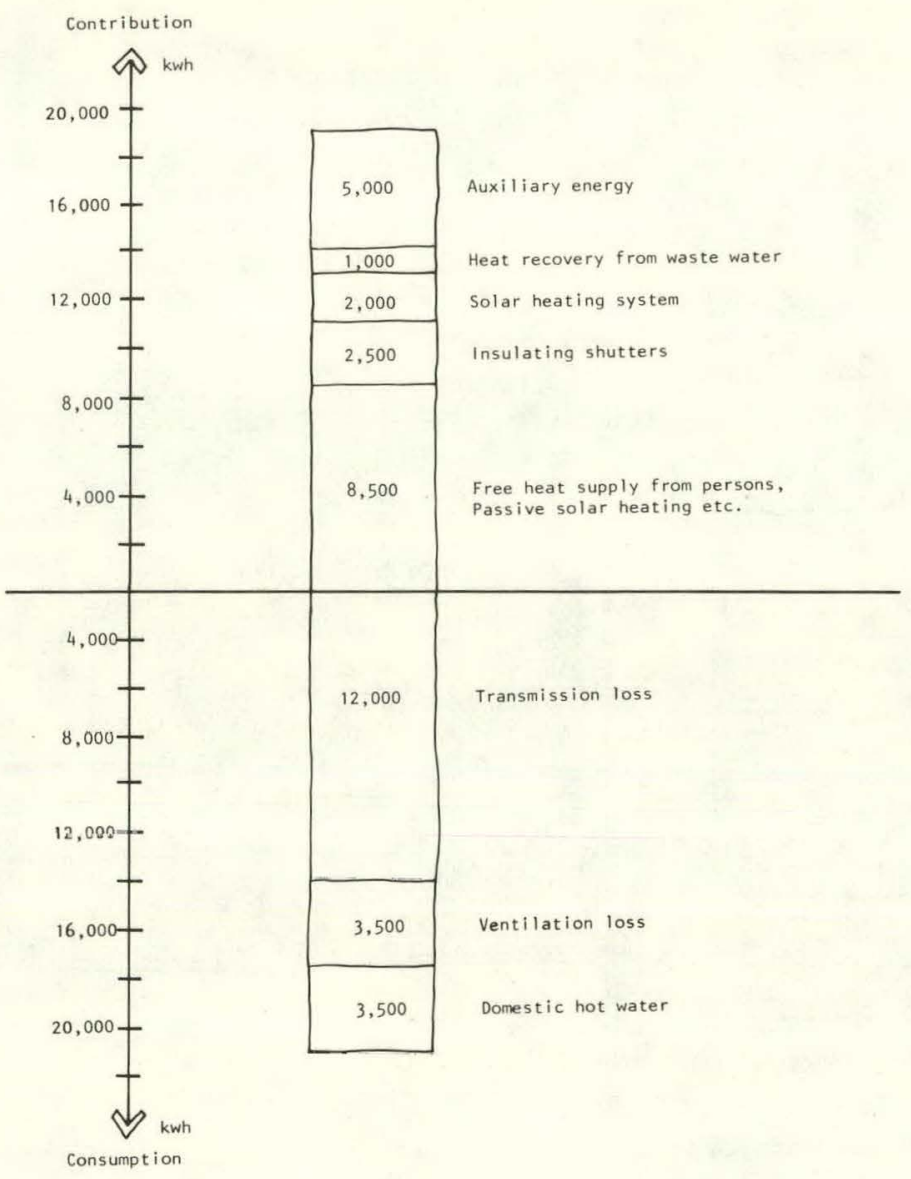

Figure 23

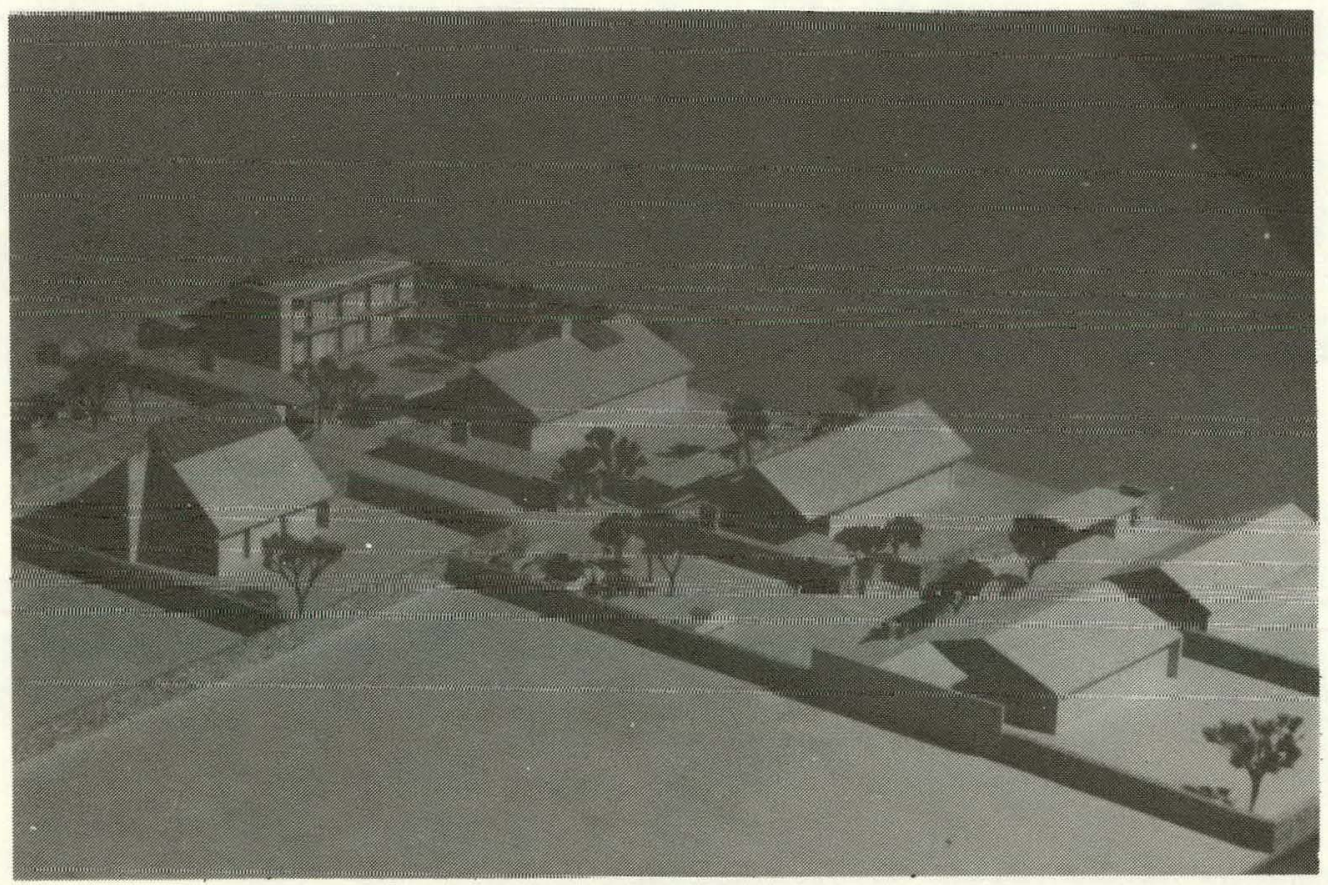

Figure 24

$-44-$ 
During the summer the heat storage tank water can reach a temperature of $90^{\circ} \mathrm{C}$, and, in order to avoid scalding, it is mixed with cold water before it reaches the boiler.

In winter, the temperature in the heat storage tank is not sufficient, and heat is added to the water by the boiler.

\section{ADDITIONAL INFORMATION}

Furller information about the six low-energy houses in Hjortekaer may be obtained from the Thermal Insulation Laboratory, Technical University of Denmark, Building 118, DK-2800, Lyngby, Denmark. 


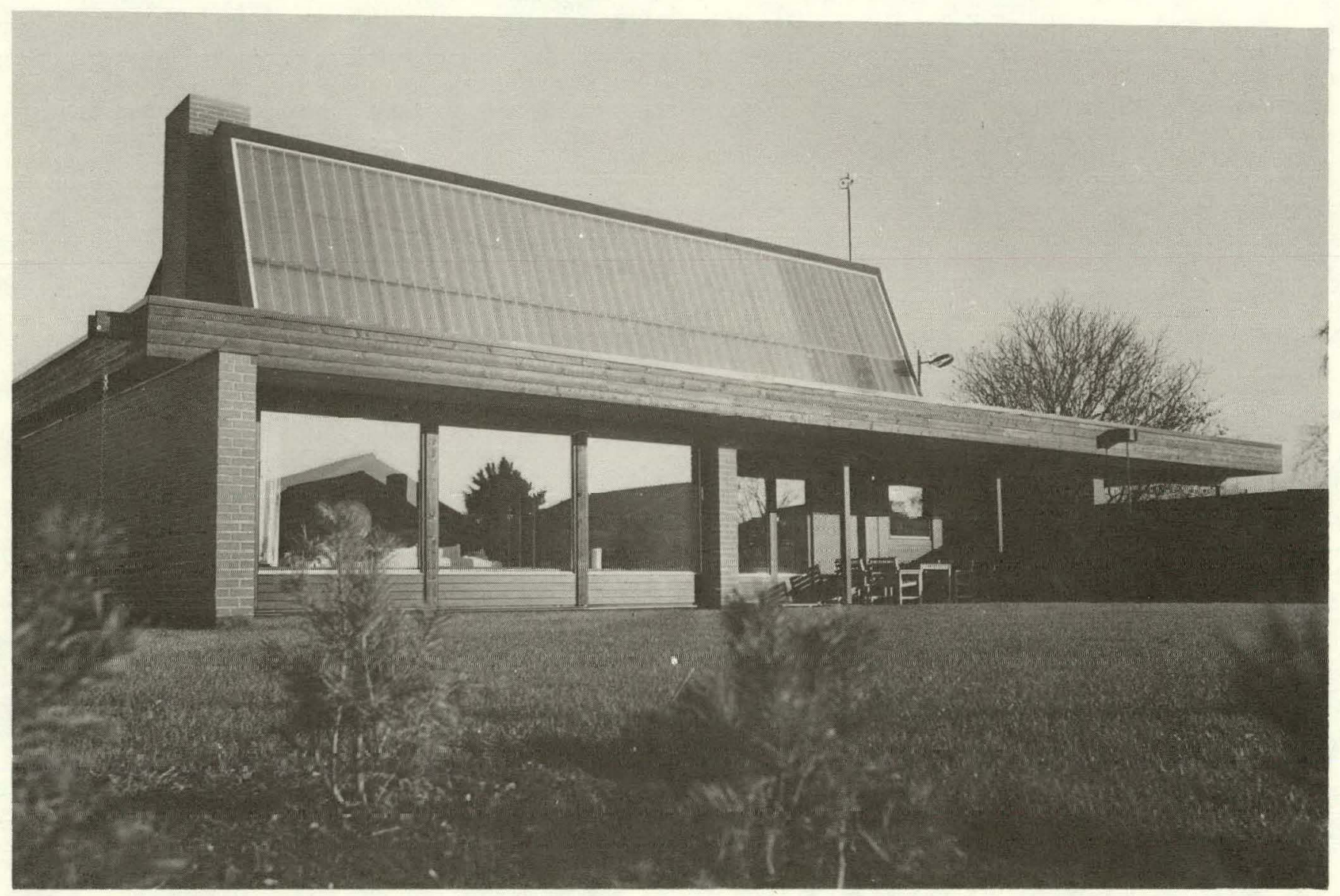

Figure 25

-46- 


\section{THE TERMOROC LOW ENERGY HOUSE at LIMHAMN, SWEDEN}

A. DESCRIPTION

\section{INTRODUCTION}

The Termoroc house was built in 1975 by the firm Tekno Term Systems $A B$ in Malmo. The object was to build an experimental house with energy-saving measures, so that the yearly energy consumption for heating and domestic hot water would not exceed a maximum of $50 \%$ of the energy consumption in a comparable traditionally insulated house.

\section{CLIMATIC CONDITIONS}

The house is located in Limhamn, Sweden at a latitude of $55^{\circ}$.

The mean annual number of sunshine hours is 1738 .

The mean ambient temperature is $8.0^{\circ} \mathrm{C}$ and the annual number of degree days is 3020 calculated with $17^{\circ} \mathrm{C}$ as the base indoor temperature.

DESIGN OF THE BUILDING

The Termoroc house has a floor area of $242 \mathrm{~m}^{2}$, of which $150 \mathrm{~m}^{2}$ is living space distributed in three levels which are staggered in relation to each other by $1 / 2$ story.

The window area is $23 \mathrm{~m}^{2}$, of which $16 \mathrm{~m}^{2}$ face south. These windows are equipped with a horizontal overhang which permits solar incidence through the windows during the winter, and screens against solar incidence during the summer.

The house is equipped with $52 \mathrm{~m}^{2}$ of solar collectors, which comprise the entire southern roof surface. The solar collector structure has been made architecturally attractive by building the glass surface of 52 self-bearing construction glass members (U-beam glass) $0.25 \mathrm{~m}$ wide and $4.0 \mathrm{~m}$ long. These glass members are mounted vertically and form a continuous glass wall without mullions.

\section{VENTILATION}

During construction, the house was very carefully sealed. Those joints which ordinarily cause leaks between parts of the building, have been specially supervised. 
The ventilation system operates as natural ventilation with intermittent forced ventilation.

Normally the system operates on the natural ventilation principle, i.e., a supply of air enters via the leaks which exist in the house despite all the measures taken. Air flows out again via exhaust air ducts, being extracted from the kitchen, bathroom, WC and laundry. The ventilation rate is automatically kept constant at about 0.5 air changes per hour by a valve, which controls the air flow on basis of the outside temperature and wind velocity. The valve closes further, if the temperature falls and the wind velocity increases.

When the light is turned on in the bathroom, WC or laundry, or when a special switch in the kitchen is pressed, fans are started in the heat exchanger being preheated by the heat recovered from the exhaust air. The ventilation rate is now 0.8 air changes per hour, but due to the heat exchanger, the heat losses remain at the same level as for natural ventilation with a rate of 0.5 air changes per hour.

WASTE WATER OUTLET

The hot waste water from the bathroom etc. is discharged through a delayed outlet. The outlet consists of a $12 \mathrm{~m}$ long pipe of $200 \mathrm{~mm}$ diameter, which is embedded in the basement's concrete floor and has a slope of $10 \mathrm{~mm}$. The heat from the waste water pipe is absorbed by the basement floor slab reducing the heat loss from the house.

Copper pipe coils have been wrapped around the waste water pipe in order to preheat the cold inlet water.

The roof surface in front of the solar collector is covered with a layer of aluminum which reflects the sun's rays into the solar collector.

ENERGY CONSERVATION MEASURES

INSULATION

Exterior walls:

$200 \mathrm{~mm}$ mineral wool $\mathrm{k}=0.27 \mathrm{~W} / \mathrm{m}^{2} \mathrm{x}{ }^{\circ} \mathrm{C}$

Roof:

$220 \mathrm{~mm}$ mineral wool

Floor:

$\mathrm{k}=0.23 \mathrm{~W} / \mathrm{m}^{2} \times{ }^{\circ} \mathrm{C}$

$\mathrm{k}=0.10 \mathrm{~W} / \mathrm{m}^{2} \mathrm{x}{ }^{\circ} \mathrm{C}$ 
In connection with the Termoroc house different types of mobile window insulations have been developed which reduce heat loss through the windows at night. The window insulation is placed on the interior side to avoid influences from the outdoor climate and to simplify operation.

Two types of window insulation have been installed in the house:

a) Vertica11y movable window insulation of the folding type. Hidden during daytime in the window seat beneath large south-facing windows Operated by crank mechanism.

b) Vertically extending window insulation of flexible type. Runs upward in guides under the ceiling, where it is fully visible. Operated by handle at the bottom edge.

The insulation consists of $15 \mathrm{~mm}$ PUR-cellular plastic.
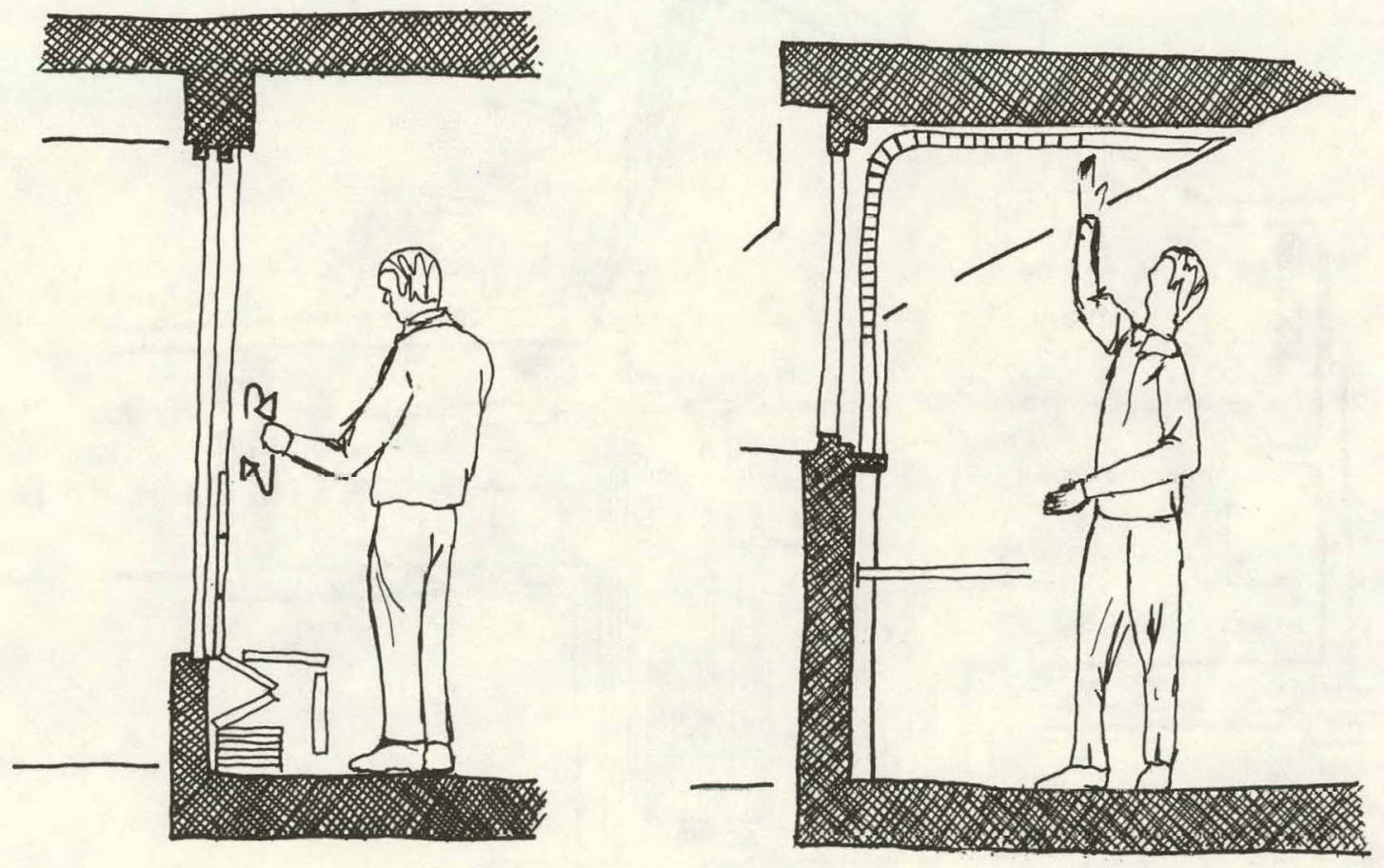

Figure 26 
Without the window insulation, the windows with three-layer glass have a k-value of $2.0 \mathrm{~W} / \mathrm{m}^{2} \mathrm{x}$ ${ }^{\circ} \mathrm{C}$. With the window insulation, the $\mathrm{k}$-value of the window assembly is $0.8 \mathrm{~W} / \mathrm{m}^{2} \mathrm{x}{ }^{\circ} \mathrm{C}$.

In addition, the window insulation is used as sunshading on winter days when the sun is low in the sky.

\section{SOLAR HEATING SYSTEM}

The solar heating system consists of $52 \mathrm{~m}^{2}$ solar collectors and a storage system with 2 tanks of $1.7 \mathrm{~m}^{3}$ each.

The collectors covering the south face of the saddle roof have a tilt of $70^{\circ}$, and they are oriented $13^{\circ}$ west of south. The collertnrs rnnsist of nonselective flat plate steel absorbers with integrated tubes.

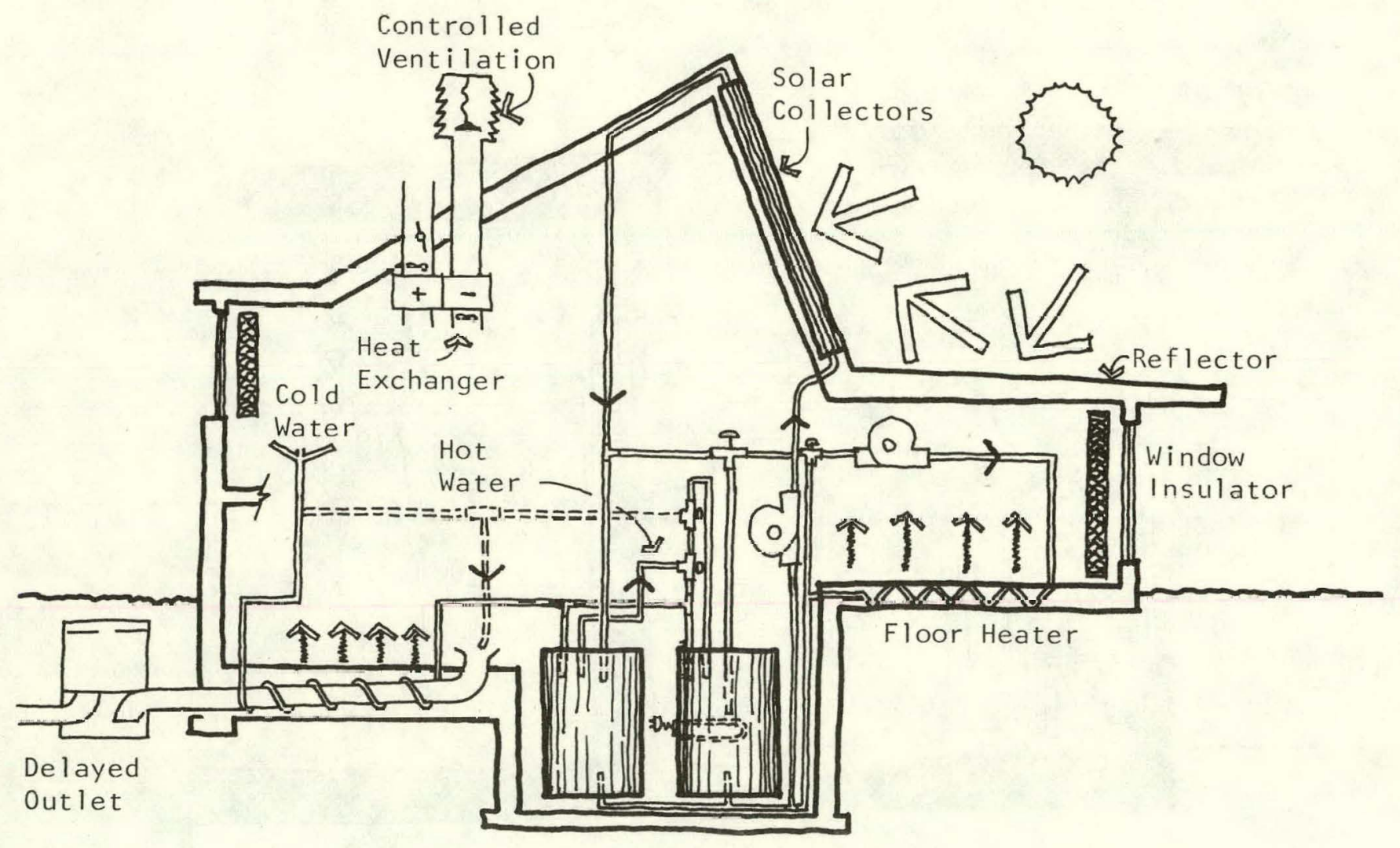


The water from the collectors flows either directly to the heat-distribution system or to the heat storage tanks.

When the water in the solar collectors becomes colder than that in the storage tank, the collectors are automatically drained. The water is drained into the tank, and nitrogen gas stored above the water surface rises and fills the solar collector protecting it against inside corrosion and damage from freezing.

When the collector again is heated by solar radiation, it is filled with water and the nitrogen gas is forced back into the tank, where it serves as expansion volume.

The collectors are also automatically drained if the temperature in the storage tank or in the collector exceeds $95^{\circ} \mathrm{C}$.

One of the tanks in the storage system is normally used for solar heat storage and the other tank is used for off-peak electric heat storage during the night. During summer both tanks can be used for solar heat storage and in extremely cold weather during the winter, both tanks can be used for over night electric heat storage.

B. OPERATIONAL \& PERFORMANCE RESULTS

MEASURED ENERGY BALANCE

The heat balance was measured in the heating season 1975/76 (October 9, 1975 - May 8, 1976).

During this period only $42 \mathrm{~m}^{2}$ of the total of 52 $\mathrm{m}^{2}$ of solar collector were in operation, as 10 $\mathrm{m}^{2}$ of the solar collector were used for special experiments.

The solar heating system supplied approximately $25 \%(5100 \mathrm{kWh})$ of the total energy used for heating and domestic hot water $(21,800 \mathrm{kWh})$. 


\begin{tabular}{|l|r|c|}
\hline $\begin{array}{l}\text { Space heating load } \\
\text { Domestic hot water load }\end{array}$ & $\begin{array}{r}19,500 \mathrm{kWh} \\
2,300 \mathrm{kWh}\end{array}$ & \\
\hline TOTAL THERMAL LOAD & $21,800 \mathrm{kWh}$ \\
\hline \hline Solar energy supply & $\begin{array}{r}5,100 \mathrm{kWh} \\
500 \mathrm{kWh}\end{array}$ & \\
Supply from delayed waste & & $\begin{array}{l}5,600 \mathrm{kWh} \\
(25 \%)\end{array}$ \\
\hline TOTAL SUPPLY & $\begin{array}{c}16,200 \mathrm{kWh} \\
(75 \%)\end{array}$ \\
\hline Auxiliary Energy Needed &
\end{tabular}




\section{ACKNOWLEDGEMENT}

Information for this section has been obtained from the report: "The Termoroc House - An Experimental Low-Energy House in Sweden" by Bengt Rosengren. Report No. 08: 1977 from the Swedish Council for Building Research. St. Gorgansgtan 66, S-11230 Stockholm. 


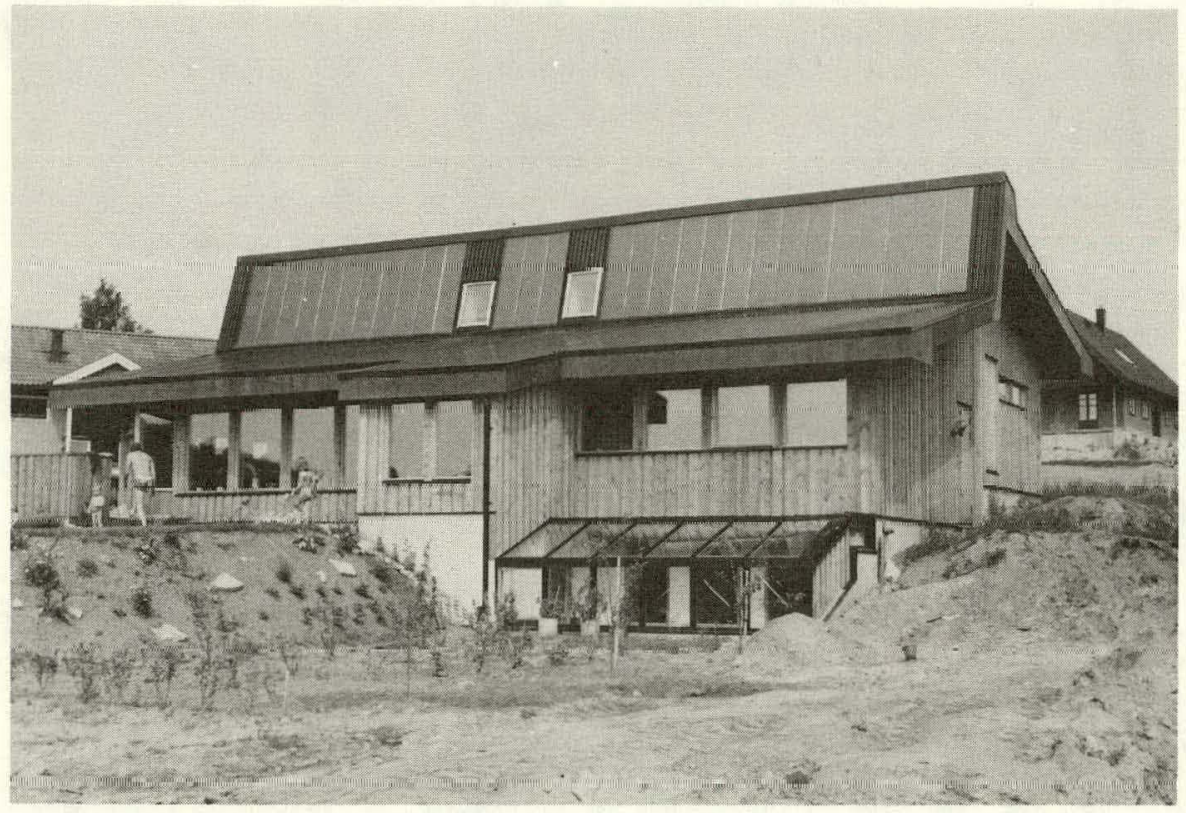

Figure 28

-54- 


\section{THE MIKKONEN LOW ENERGY HOUSE at BOLLEBYGD, SWEDEN}

A. DESCRIPTION

INTRODUCTION

The low-energy house was constructed during 1977 in Bollebygd near Gothenburg, Sweden.

The house was designed by Architect Matti Mikkonen, Bollebygd and Consulting Engineer Torben V. Esbensen, Copenhagen, Denmark.

Control measurements for the house and the energy system will take place during 1979-1980 funded by a grant from the Swedish Council for Building Research.

\section{DESIGN OF THE BUILDING}

The house has a living area of $140 \mathrm{~m}^{2}$ distributed on 1-1/2 storles. In addition there is an $80 \mathrm{~m}$ basement, which holds among other things, all the mechanical equipment.

The window area is $24 \mathrm{~m}^{2}$, of which $18 \mathrm{~m}^{2}$ face south. These windows are equipped with a roof overhang which screens out the sun during the summer but permits transmission through the windows during the winter, so that the windows function as a passive solar heat system.

The southern-oriented roof surface, which has a tilt of $70^{\circ}$, contains $28 \mathrm{~m}^{2}$ of solar collectors.

Next to the low-energy house a reference house has been built, the architecture and planning of which are identical with the low-energy house. The reference house is insulated to comply with Swedish building standards.

\section{ENERGY CONSERVATION MEASURES}

INSULATION

Wa11s: $250 \mathrm{~mm}$ of mineral wool: $\mathrm{k}=0.17 \mathrm{~W} / \mathrm{m}^{2} \mathrm{x}{ }^{\circ} \mathrm{C}$ Roof: $150 \mathrm{~mm}$ of unineral wool: $\mathrm{k}=0.11 \mathrm{~W} / \mathrm{m}^{2} \mathrm{x}{ }^{\circ} \mathrm{C}$ Floor: $150 \mathrm{~mm}$ of mineral wool: $\mathrm{k}=0.29 \mathrm{~W} / \mathrm{m}^{2} \mathrm{x}{ }^{\circ} \mathrm{C}$ Windowe: 4 layers of glass: $k=1.5 \mathrm{~W} / \mathrm{m}^{2} \mathrm{x}{ }^{\circ} \mathrm{C}$

\section{VENTILATION}

The house is very air-tight, and therefore it was necessary to install a mechanical ventilation 
system, which also distributes the heat in the house.

The air infiltration has not yet been measured, but it is expected to be about 0.2 air changes per hour.

The fresh air ventilation is $200 \mathrm{~m}^{3} / \mathrm{h}$ corresponding to 0.4 air changes per hour.

The ventilation system is provided with heat recovery equipment with an expected efficiency of $70 \%$.

\section{HEAT RECOVERY WASTE WATER SYSTEM:}

Heat recovery equipment is installed in the waste water system. This consists of a 200 liter

scorage tauk for waste woter. $\Lambda$ heat exchanger of copper coils is placed inside the waste water tank and connected to the solar energy storage tank. If the temperature in the waste water tank is higher than the temperature in the solar energy storage tank, a circulation pump will start transferring heat from the waste water tank to the solar storage tank.

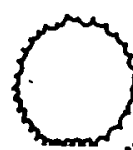

$22 M^{2}$ Low Temperature Collector

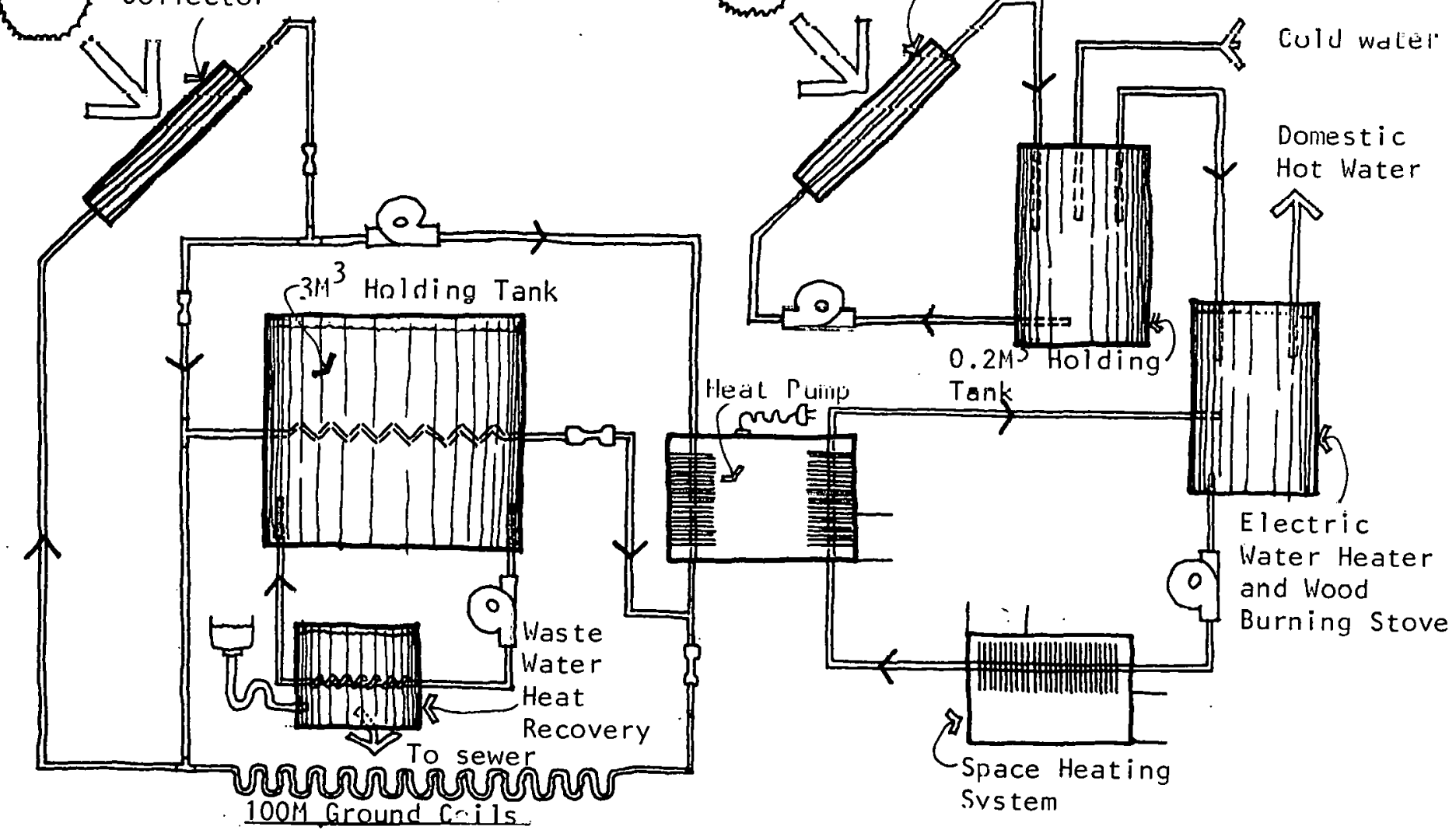

\{

$6 M^{2}$ High temperature Collector

Figure 29 
The energy system consists of 2 solar collector systems and a"heat pump.

The low-temperature solar collector system consists of $22 \mathrm{~m}^{2}$ of collectors with a high heat- loss coefficient and a low efficiency, a water storage tank of $3 \mathrm{~m}^{3}, a$ water-to-water heat pump and $100 \mathrm{~m}$ ground coils. This system primarily covers the space heating load.

The low-efficiency solar collector consists of a black painted heat absorbing panel with one layer of ordinary glass. There is no insulation at the back of the panel, and it may therefore be possible by means of the heat pump to draw heat out of the air circulating behind the solar collector.

The storage tank of $3 \mathrm{~m}^{3}$ is a cylindrical steel tank placed in the basement. The tank is insulated with $20 \mathrm{~cm}$ of mineral wool.

During the year the temperature in the tank is expected to vary between $5^{\circ} \mathrm{C}$ and $45^{\circ} \mathrm{C}$.

The high-temperature solar collector system consists of $6 \mathrm{~m}^{2}$ of collectors with a low heatloss coefficient and a higher efficiency and a water storage tank of 200 liters. This system primarily covers the requirement for doniestic hot water supply.

This solar collector is similar to the lowefficiency solar collector, but insulated at the back of the absorber panel. The temperature in the 200 liter storage tank is expected to vary berweèn $10^{\circ} \mathrm{C}$ and $90^{\circ} \mathrm{C}$.

An electric water heater and a wood burner oven are used as auxiliary heat supply for the domestic hot water storage tank.

OPERATION OF THE ENERGY SYSTEM

The solar energy from the low temperature collector is primarily accumulated in the $3 \mathrm{~m}^{3}$ solar storage tank and secondarily in the ground colls. 
The heat demand is met by the heat pump primarily from the solar storage tank: If the temperature in the larger storage tank falls below $5^{\circ} \mathrm{C}$, the heat pump takes the energy from the ground coils..

Because the ground coils are placed under the house, the heat pump will stop, if the temperature in the coils fails below $5^{\circ} \mathrm{C}$. The heat demand will then be net by auxiliary heat supply.

B. OPERATIONAL \& PERFORMANCE RESULTS

\section{CALCULATED ENERGY BALANCE}

\begin{tabular}{|c|c|c|}
\hline $\begin{array}{l}\text { Heat requirement for } \\
\text { space heating } \\
\text { Heat requirement for } \\
\text { het water supply }\end{array}$ & $\begin{array}{l}6,000 \mathrm{kWh} \\
4,000 \mathrm{kWh}\end{array}$ & . \\
\hline TOTAL HEAT REQUIREMENT & & $10,000 \mathrm{kWh}$ \\
\hline $\begin{array}{l}\text { Heat supply from waste } \\
\text { water recovery: } \\
\text { Heat supply from solar } \\
\text { energy system: }\end{array}$ & $\begin{array}{l}1,000 \mathrm{kWh} \\
7,000 \mathrm{kWh}\end{array}$ & \\
\hline TOTAL HEAT SUPPLY & & $8,000 \mathrm{kWh}$ \\
\hline $\begin{array}{l}\text { Auxiliary heat supply } \\
\text { Electric supply to the }\end{array}$ & heat pump & $\begin{array}{l}2,000 \mathrm{kWh} \\
1,500 \mathrm{kWh}\end{array}$ \\
\hline
\end{tabular}

CON̈CLUSIUNS

Wi.th the energy conservation measures in the construction of the low-energy house, the heat requirement for space heating is calculated to $6,000 \mathrm{kWh}$ per year.

For the reference house, which is insulated acroriting to the Swedish Building Regulations, the heat requirement for space heating is calculated to 20,000 kbh per ycar.

The main part $(6,500$ k.Wh) of the tot.a.t heat requirement for space heating and hot water $(10,000 \mathrm{kWh})$ in the low-energy house is covered by the solar energy system in combination with a heat pump. 


\section{ADDITIONAL INFORMATION}

Additional information may be obtained from the owner and designer of the house Architect Matti Mikkonen, Mobelvagen 5, 51035 Bollebygd, Sweden. 


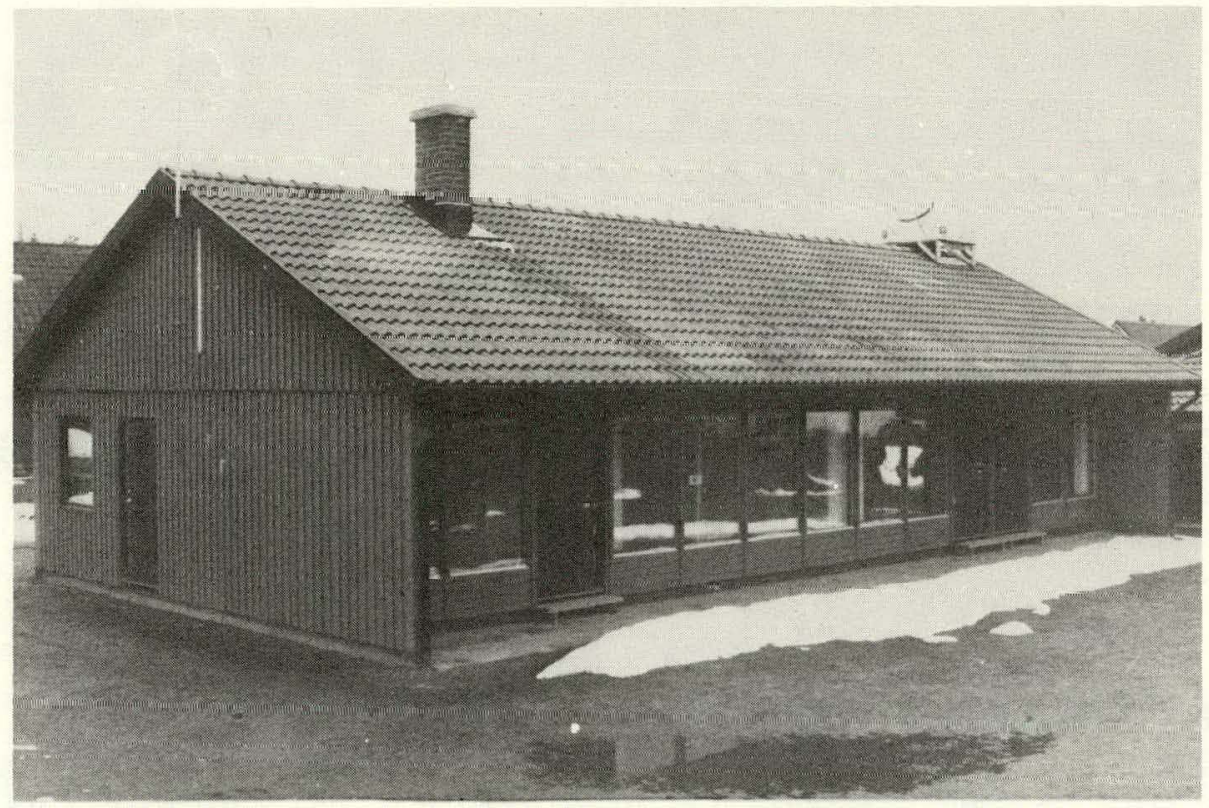

Figure 20

$-60-$ 


\section{PASSIVE SOLAR HOUSE at VETLANDA, SWEDEN}

A. DESCRIPTION

INTRODUCTION

The house was constructed during 1976 by STR - the National Association of Swedish Wooden House Manufacturers. "It was designed by Professor Bo Adamson, the Institute of Technology in Lund and Professor Bengt Hidemark, the Royal Institute of Technology in Stockholm.

The objective of the project was to construct a low-energy building using techniques known today, generally available components and an architectural design consistent with energy conservation.

Solar heating is provided by the windows in the southern facade. Excessively high indoor temperatures are avoided by means of room thermostats; a variable air flow and a fixed solar screening. Heat losses are reduced by means of effective insulation in walls and roof and four-layer glass in windows.

Monitoring of energy utilization was carried out in the building and in a reference building during. the heating season $1976 / 77$ when it was occupied.

\section{CLIMATIC CONDITIONS}

The house is located in Vetlanda, Sweden at a latitude of $57^{\circ}$.

The mean annual number of sunshine hours is 1440.

The annual number of degree days is 4800 calculated with $20^{\circ} \mathrm{C}$ as the design indoor temperature.

DESIGN OF THE BUILDING

The floor area of the building is $120 \mathrm{~m}^{2}$. The. building was a girder framework and a concrete. slab foundation.

There are $18 \mathrm{~m}^{2}$ of four-layer windows facing south which cannot be opened.

The reference house has the same design and the same plan as the low-energy house. The $12 \mathrm{~m}^{2}$ of double-layer windows facing south can all be opened. 
INSULATION VALUES

Walls : $190 \mathrm{~mm}$ of mineral พool:

Roof: $300 \mathrm{~mm}$ of mineral woo1:

$\mathrm{k}=0 / 25 \mathrm{~W} / \mathrm{m}^{2} \times{ }^{\circ} \mathrm{C}$ wool: $\mathrm{k}=0.14 \mathrm{~W} / \mathrm{m}^{2} \mathrm{x}{ }^{\circ} \mathrm{C}$

Floor: $\mathrm{k}=0.19 \mathrm{~W} / \mathrm{m}^{2} \times{ }^{\circ} \mathrm{C}$

Windows with 4 layers

of. glass, $22 \mathrm{~m}^{2}$, south: $\mathrm{k}=1.5$

Windows with 3 layers

of glass, $6 \cdot \mathrm{m}^{2}$ : $\quad \mathrm{k}=2.0$

Windows with 2 layers

of glass, $4 \mathrm{~m}^{2}$ : $\mathrm{k}=3.0$

\section{VENTILATION}

The low-energy house is provided with a supply and exhaust alr system with a varlable flow. Fresh air is drawn in below the outer roof in order to utillize lie ellergy frum the roufing sheet heated by the sun. The air is preheated to $12-14^{\circ} \mathrm{C}$ and is blown into the bullding via air supply devices in the floor. The evacuation of air takes place in the kitchen and the bathroom. Normally the ventilation rate is $100 \mathrm{~m}^{3} / \mathrm{h}$, and it may be $1 \mathrm{n}-$ creased to $440 \mathrm{~m}^{3} / \mathrm{h}$. Due to very careful sealing in the structures, the infiltration rate is as low as 0.1 air changes per hour.

\section{PASSIVE SOLAR SYSTEM}

The passive solar system is integrated into the bullding. 3outh facing windows with an area of $18 \mathrm{~m}^{2}$ and a $160 \mathrm{~mm}$ concrete slab in the floor are the main features of the system. Fxcessive temperatures inside the building are avoided by means of the roof overhang and the ventilation system.

During the winter the temperature has exceeded $26^{\circ} \mathrm{C}$ about 10 times.

The roof is made with an overhang of 1.8 meters.

There is no active solar system installed in the house. 
B. OPERATIONAL AND PERFORMANCE RESULTS

CALCULATED AND MEASURED ENERGY BALANCE

The measurement. system has been operating in the period October 1976 to. April 1977 when the house was unoccupied.

The solar energy collected in the passive system is calculated in two ways:

1) Measured values from vertical pyranometers behind the windows.

2) Difference between building heat loss and auxiliary energy has been calculated.

The second method is probably the more accurate, as parts of the windows are shaded during many days of the year.

On1y $40 \%-50 \%$ of the solar incidence through the windows during a clear day can be utilized. The rest has to be ventilated away to avoid excessive temperatures. However, a considerable amount of the solar energy can be stored in the building structure.

The solar energy contribution to the space heating load has only been $2000 \mathrm{kWh}(12 \%)$ of the total load $17,000 \mathrm{kWh}$. The expected figure was 6,000 kWh $(35 \%)$ of the total load.

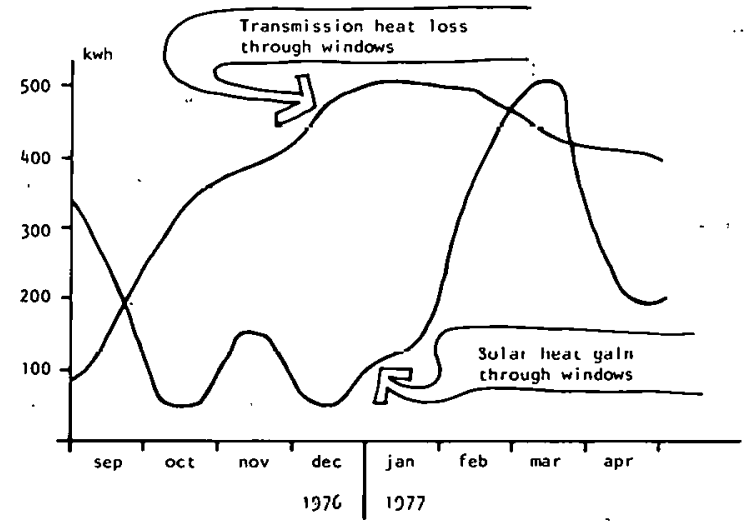

Solar gain and heat loss through $18 \mathrm{~m}^{2}$ of south facing windows. 
This difference is due to:

1) Less insulation than normal

2) The roof was by mistake made with an overhang of $1.8 \mathrm{~m}$ instead of $1.4 \mathrm{~m}$ and thus shaded the window too much.

3) The building was incapable of using all incident solar energy during clear days.

ECONOMIC DATA

During the design period it was determined that the energy conservation features should not cost more than 15,000 Swedish kroner. ( $\$ 3,500$ US).

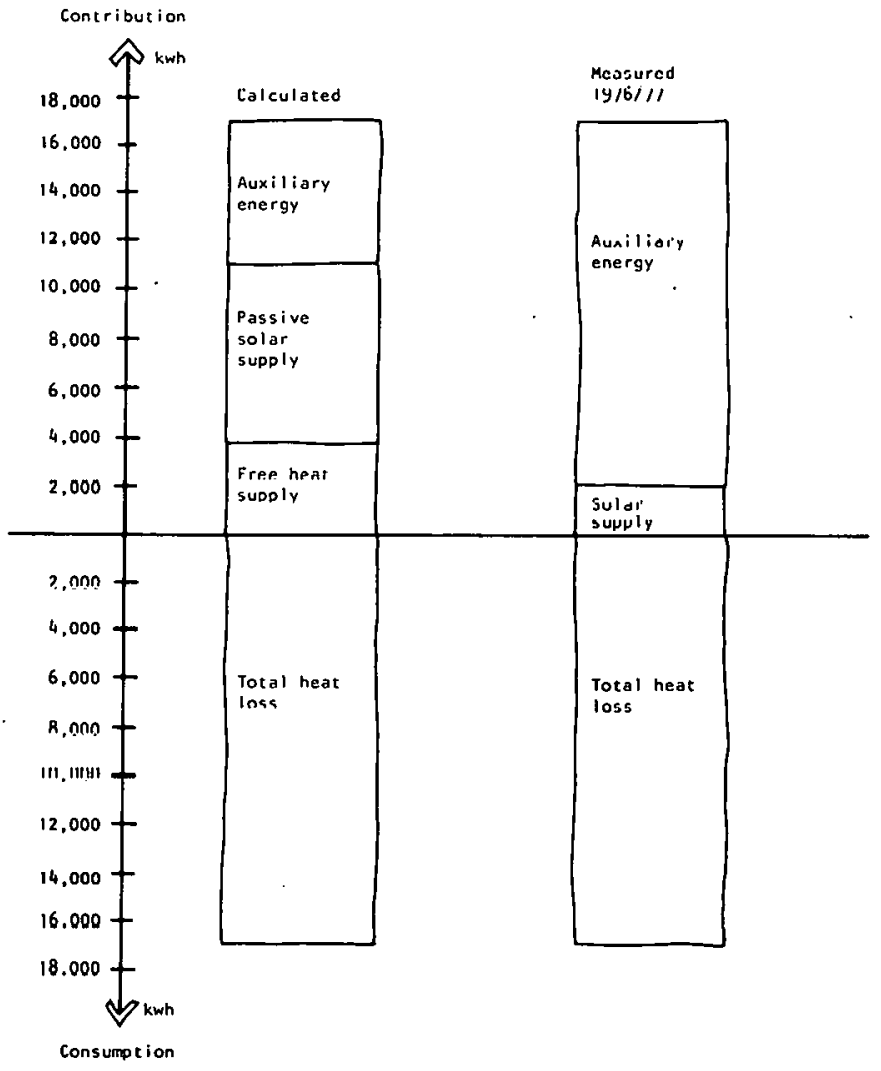

Figure 32 
Information for this section was obtained from the paper: "Passive Solar House in Vetlanda" by Egil Ofverholm, Royal Institute of Technology, Dept. of Architecture, S-10044 Stockholm.

The paper was presented at the CCMS conference "Performance of Solar Heating and Cooling Systems" in Dusseldorf, FRG, April 1978. 


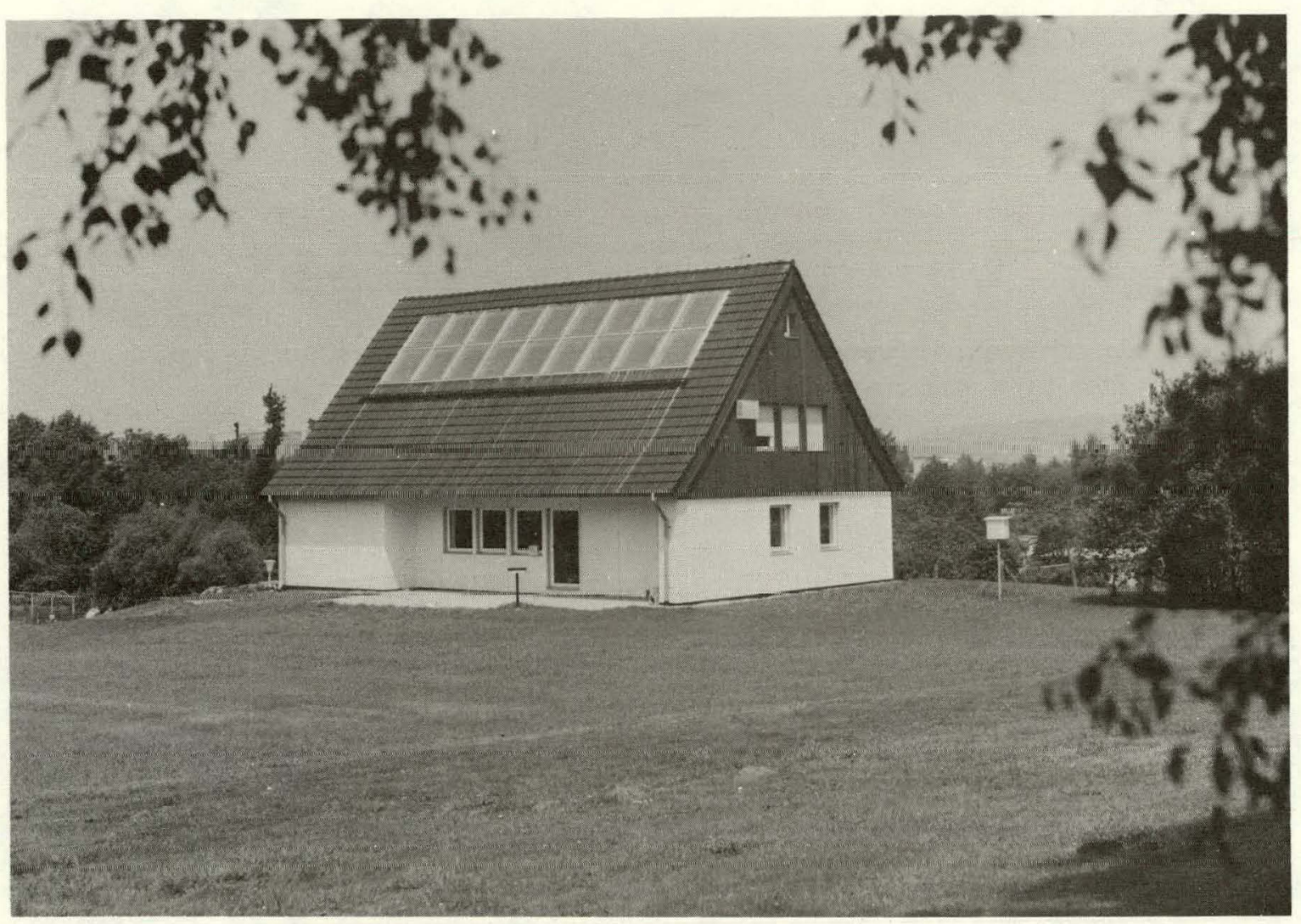

Figure 33

-66 - 
THE PHILIPS EXPERIMENTAL HOUSE at AACHEN, F.R.G.

A. DESCRIPTION

INTRODUCTION

Within the energy research program of the Federal Republic of Germany a study has been made on measures for energy conservation and the utilization of solar energy in buildings. As a part of the experimental program of this study, a low energy house was constructed in 1974.

The following measures have been included in this house: extensive improvement of the insulation of walls and windows, controlled, air ventilation, heat recovery from exhaust air and waste water, the use of heat pumps and the utilization of solar energy with evacuated selected solar collectors.

In the experimental house a mini-computer is used for data acquisition and to simulate a family.

\section{CLIMATIC CONDITIONS}

The house is locted in Aachen, FRG at a latitude of $51^{\circ}$.

The mean annual number of sunshine hours is 1510 .

The mean ambient temperature is $9.4^{\circ} \mathrm{C}$ and the annual number of degree days is 3230 calculated with $19^{\circ} \mathrm{C}$ as the design indoor temperature.

DESIGN OF THE BUILDING

The house was built on the laboratory's testing site and corresponds in shape and size to a standard house for a family of four. The living area is $116 \mathrm{~m}^{2}$. There are $11.4 \mathrm{~m}^{2}$ of windows, of which the majority are oriented toward the south.

The house is organized in the following manner:

The attic contains connections for the solar collector. On the first floor are placed the measuring and simulating equipment. The ground floor is arranged for living - and the normal family's energy consumption is simulated. The cellar contains the energy system with storage tank, heat recovery equipment, heat pumps and air conditioning. 
The envelope components in the house are insulated to the following $k$-values:

Wa11s:

Ceiling:

Floor:

Windows in

Daylight Hours $\quad k=1.9 \mathrm{~W} / \mathrm{m}^{2} \times{ }^{\circ} \mathrm{C}$

Windows at Night $\mathrm{k}=1.3 \mathrm{~W} / \mathrm{m}^{2} \mathrm{x}{ }^{\circ} \mathrm{C}$

Night insulation of the windows consists of roll shutters.

Heat loss through leaks around windows is reduced to approximately $0.1 \mathrm{~m}^{3} / \mathrm{h}$ per meter joint.

This thorough tightening implies that a mechanical. fresh alr system is necessary in order to achieve satisfactory air quality. The fresh air system is equipped with a regenerative heat recovery apparatus of the "thermal wheel" type in which recovery of the enthalpy content in the exhaust air is approximately $90 \%$ effective.

Inlet air.

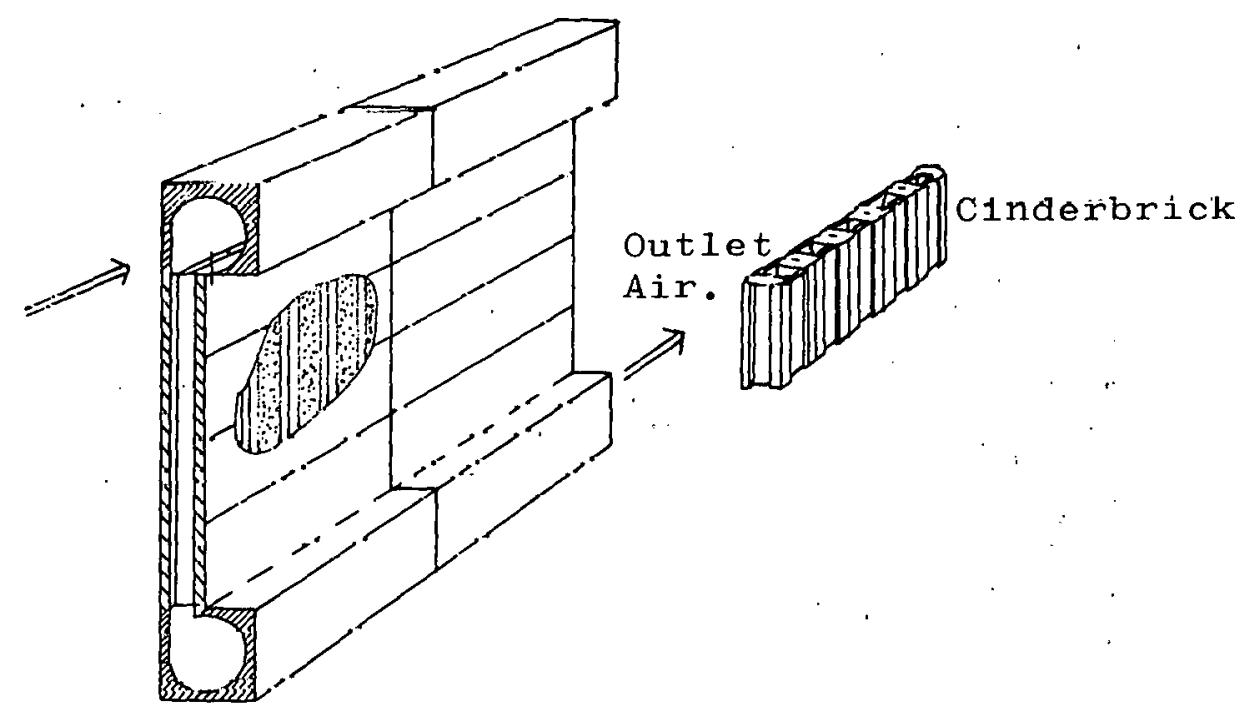

Figure 34 
The fresh air is additionally preheated by circulating through a hollow cinderblock wall covering $65 \mathrm{~m}^{2}$ of the cellar walls, in direct contact with the adjacent earth. This wall, which is used to preheat incoming cold winter air and cool incoming hot summer air, draws the ambient air in at the top of the wall at ground level and distributes this incoming air to vertical channels.

While flowing down these channels, which act as an effective heat exchanger coupling earth to air, the incoming air acquires the temperature of the earth prior to entering the ventilation system of the house. Measurements show, that during a whole winter period with amblent temperatures as low as $-7^{\circ} \mathrm{C}$, the temperature of the air after it has passed through the hollow cinderbrick wall never falls below $5^{\circ} \mathrm{C}$. .

During summer periods with ambient temperatures as high as $30^{\circ} \mathrm{C}$, the cool air which had passed through the cinderblock wall emerged at $17^{\circ} \mathrm{C}$ throughout the day with a ventilation rate of 1 air change per hour.

There is, in addition, heat recovery from waste water from bath and kitchen. A11 waste water flows down to a one cubic meter tank, from where it is cooled by means of a $1.7 \mathrm{~kW}$ heat pump, so that a part of the energy in the waste water can be used for production of hot water.

\section{SOLAR HEATING SYSTEM}

The solar heating system consists of a $20 \mathrm{~m}^{2}$ highly efficient solar collector and two storage tanks of $4 \mathrm{~m}^{3}$ and $42 \mathrm{~m}^{3}$ respectively.

The solar collector, which has a tilt of $48^{\circ}$ is constructed of evacuated glass tubes, in which narrow black painted absorber tubes are mounted. The outer glass tubes are equipped with a mirror at the base which reflects the rays of the sun. The top is coated on the interior surface with a layer of indium oxide $\left(\mathrm{IN}_{2} \mathrm{O}_{3}\right)$, which reflecti the long wave radiant hat from the absorber tube. 


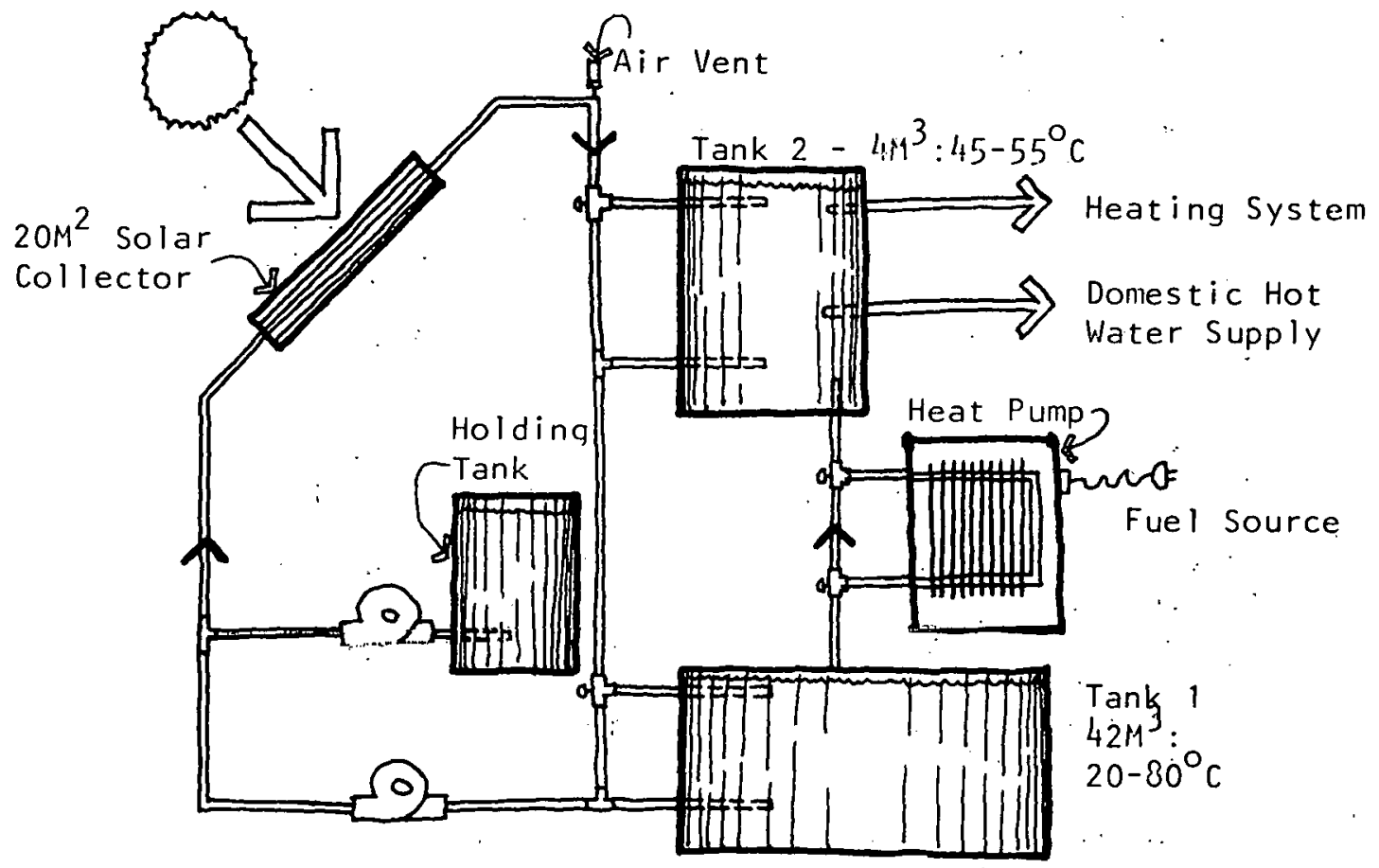

Figure 35

Since there is a vacuum in the glass tube, heat loss from the absorber plate is negligible.

Water is used as the heat transport medium in the solar collector. When there is danger of freezing nr boiling, the systelu is emptied.

Depending on the temperature level, the hot water trom the solar collector 1s delivered cither to the $42 \mathrm{~m}^{3}$ storage tank or to the $4 \mathrm{~m}^{3}$ immediate use tank.

The immediate use.tank, the temperature of which varies between $45^{\circ} \mathrm{C}$ and $55^{\circ} \mathrm{C}$, is used directly for liearing the house and for dnmestic hot water.

The temperature in the large otorage talk varies. between $20^{\circ} \mathrm{C}$ and $80^{\circ} \mathrm{C}$. If the temperature is over $45^{\circ} \mathrm{C}$ the energy is tranefcrrcd direclly from the storage tank to the consumption tank. If the temperature is under $45^{\circ} \mathrm{C}$ the energy is transferred to the immediate use tank via a heat pump.

If the temperature in the storage tank would be under $5^{\circ} \mathrm{C}$, the consumption tank is heated via a heat pump system which has 120 meters of ground colls placed under the cellar floor. 
B. OPERATIONAL AND PERFORMANCE RESULTS

ENERGY BALANCE

The energy consumption for space heating was measured in the winter of $1975 / 76$ and compared with the consumption in a comparable wellinsulated standard house ( $k$-values equal to 0.5 $\mathrm{W} / \mathrm{m}^{2} \mathrm{x}{ }^{\circ} \mathrm{C}$, two-layer glass in windows, no fresh air system with heat recovery):

The energy consumption in the test house was measured to $4000 \mathrm{kWh}$ compared with $24,800 \mathrm{kWh}$ in the standard house.

The solar heating system delivered 3000 of the $4000 \mathrm{kWh}$. The required supplement of $1000 \mathrm{kWh}$ was used to operate the heat pump between the storage tank and the immediate use tank $(900 \mathrm{kWh})$ and the heat pump between the domestic waste water heat recovery system and the immediate use tank (100 $\mathrm{kWh}):$

Heat bolance for spàce liéd irly (1975/76)

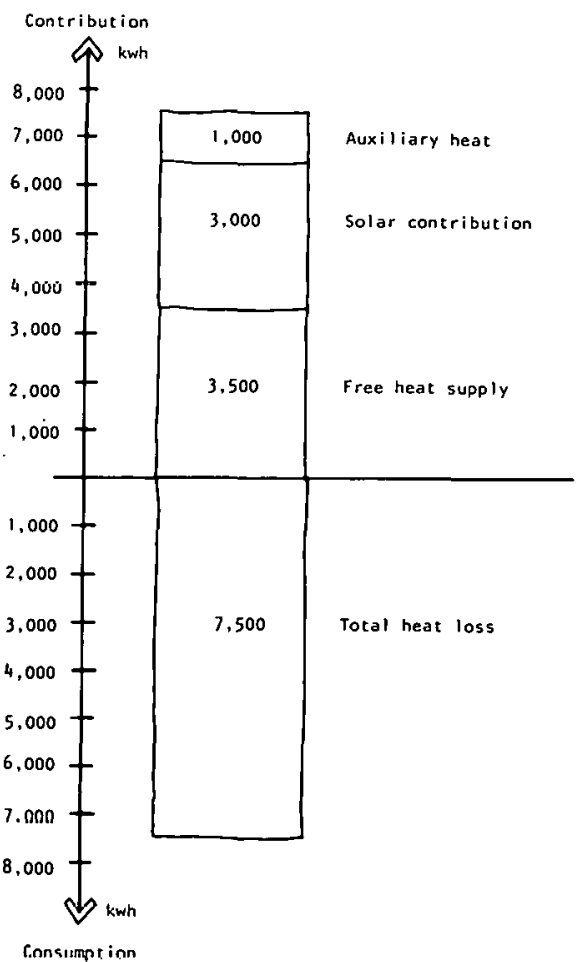

Figure 36 
The ground heating system was not in use during this winter period.

Solar incidence on the solar collector $(20 \mathrm{~m}$ was measured to $24,500 \mathrm{kWh}$ in $1975 / 76$. Of this $9500 \mathrm{kWh}$ (approximately 40\%) was utilized in the solar collector $\left(475 \mathrm{kWh} / \mathrm{m}^{2}\right)$.

The temperature level in the storage tank varied between $15^{\circ} \mathrm{C}$ in January/February, and $60^{\circ} \mathrm{C}$ in August/September.

\section{CONCLUSIONS}

The Philips Research Laboratory draws the following conclusions on the basis of the experimental low-energy house: it can be said, that the reduction of heat loss from buildings and the rational use of energy do reduce the energy needs of buildings considerably. Furthermore, the experimental results show that it is possible to satisfy a large part of the remaining energy demand of such well-planned buildings with solar energy. However, because of the load distribution solar heating unlike solar heated hot water, can only be achieved by using either a collector with a large surface area or seasonal storage, and this is accompanied by low efficiency of the system. 


\section{ACKNOWLEDGEMENT}

Information for this section was obtained from the followig papers:

"The Philips Experimental House - Results and Experiences", First Solar Energy Forum, German Solar Energy Society, Hamburg, September, 1977.

"The Philips Experimental House - A System's Performance Study", CCMS-Performance of Solar Heating and Cooling Systems, Dusseldorf, April, 1978.

Further information from Philips

Forschungslaboratorium Aachen, Weisshausstrasste, D-5100 Aachen West Germany. 


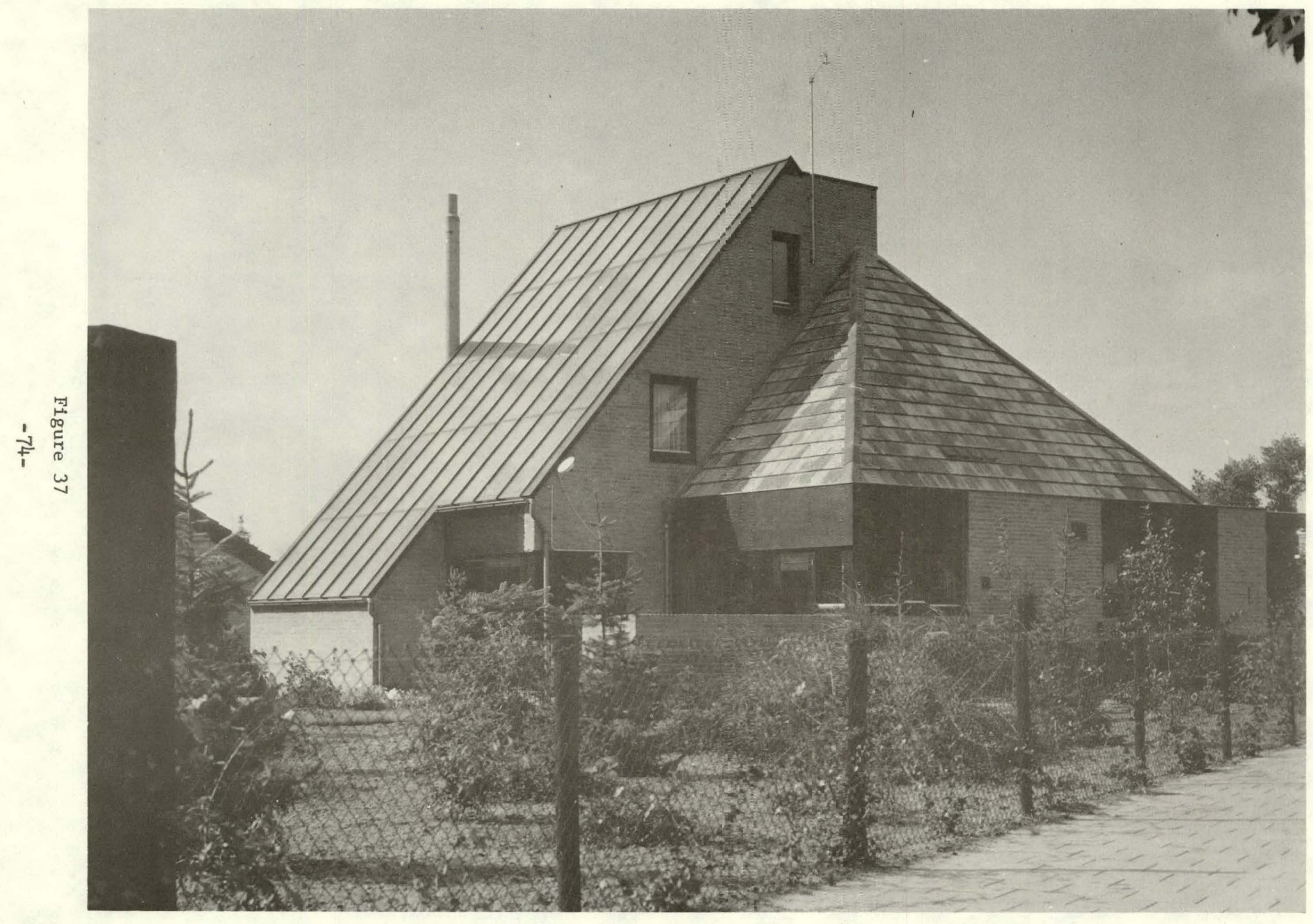




\section{THE EINDHOVEN SOLAR HOUSE, NETHERLANDS}

\section{A. DESCRIPTION}

\section{INTRODUCTION}

After more than three years research and development work, the "Solar House of the Eindhoven University of Technology" was built in 1976/77. In cooperation with the Department of Mechanical Engineering (Professor C.W.J. van Koppen), and the Department of Building Technology (Professor $\mathrm{J}$. Hamaker).

\section{DESIGN OF THE BUILDING}

The house is architecturally and mechanically designed with regard to the solar heating system, which consists of a $51 \mathrm{~m}^{2}$ solar collector integrated in the roof construction and a $4 \mathrm{~m}^{3}$ storage tank placed in the house. It is the first house in Holland with such a large solar collector integrated in the building. The architects have worked intensively with the materials and function of the solar collector in order to. unite the solar collector surface and the house in a satisfactory manner.

The house has a living area of $220 \mathrm{~m}^{2}$ distributed on three floors.

The window area, which is greatly reduced in relation to that in traditional houses, is chlefly oriented toward the south. The window area toward the north, east and west is limited to just meet the demands for daylight.

\section{ENERGY CONSERVATION MEASURES}

In the design of the house emphasis is placed on reducing energy consumption greatly as compared to normal Dutch standards.

The walls are insulated with $75 \mathrm{~mm}$ of mineral wool $\left(\mathrm{k}=0.4 \mathrm{~W} / \mathrm{m}^{2} \mathrm{x}{ }^{\circ} \mathrm{C}\right)$.

The new building code requires insulation of walls corresponding to $\mathrm{k}=0.78 \mathrm{~W} / \mathrm{m}^{2} \mathrm{x}^{\circ} \mathrm{C}, \quad(50 \mathrm{~mm}$ of mineral wool), and the conventional insulation standard in Holland corresponds to $k=1.4 \mathrm{~W} / \mathrm{m}^{2} \mathrm{x}$ ${ }^{\circ} \mathrm{C}$ (cavity wal1).

The roof is insulated corresponding to $k=0.4$ $\mathrm{W} / \mathrm{m}^{2} \mathrm{x}{ }^{\circ} \mathrm{C}$ and the floor to $\mathrm{k}=0.7 \mathrm{~W} / \mathrm{m}^{2} \mathrm{x}^{\circ} \mathrm{C}$. 
All windows are equipped with two layers of glass, and the joints around doors and windows are well weatherstripped.

With these energy-saving measures the design heat loss is calculated to $11 \mathrm{~kW}$ with outdoor temperatures of $-10^{\circ} \mathrm{C}$ and indoor temperature of $20^{\circ} \mathrm{C}\left(366 \mathrm{~W} /{ }^{\circ} \mathrm{C}\right)$.

\section{SOLAR HEATING SYSTEM}

The solar heating system consists of $51 \mathrm{~m}^{2}$ of solar collectors, a water storage tank of $4 \mathrm{~m}^{3}$, a gas-fired auxiliary boiler and an air-heating distribution system.

\section{SOLAR COLLECTOR}

The absorber plates in the collector are designed as radial finned aluminum tubes. The outside of the finned-tube collector plates is provided with a selective absorber coating. This chrome oxide coating absorbs about $92 \%$ of the solar radiation and emits only about $15 \%$ of the heat radiation.

The width of the finned tubes is $150 \mathrm{~mm}$. The whole solar-roof surface consists of forty parallel finned-tubes $9 \mathrm{~m}$ long. The collector plates are protected against weather and dust by a single glass cover.

The solar roof does not consist of separate collector boxes with a water oupply and outlet each, bur forms an integral part of the roof structure.

\section{SPECIAL FROST PROTECTION EQUIPMENT}

During periods of frost the water in the finnedtuhes will freeze, and precautions must be taken to prevent the tubes from being damaged by the expansion caused by the freezing.

The moot common method of frusl procection is adding glyool to the watcr in the collector. In this method it is necessry to install a heat exchanger, which involves extra costs and decreases the heat gain of the solar heating system. 


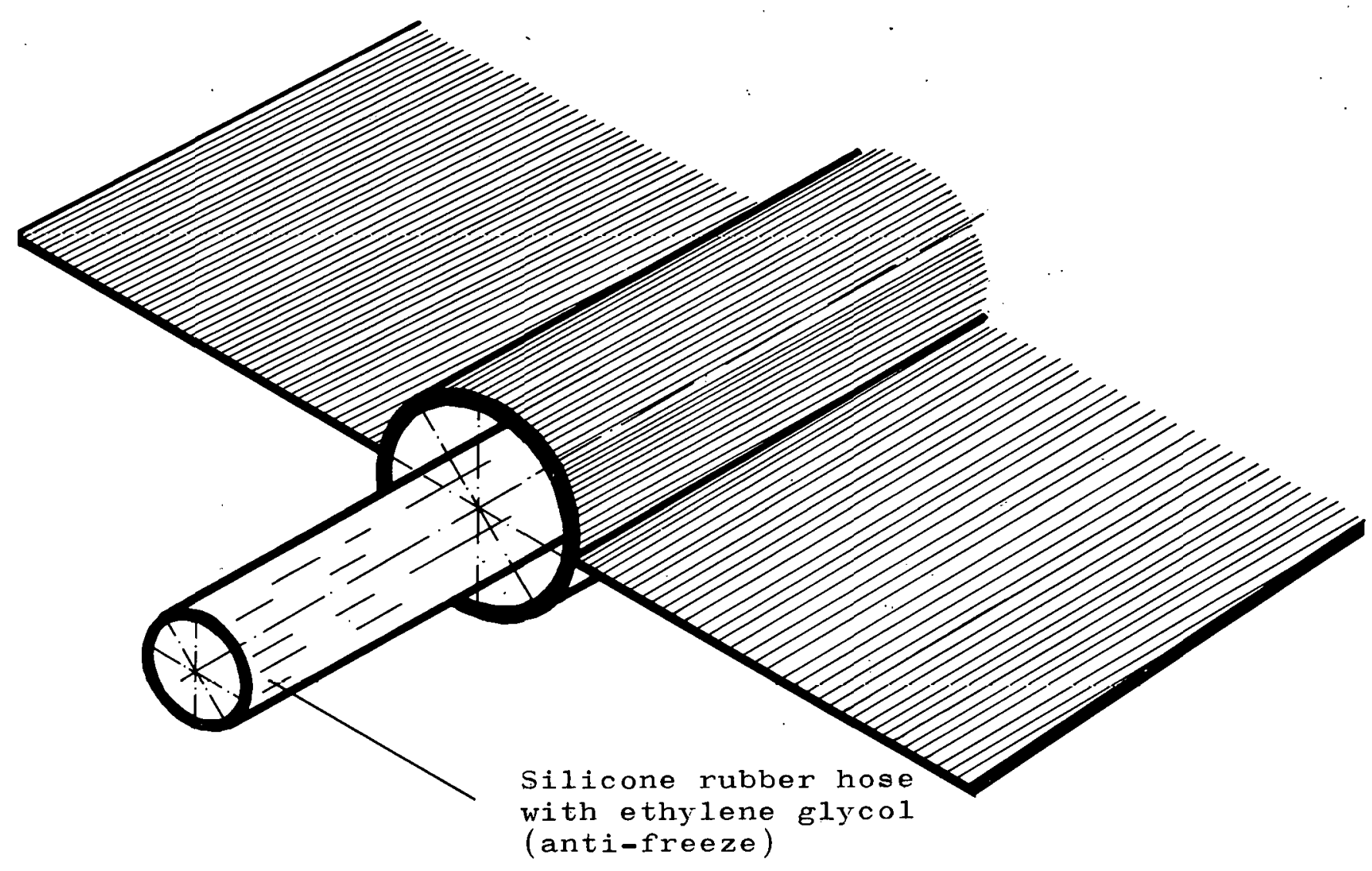

Figure 38

Therefore, a new method of frost protection is applied. A silicon rubber hose, filled with glycol, is placed inside the finned-tubes. The hoses are all connected with a small expansion vessel outside the water system. The hose inside the tube is squeezed flat, when the waler freezes and the glycol flows to the expansion vessel.

The experience with this system has been positive and no damage to or leakage from the finned-tubes has occurred.

The frost protection system described is not. a universal solution to the freezing problem. It is only applicable $1 \mathrm{n}$ the finned-tube absorption plates and it necessitates more elaborate installation work. 
The solar energy is stored in a water tank of 4 $\mathrm{m}^{3}$. In order to utilize the heat as well as possible, special attention has been given to the thermal stratification of the water in the storage tank.

Thermal stratification means the highest temperature at the top and lowest at the bottom of the tank. The temperature increases gradually from the bottom to the top. The water from the collector has a variable temperature because of the fluctuating intensity of the solar radiation. The water coming from the collectors is always supplied to the level in the tank where the temperature is equal to that of the water from the collectors. This is achieved by use of a floating Inler, a flexible thin walled plastic hose.

The floating inlet makes $5 \%$ more energy available to the whole solar heating system.

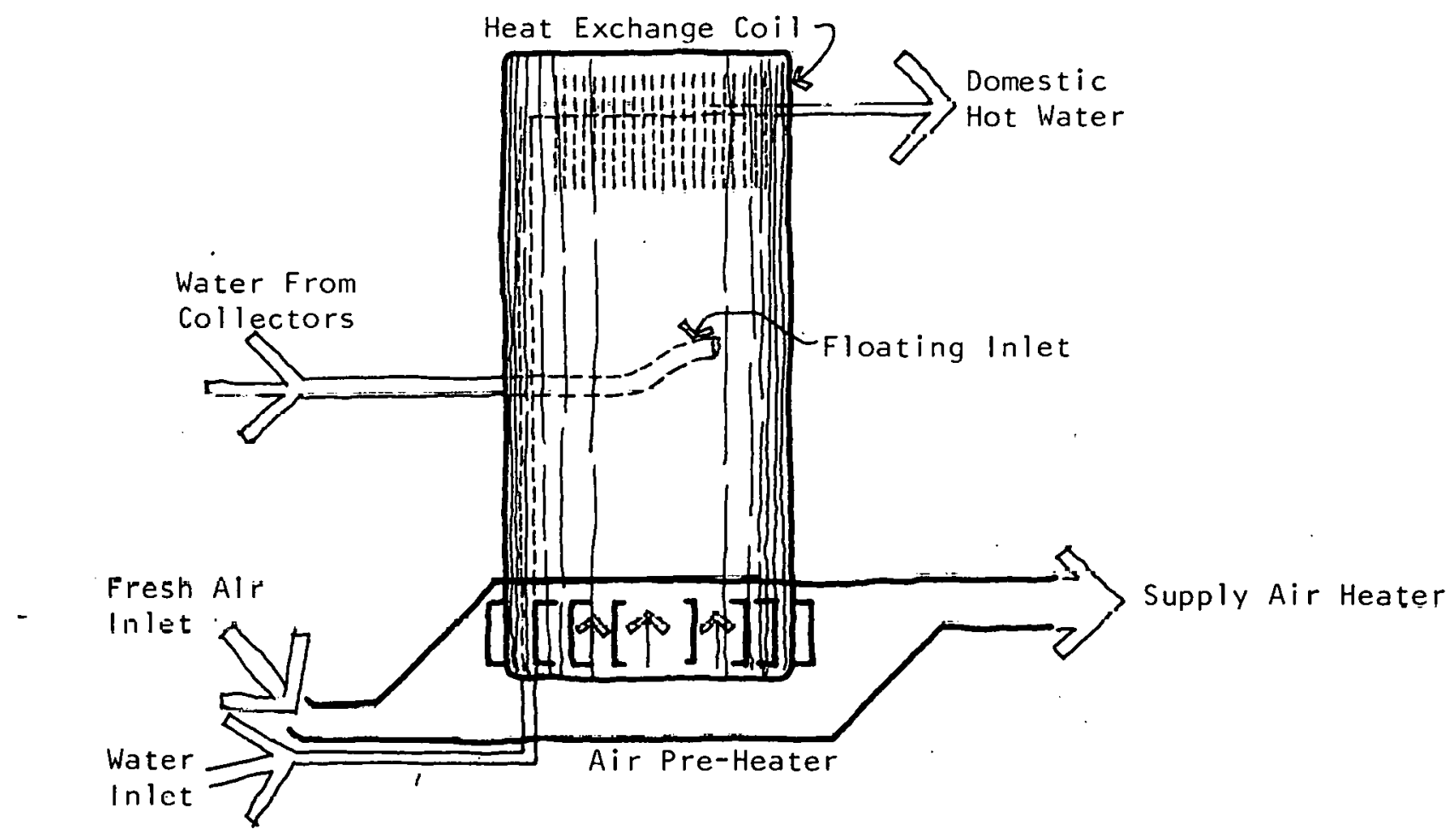

Figure 39 
The hot water supply for the house is provided with a heat exchange coil at the top of the tank. The water flows through the coil from the bottom to the top and reaches a temperature close to the temperature at the top of the tank.

A casing is mounted around the lower part of the storage tank. Fresh air for the house is preheated flowing through it, and the water in the bottom is cooled. The temperature of the water flowing to the collectors is kept as low as possible in this way, which increases the efficiency of the collectors. To improve the heat flow from the tank to the air, thin fins are fixed on the bottom part of the tank.

The stored heat is adequate for heating the house for two days in average winter weather.

B. OPERATIONAL \& PERFORMANCE RESULTS

CALCULATED ENERGY BALANCE

Heat load for space heating

and domestic water

$22,000 \mathrm{kWh}$ per year

Heat supply from the solar

energy system

$10,000 \mathrm{kWh} \quad(45 \%)$

Auxiliary energy

(natural gas)

$12,000 \mathrm{kWh}$ per year

\section{ACKNOWLEDGEMENT}

Information for this section has been obtained from Professor C.W.J. van Koppen and from the report: "The Solar House of the Eindhoven University of Technology" by J. Hamaker, H.C.A. Hoekstra, C.W.J. van Koppen and J.T.T. van Wolde. 


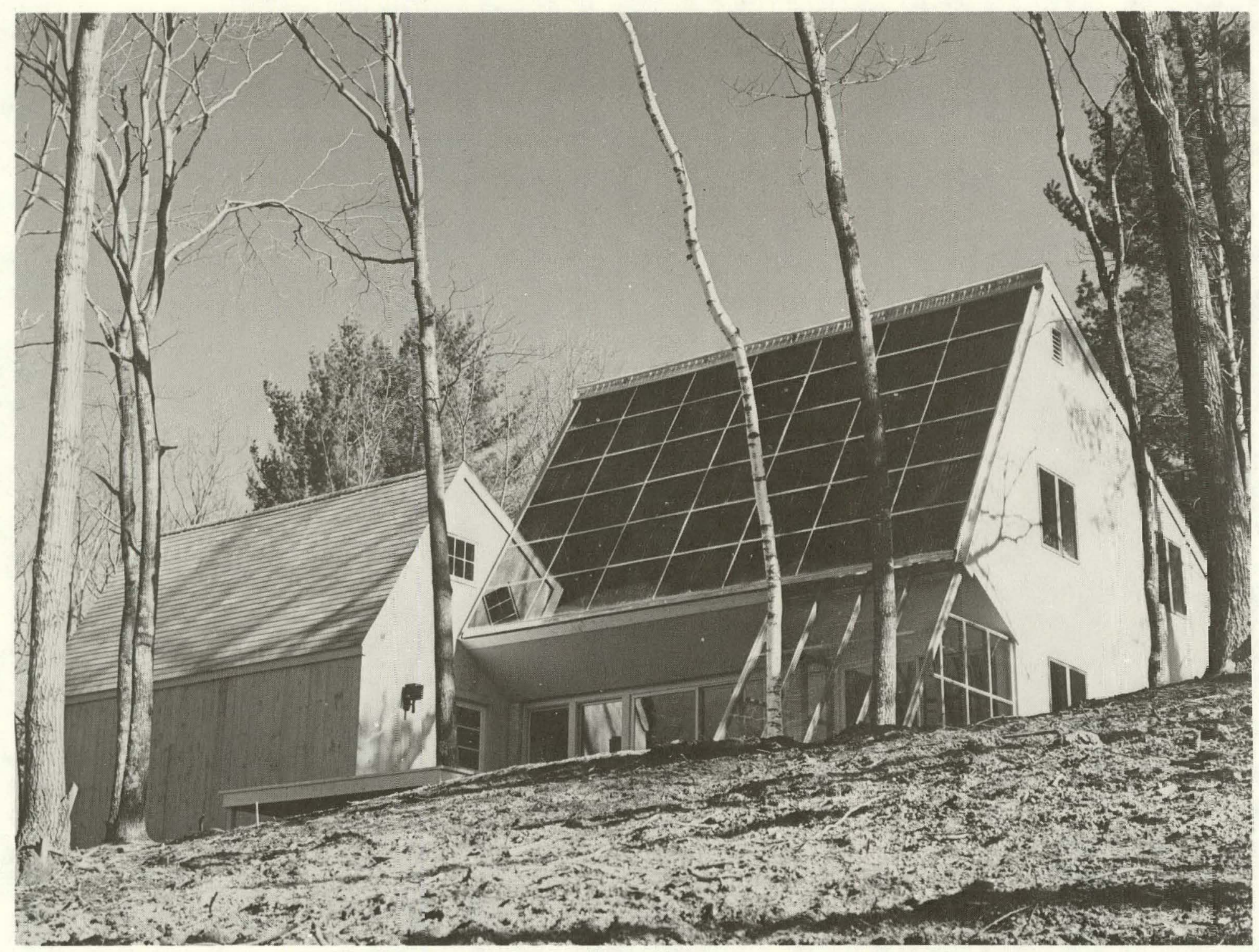




\section{THE GOOSEBROOK SOLAR HOME at NEW HAMPSHIRE, U.S.A.}

\section{A. DESCRIPTION \\ INTRODUCTION}

The Goosebrook Solar Home in Harrisville, New Hampshire, U.S.A., was built in $1976-77$ by Total Environmental Action Inc., with Dr. Bruce Anderson as project leader.

The intent was to build a house in which energysaving measures are combined with an active and a passive solar heating system, without great variation in the architecture or price, when the house was compared to other houses in the area.

DESIGN OF THE BUILDING

The house has living area of $135 \mathrm{~m}^{2}$ with an open-plan ground floor including living room and kitchen, and an upper floor with three bedrooms. A little greenhouse is located in front of the living room's south facade, and a double garage with sharply pitched roof is placed west of the house.

The active part of the solar heating system for the house is comprised of a $50 \mathrm{~m}^{2}$ solar collector in the southern-oriented roof surface, while the passive part consists of $25 \mathrm{~m}^{2}$ of the windows in the southern facade.

\section{ENERGY CONSERVATION MEASURES}

The components in the house are insulated according to the following $k$-values:

Exterior walls (150 mm of minera1 woo1):

$$
\mathrm{k}=0.23 \mathrm{~W} / \mathrm{m}^{2} \times{ }^{\circ} \mathrm{C}
$$

Ceiling ( $375 \mathrm{~mm}$ of

cellulose loose fill): $\quad k=0.14 \mathrm{~W} / \mathrm{m}^{2} \mathrm{x}{ }^{\circ} \mathrm{C}$

Windows (3-1ayer glass): $\quad k=2.3 \quad W / \mathrm{m}^{2} \mathrm{x}{ }^{\circ} \mathrm{C}$

The windows toward north, east and west have three-layer glass, while the southern windows which comprise $70 \%$ of the total window area, have two-layer glass and insulating shutlers. The shutters, which are mounted manually, are stored in the garage during the day. 
All joints around doors and windows are carefully tightened against air infiltration. The mechanical ventilation system provides for a fresh air change rate of 0.75 times per hour.

SOLAR HEATING SYSTEMS

The active part of the solar system uses water as a transportation and storage medium. The solar collectors are constructed according to Harry Thomason's principle with black-painted corrugated aluminum panels as absorbers. Water runs directly over the panels and is heated. The absorber panels are covered by one layer of glass.

The storage system, which was developed by Total Environmenl 1 Action, consists of 18 series-plumbed fiberglass tanks (diameter $450 \mathrm{~mm}$ height $2000 \mathrm{~mm}$ ), with a comhined volume of $6 \mathrm{~m}^{3}$ The water-filled tanks, which are placed in an insulated chamber, function both as storage and heat exchanger.

When the house is heated, air is circulated through the storage chamber, where it picks up heat from the waterfilled fiberglass tanks. The storage system can supply heat to the house as long as the water temperature in the tanks is higher than the room temperature. This allows the solar collectors to operate at relatively low temperatures $\left(20-50^{\circ} \mathrm{C}\right)$, which is the maximum range for Thomason's sular collectors.

\section{PASSIVE SYSTEM}

'l'he passive portion of Goosebrooks solar heating system uses the window area in the entire southfacing facade. A row of water-filled fiberglass tanks is placed behind the window wall. When the sun shines through the window, the water in the tanks is heated. At night or in clondy periodo tlie tanks radiate heat to the house. To lessen heat loss frnm the tanks al nfght, exterior movable insulating doors are pulled to cover the glass.

\section{BACK-UP SYSTEM}

The Goosebrook house uses electricity as supplementary heat. Since low-energy houses in the same area often will have a simultaneuus need for supplementary heat, a great load demand is placed on the power plant. 


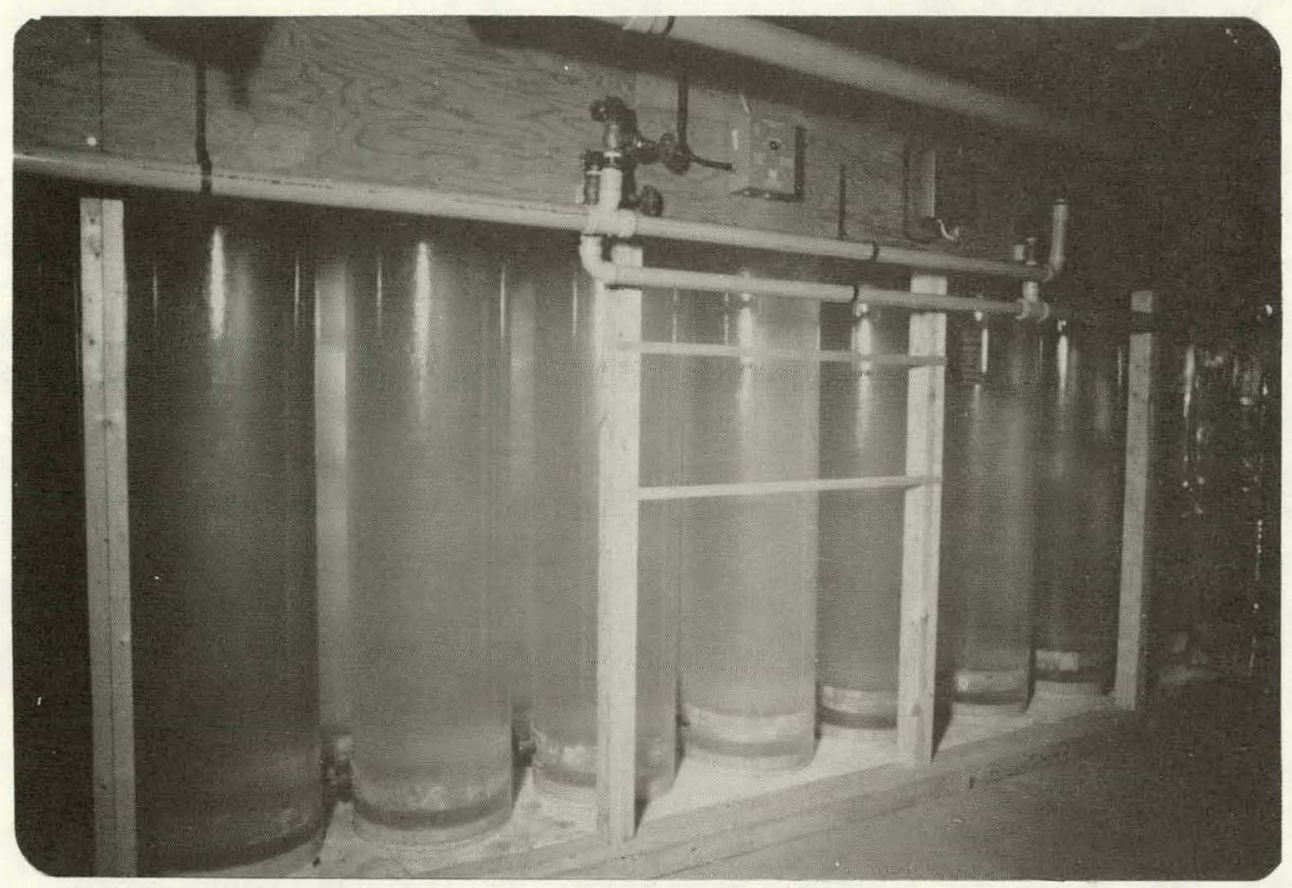

Figure 41

In an attempt to reduce the peak demand on the power plant, an 850-1iter heat-store is installed in the Goosebrook house, for heating with electricity during nighttime hours, when electricity is cheapest and the power load is lowest.

B. OPERATIONAL \& PERFORMANCE RESULTS

\section{ENERGY BALANCE}

The design heat loss of the house calculated to $200 \mathrm{~W} /{ }^{\circ} \mathrm{C}$ corresponding to $8.5 \mathrm{~kW}$ in the New Hampshire area, where the design outdoor temperature is $-23^{\circ} \mathrm{C}$.

The house's energy consumption for heating is calculated to approximately $15,000 \mathrm{kWh} /$ year. Approximately $1 / 3$ of the demand is met by the active solar heating system, approximately $1 / 3$ by passive solar heat, and approximately $1 / 3$ by supplementary heat.

In the heating season 1977/78, $4600 \mathrm{kWh}$ of supplementary heat were used. 
The sales price of the Goosebrook house is $\$ 70,000$ US. The cost of a comparable house without energy saving provisions is $\$ 55,000$. The extra cost, of $\$ 15,000$ is financed with a 25 year mortgage at $8-1 / 2 \%$ interest.

With the current energy price of $\$ 0.02$ per $\mathrm{kWh}$ and an expected increase in the cost of energy of $10 \%$ per year, the energy savings in the course of the 25 years will be greater than the expense of financing the mortgage, so that rent will be cheaper in the low-energy house than in the traditional home.

\section{CONCLUSIONS}

Due to the energy-saving measures in the Goosebrook house, the heating requirement for the house, without solar heat, is only about half of the heating requirement for a traditional house. The solar heating system is very simple in its construction and maintenance.

The combination of energy-saving measures with the active and passive solar heating systems means a reduction in the heating requirement to approximately $1 / 5$ compared with a comparable house built according to traditional methods.

In the first heating season the houoc was supplied with $4600 \mathrm{kWh}$ as supplementary heat in the form of stored electricity,

The energy-saving measures including the solar heating systems increase the sales price by about $25 \%$, or $\$ 15,000$ US. Even so, the energy savings achieved will be greater than the expense of financing the additinnal expendilure seen over the course of the term of tlee mortgage. 


\section{ACKNOWLEDGEMENT}

Information for this section was obtained directly

from Dr. Bruce Andersen, and from the article:

"Goosebrook" by Helene Kassler, Solar Age,

December 1977.

Further information can be obtained from Total

Environmental Action Inc., Church Hill,

Harrisville, New Hampshire 03450, U.S.A. 


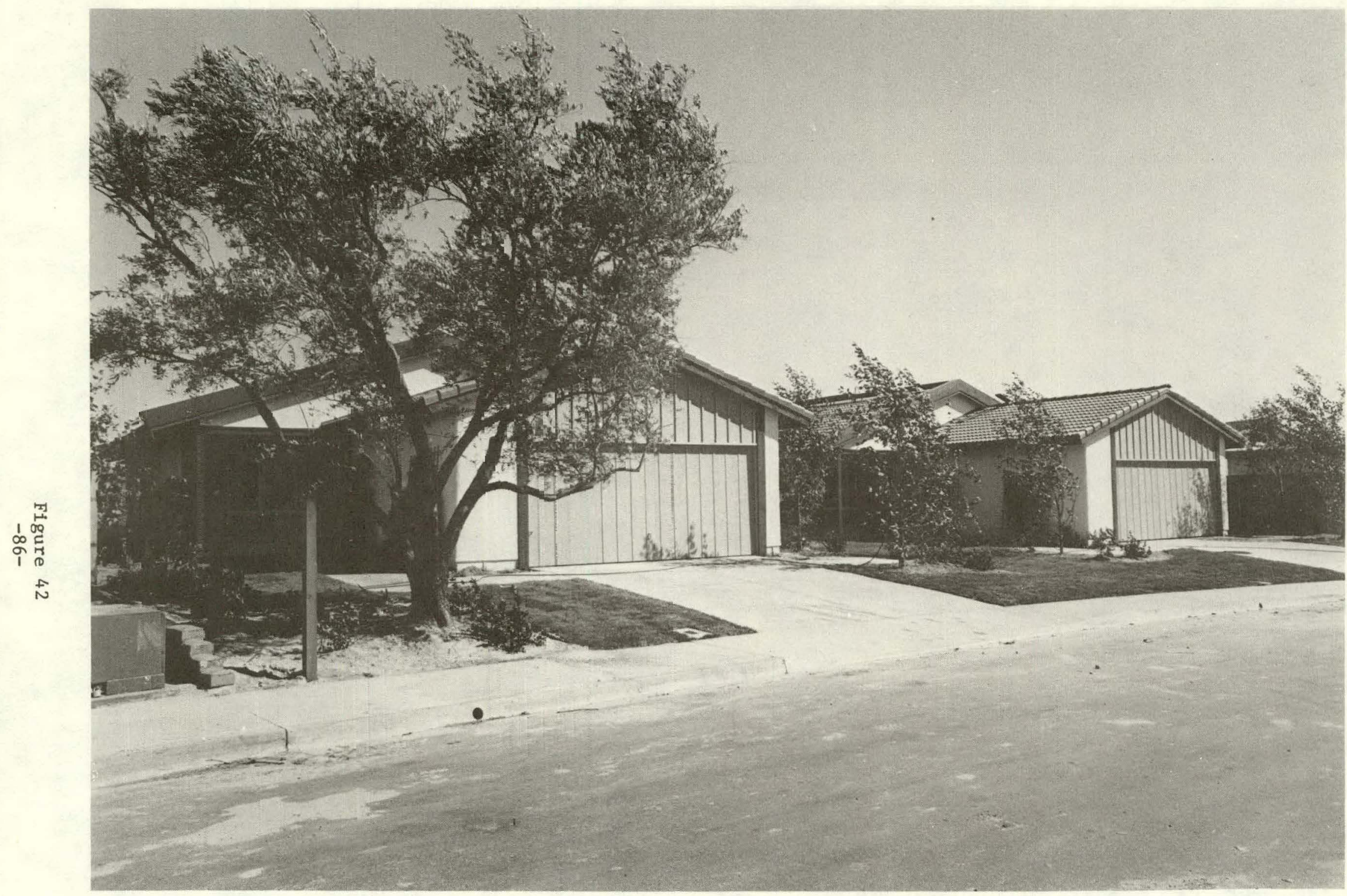




\section{THE MINIMUM ENERGY DWELLING IN MISSION VIEJO, CALIFORNIA U.S.A.}

\section{A. DESCRIPTION}

\section{INTRODUCTION}

The Minimum Energy Dwelling (MED) is an energy conservation and demonstration effort sponsored jointly by the federal government and private industry.

The major goal is to reduce energy consumption in a typical southern California home by at least 50 percent and to encourage the American building industry to adopt the MED energy-saving features.

Principal MED Sponsors are the Federal Department of Energy, Southern California Gas Company and the Mission Viejo Company, California.

An important part of the overall research is the publication of a workbook for architects, engineers and builders to provide detailed information about minimum energy dwellings.

\section{DESIGN OF THE BUILDING}

The demonstration dwelling designed and built in 1976 in Mission Viejo has a size of approximately $110 \mathrm{~m}^{2}$. Through the use of energy conserving appliances, insulation, window and wall shading, exterior coloring and thermal mass, the yearly energy usage has been reduced to $50 \%$.

of the remaining $50 \%$ of the energy required, the majority is supplied by a solar energy system with $30 \mathrm{~m}^{2}$ evacuated tube collectors. The hot water provided by the collectors is used to run an absorption chiller for cooling, the domestic hot water and the heating system.

The remaining energy requirements are met by an auxiliary natural gas energy system.

The performance of the Minimum Energy Dwelling is being compared to another home in Mission Viejo with exactly the same style and size as the MED home, but without the energy-saving features. 


\section{ENERGY CONSERVATION MEASURES}

The components in the house are insulated according to the following k-values:

$\begin{array}{ll}\begin{array}{l}\text { Exterior walls (150 mm of } \\ \text { mineral wool) }\end{array} & k=0.29 \mathrm{~W} / \mathrm{m}^{2} \times{ }^{\circ} \mathrm{C} \\ \text { Ceiling (230 mm of mineral } & \\ \begin{array}{ll}\text { wool) } & \mathrm{k}=0.19 \mathrm{~W} / \mathrm{m}^{2} \times{ }^{\circ} \mathrm{C} \\ \text { Windows (2-1ayer glass): } & \mathrm{k}=4.1 \mathrm{~W} / \mathrm{m}^{2} \times{ }^{\circ} \mathrm{C} \\ \text { Door } & \mathrm{k}=0.60 \mathrm{~W} / \mathrm{m}^{2} \mathrm{x}{ }^{\circ} \mathrm{C}\end{array}\end{array}$

There are $14 \mathrm{~m}^{2}$ of double pane windows with adjustable shutters between the panes, which allow the sun to be blocked out during the summer period.

Vertical shading wings protrude from exterior walls on each side of the windows to reduce the amount of sun hitting the windows. The roof extension is lengthened for better shading over windows and walls.

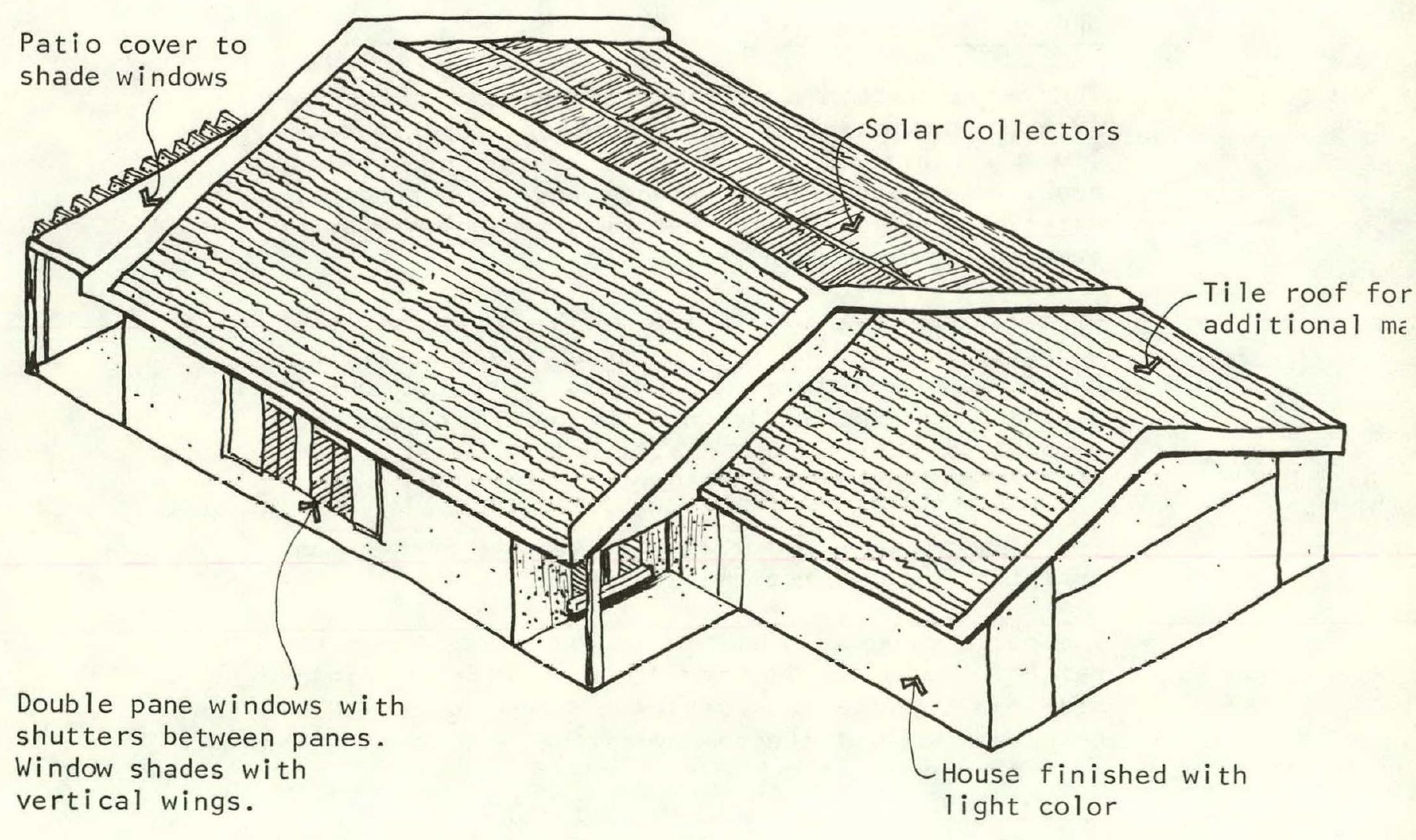


Plastic rather than standard building paper is wrapped around the wood structure as a barrier against outside air infiltration.

The front door is foam-filled steel with magnetic weatherstripping reducing the air infiltration and increasing the standard door insulation. In addition, double-entry doors are used, one leading to an entry area and a second leading into the living room.

Red tile is used on the roof to lengthen the time it normally takes to heat up the living area on warm days.

Household appliances have energy conserving features.

Heat ejected from the refrigerator compressor and condensor coil is channeled outside during the summer and into the home during the winter.

\section{SOLAR HEATING SYSTEM}

The Minimum Energy Dwelling is heated and cooled with solar energy and the domestic hot water is preheated with solar energy. The system uses natural gas as the backup fuel, when the solar energy is insufficient.

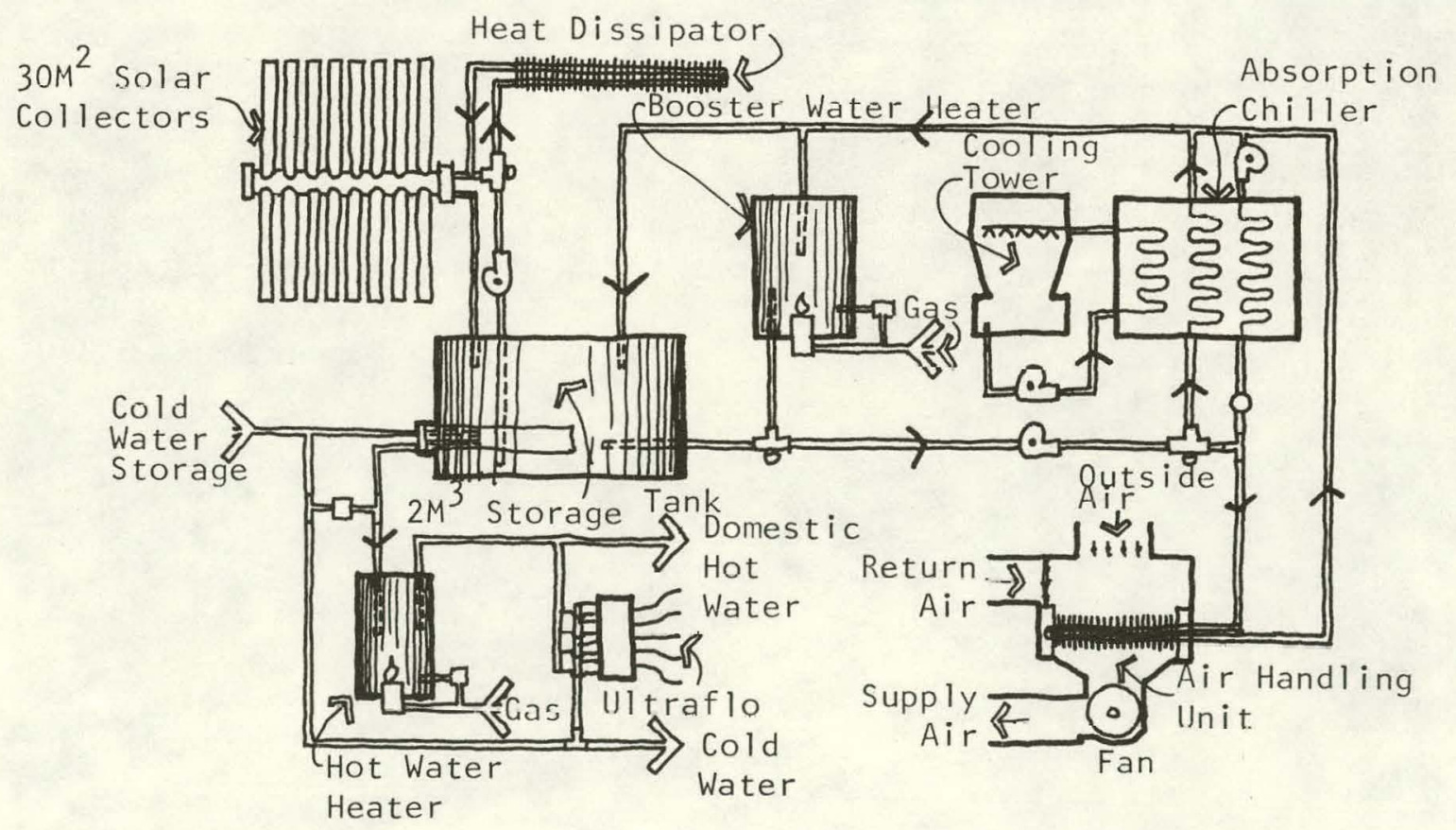




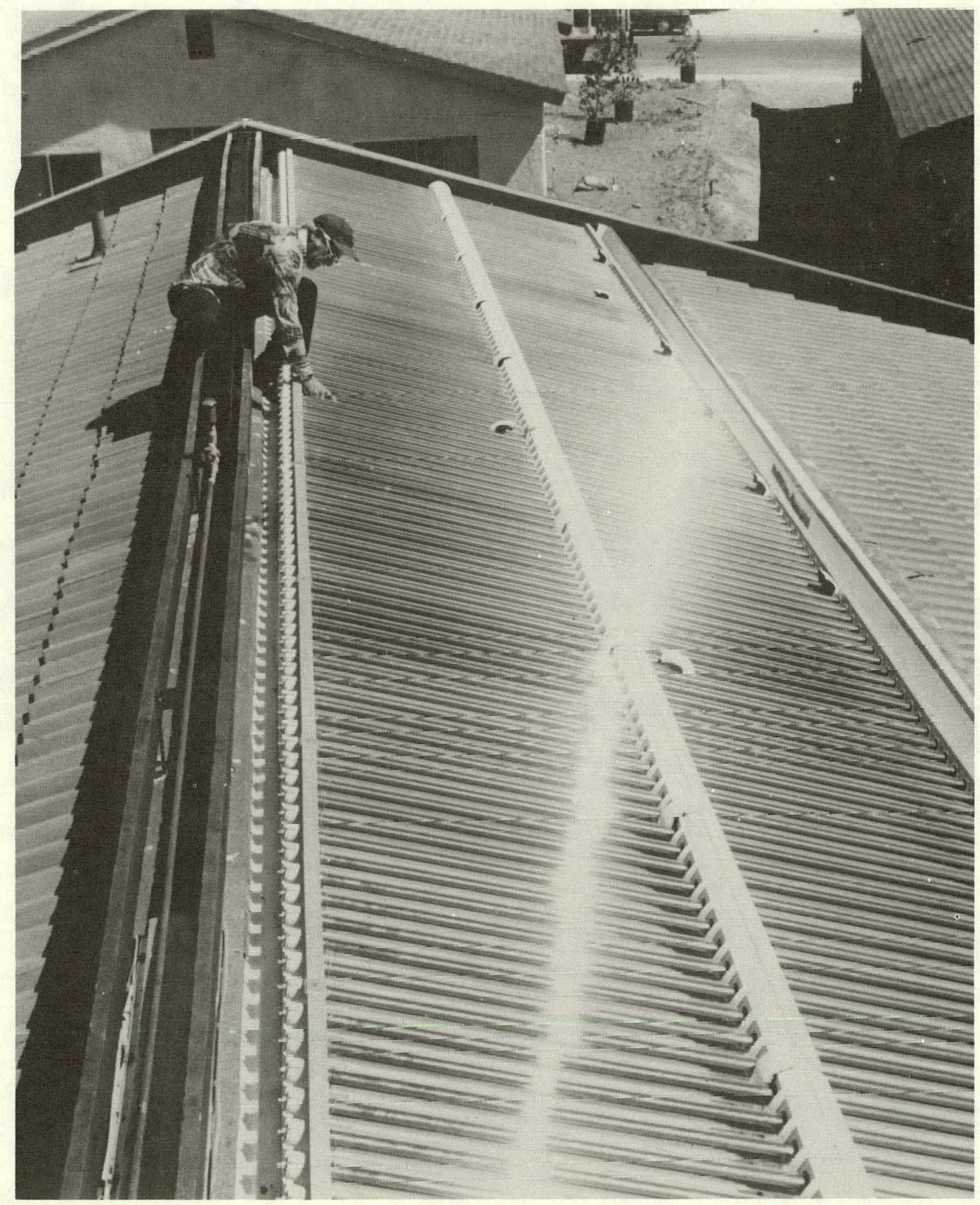


A total of $30 \mathrm{~m}^{2}$ of evacuated tube solar collectors mounted on the roof gather the solar energy.

With a storage capacity of about $3 \mathrm{~m}^{3}$ the solar system can provide all the energy needed at night after a clear, sunny day. The storage tanks are located below ground. level in insulated concrete vaults in the garage.

Heating and cooling are accomplished through a device known as a "single coil air handler". It has either chilled or hot water running through it. The hot water is supplied directly from storage. Chilled water comes from a hot water fired absorption chiller. The unit produces three tons of cooling with $90^{\circ} \mathrm{C}$ water from the solar system.

B. OPERATIONAL AND PERFORMANCE RESULTS

\section{CALCULATED ENERGY BALANCES}

Space Heating Requirements:

\begin{tabular}{|c|c|c|}
\hline $\begin{array}{l}\text { Transmission loss through } \\
\text { walls, floor and ceiling } \\
\text { Transmission loss through } \\
\text { windows } \\
\text { Infiltration loss }\end{array}$ & $\begin{array}{l}245 \mathrm{kWh} \\
245 \mathrm{kWh} \\
155 \mathrm{kWh} \\
\end{array}$ & \\
\hline & & $645 \mathrm{kWh}$ \\
\hline $\begin{array}{l}\text { Heat supply from occupants } \\
\text { Heat supply from electric } \\
\text { appliances } \\
\text { Heat supply from window } \\
\text { solar gain }\end{array}$ & $\begin{array}{l}60 \mathrm{kWh} \\
165 \mathrm{kWh} \\
120 \mathrm{kWh} \\
\end{array}$ & \\
\hline & & $345 \mathrm{kWh}$ \\
\hline
\end{tabular}




\begin{tabular}{|l|r|r|}
\hline $\begin{array}{l}\text { Heat gain through walls, } \\
\text { floor and ceiling }\end{array}$ & $425 \mathrm{kWh}$ \\
Window solar gain & $5 \mathrm{kWh}$ & \\
Heat gain from occupants & $80 \mathrm{kWh}$ & \\
\hline \multicolumn{2}{|c|}{} & $510 \mathrm{kWh}$ \\
\hline \hline $\begin{array}{l}\text { Transmission loss through } \\
\text { windows }\end{array}$ & $120 \mathrm{kWh}$ & \\
$\begin{array}{l}\text { Infiltration loss } \\
\begin{array}{l}\text { Heat loss from electric } \\
\text { appliances due to the } \\
\text { refrigerator heat } \\
\text { ejertinn system }\end{array}\end{array}$ & $85 \mathrm{kWh}$ \\
\hline
\end{tabular}

Out of the 8760 hours in a year, heating or cooling is required less than $12 \%$ of the time. The load is so low due to the relatively mild climate and proper design of the house.

The total energy requirement of about $5000 \mathrm{kWh}$ per year ( $300 \mathrm{kWh}$ for space heating, $280 \mathrm{kWh}$ for space cooling and about $4400 \mathrm{kWh}$ for domestic hot water) is met by the solar heating system with natural gas as the backup fuel.

\section{CONCLUSIONS}

'The Minimum Energy Dwelling research project is designed to demonstrate that the living standards and comfort can be maintained or even improved, while the average family reduce their total energy conoumption by at lcact 50 percent.

Many feacures used in the MED home, exclustve of the solar system, can be adopted almost lunediately by bullders. These features are commercially available right now and need only to be adopted by the building community. 
Information for this section was obtained from Richard Rittelmann at Burt Hill Kosar Rittelmann Associates, Architects, 400 Morgan Center, Butler, PA 16001, USA.

Additional information can be obtained from the "Minimum Energy Workbook" from Southern California Gas Company, P.0. Box 3249, Los Angeles, California 90051, USA. 


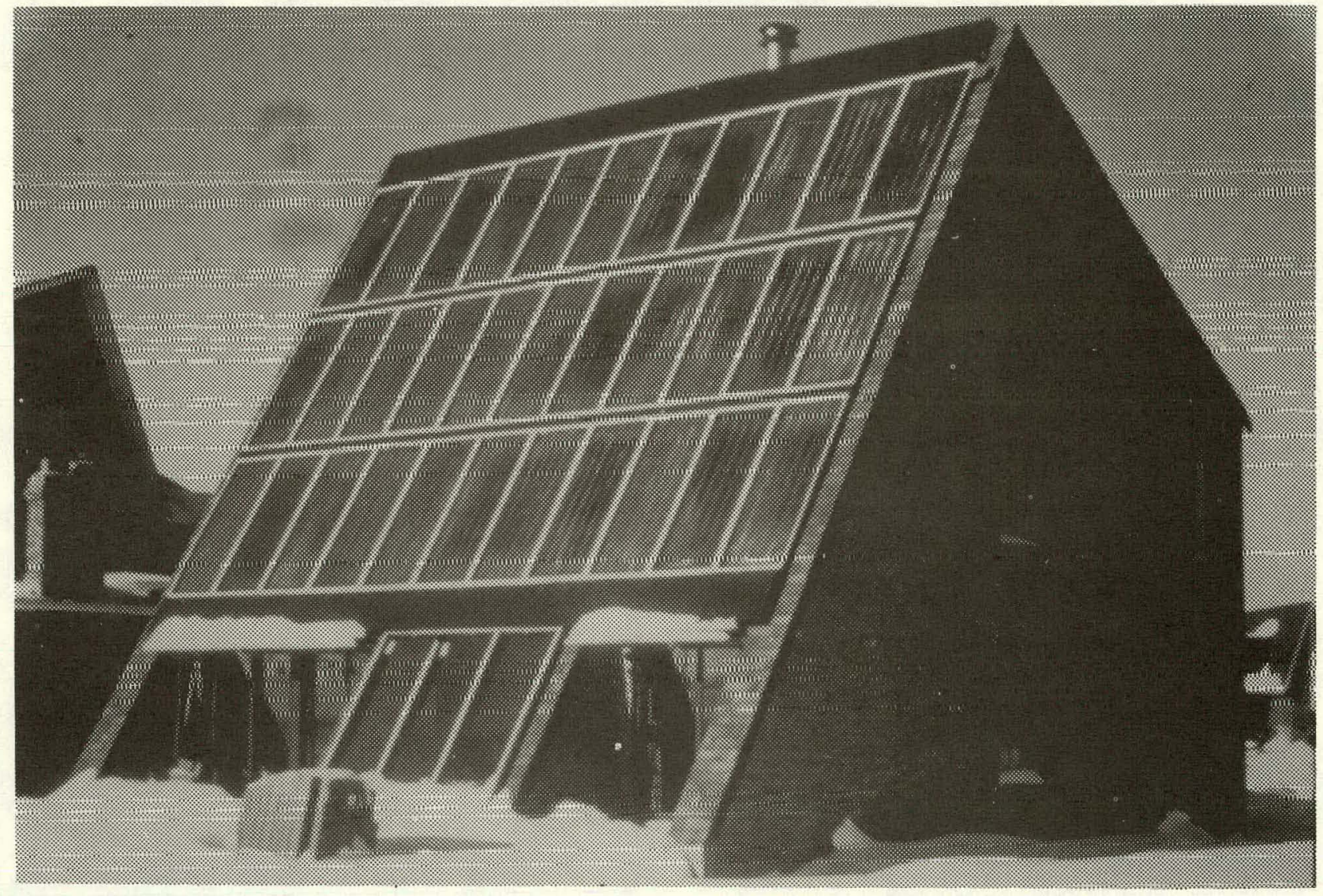

Figure 46

-94- 


\section{MISSISSAUGA SOLAR HOUSE at ONTARIO CANADA}

\section{A. DESCRIPTION}

INTRODUCTION

The Mississauga Solar House in Ontario, Canada, does not approach the energy conservation characteristics of a minimum energy diwelling, although the house is more energy-efficient than conventional houses in Canada.

The objective of the project is to demonstrate the technical feasibility of using a solar heating system with a water/air heat pump to provide heat for domestic water and a part of the space for a single family house under Canadian climatic conditions.

The solar system began operation in November, 1975, and the house has been occupied since that t1me. Monitoring began in October 1976.

\section{CLIMATIC CONDITIONS}

The house is located at a latitude of $43^{\circ} \mathrm{N}$.

The mean annual ambient temperature is $8.9^{\circ} \mathrm{C}$, and the number of heating degree days with the base of $18.3^{\circ} \mathrm{C}$.is 3800 .

\section{DESIGN OF THE BUILDING}

The building is a single-family detached house with $135 \mathrm{~m}^{2}$ of living space on two floors, excluding a heated basement.

The house is designed to utilize the solar heat gain through the south-facing window areas on the first flour.

The walls are insulated with $75 \mathrm{~mm}$ of mineral wool, and the attic is insulated with $200 \mathrm{~mm}$ of mineral wool.

The design space heating load is calculated to 361 $\mathrm{W} /{ }^{\circ} \mathrm{C}$.

\section{SOLAR HEATING SYSTEM}

The energy system consisting of solar collectors, storage tanks and a water/air heat pump provides heat for both space heating and domestic hot water in spring and fall and for only space heating in winter. 
The solar heating system gives priority to space heating over domestic water heating.

If the storage temperature is higher than $50^{\circ} \mathrm{C}$, the warm-air space heating system receives heat from the solar storage tanks directly.

If the storage temperature is between $15^{\circ} \mathrm{C}$ and $50^{\circ} \mathrm{C}$, the space heating system receives heat from the storage tanks through the heat pump.

If the storage temperature is below $15^{\circ} \mathrm{C}$. the space heating system receives heat from the auxiliary electric heater or from a wood-burning fireplace.

In summer, solar energy from storage is pumped to the domestic water preheat tank.

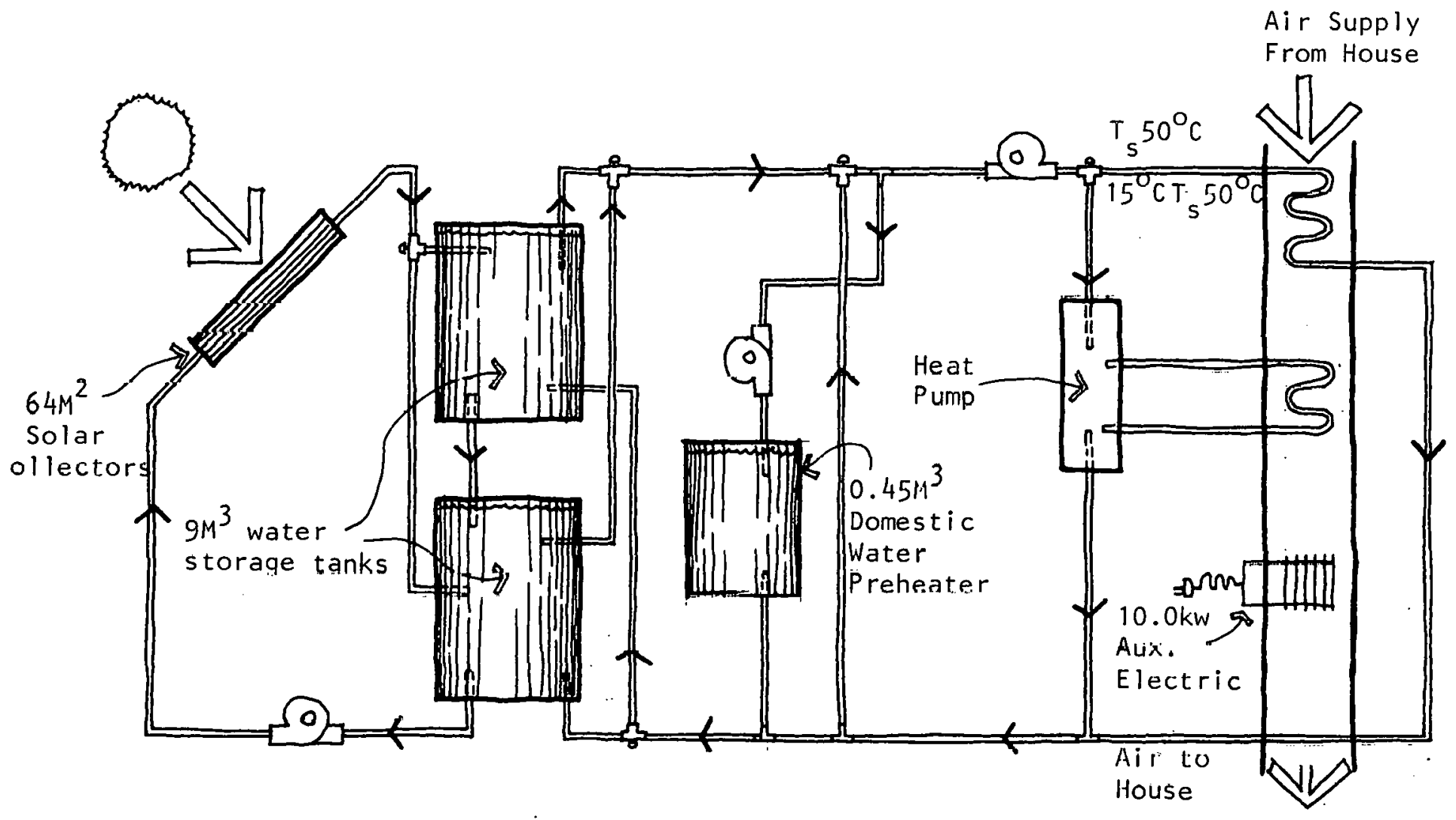


The south-facing solar collectors of $64 \mathrm{~m}^{2}$ with a tilt of $60^{\circ}$ have copper tubes, a copper absorber with selective coating and a single glass cover.

Water is used as the heat transfer medium, and is drained to avoid freezing.

The storage unit consists of two insulated concrete tanks containing $9 \mathrm{~m}^{3}$ of water each, located in the basement. The bottoms of the tanks are not insulated.

The water/air electric heat pump has a heat output of $10 \mathrm{~kW}$ with $15^{\circ} \mathrm{C}$ water entering the evaporator.

OPERATIONAL \& PERFORMANCE RESULTS

B.

MEASURED ENERGY BALANCE

The system thermal performance in the period October 1976 - September 1977 was :

\begin{tabular}{|l|l|l|}
\hline $\begin{array}{l}\text { Space heating requirements } \\
\text { Domestic hot water } \\
\text { requirements }\end{array}$ & $13,000 \mathrm{kWh}$ \\
\hline \multicolumn{2}{|c|}{$\mid$\begin{tabular}{l}
$|c|$ \\
\hline \hline $\begin{array}{l}\text { Solar heat supply for } \\
\text { space heat }\end{array}$
\end{tabular}} & $6,600 \mathrm{kWh}-50 \%$ of load \\
$\begin{array}{l}\text { Solar heat supply for } \\
\text { domestic hot water }\end{array}$ & $1,200 \mathrm{kWh}-21 \%$ of load \\
\hline $\begin{array}{l}\text { Solar used } \\
\text { Solar collected } \\
13,000 \mathrm{kWh} \text { or } 62 \% \text { heat } \\
\text { loss from storage }\end{array}$ & $20,800 \mathrm{kWh}$ \\
\hline $\begin{array}{l}\text { Aux. Energy Used } \\
\text { Space Heat } \\
\text { Hot Water }\end{array}$ & $6,500 \mathrm{kWh}-50 \%$ of load \\
\hline Total Auxiliary Energy & $4,400 \mathrm{kWh}-79 \%$ of load \\
\hline
\end{tabular}


The total cost of solar design, components and installation was $\$ 52,400$ US.

Design, supervision and administration was $\$ 21,800$ US.

Components and installation was $\$ 30,600$ US.

The collector purchase price was $\$ 8,000$ US ( $\$ 125 / \mathrm{m}^{2}$ of collector)

CONCLUSIONS

The solar system fulfills $42 \%$ of the annual space and domestic water heating requirements (mostly through the heat pump).

The solar contribution to the domestic hot water could have been greater, if the solar energy collected in the summer had been used to chlage the domestic water preheat tank before the main storage tanks.

The annual heat loss from storage was $62 \%$ of the total collected energy primarily due to the uninsulated bottoms of the tanks. 


\section{ACKNOWLEDGEMENT}

Information for this section was extracted from a paper by J. R. Sasaki, National Research Council of Canada entitled "Mississauga Solar House", which appeared in the proceedings from the CCMS International Solar Energy Conference in Dusseldorf, FRG on April 19-20, 1979. 


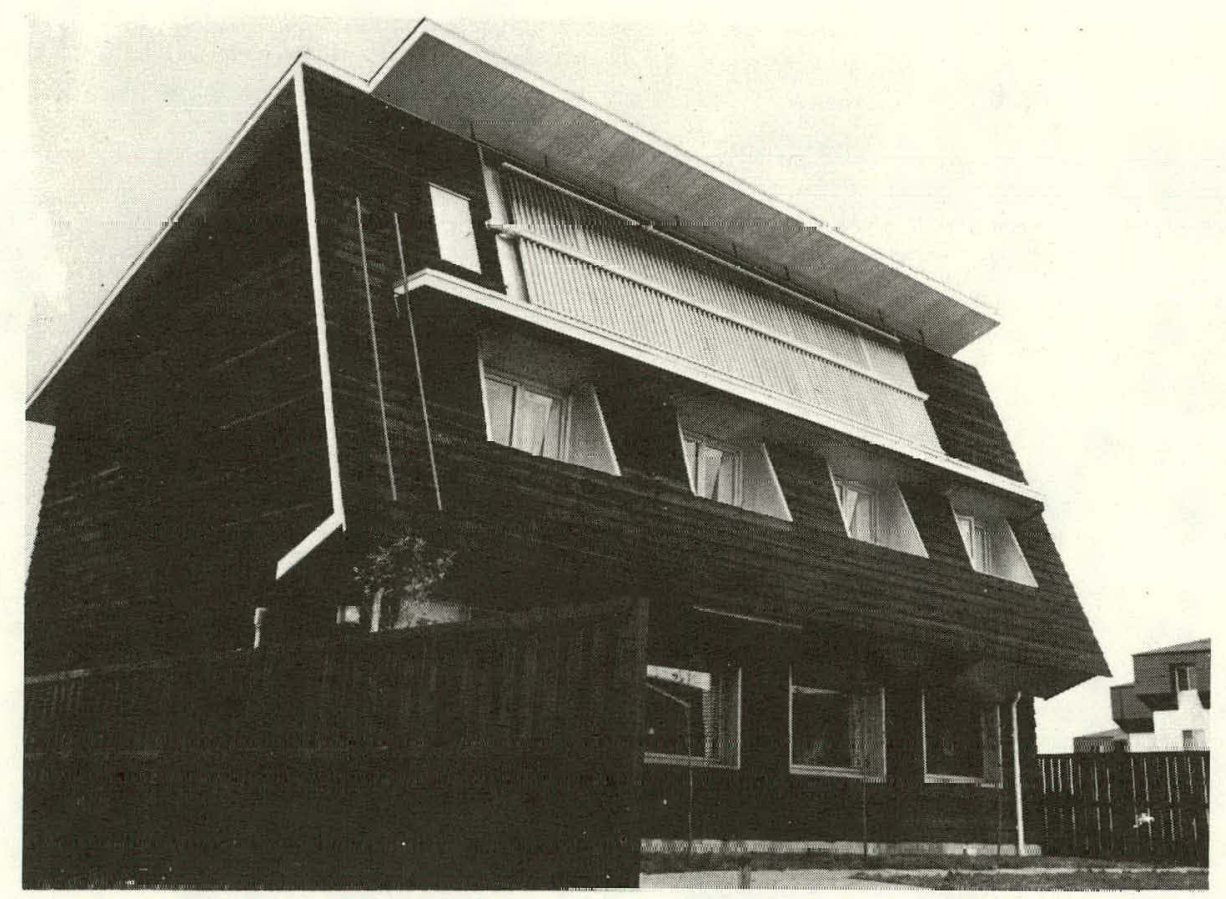

Figure 48

$-100-$ 


\section{SASKATCHEWAN CONSERVATION HOUSE at REGINA, CANADA}

\section{A. DESCRIPTION}

The Saskatchewan Conservation House was completed in December, 1977 in Regina, Canada. The project was an effort by, the Saskatchewan Department of Mineral Resources assisted by the Canadian Research Council, the Universities of Saskatchewan and Regina Development Association of Canada. The house has been operated as a demonstration dwelling open daily to the public. The performance has been monitored, but because of visitors and tours, actual living conditions have not been achieved. During the winter 79-80, monitoring will be ongoing while the house is occupied by a family.

The intention of the construction of the house was to serve as a prototype of the kind of energy conserving design features that the home builders can use to build energy efficient homes.

CLIMATIC CONDIIIONS

Location: Regina, Canada, latitude $50^{\circ} 30^{\prime}$

Mean Value of average ambient January

Temperature $-20^{\circ} \mathrm{C}$

Annual centigrade degree days - 6003

DESIGN OF THE BUILDING

The house is a $186 \mathrm{~m}^{2}$ (93 $\mathrm{m}^{2}$ each): two story design with no basement. The walls are wood frame construction, the first floor is wood framing over a crawl space. The roof is light wood trusses. The south face of the roof has the solar collectors mounted on it.

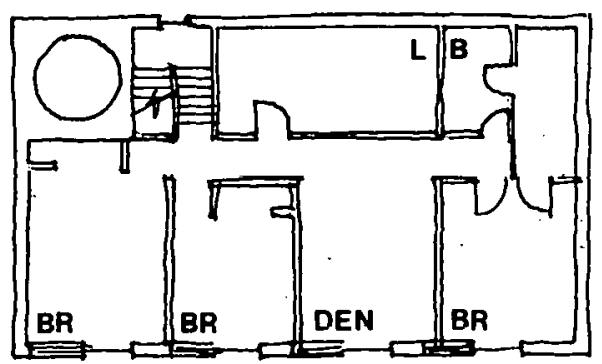

2ND FLOOR

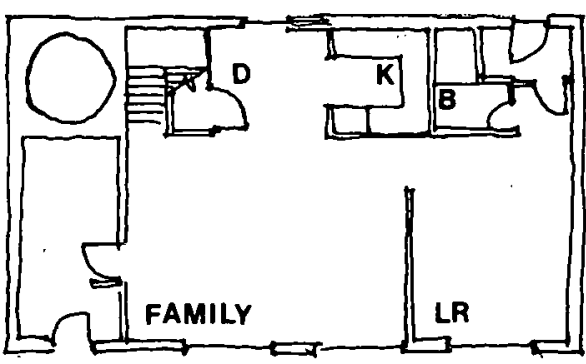

1ST FLOOR 
Fach of the principal rooms of the house is oriented to the south and has windows that function as direct gain passive solar collectors. An overhang over the south windows shades them during the summer to prevent overheating. Auxillary rooms (bath, kitchen) are on the north to reduce the window exposure on the north elevation.

The entries to the house are through air lock spaces to reduce air infiltration in the structure.

\section{ENERGY CONSERVATION MEASURES}

The walls of the house are constructed nf two wood frame walls a total of $305 \mathrm{~mm}$ thick. The lower wall framing is $38 \mathrm{~mm} \times 89 \mathrm{~mm}$ stud frame and $38 \mathrm{~mm}$ $\mathbf{x} 140 \mathrm{~mm}$ etud inncr framc, the seciond level wall is $38 \mathrm{~mm} \times 89 \mathrm{~mm}$ stud outer and inner frame.

The envelope components are insulated to the following $k$-values:

Ceiling

$$
\begin{aligned}
& 419 \mathrm{~mm} \text { cellulose fiber } \mathrm{k}=.09 \mathrm{w} / \mathrm{m}^{2} \mathrm{x}{ }^{\circ} \mathrm{C} \\
& \text { Exterfor Walls } \\
& 304 \mathrm{~mm} \text { fiberglass } \mathrm{k}=.13 \mathrm{w} / \mathrm{m}^{2} \mathrm{x}{ }^{\circ} \mathrm{C} \\
& \mathrm{k}=.38 \mathrm{w} / \mathrm{m}^{2} \times{ }^{\circ} \mathrm{C} \\
& \mathrm{k}=.55 \mathrm{w} / \mathrm{m}^{2} \times{ }^{\circ} \mathrm{C}
\end{aligned}
$$

The house was constructed carefully with attention paid to the integrity of the $150 \mathrm{micron}$ polyethylene vapor barrier. Constructing the house very tightly with an infiltration rate of .05 air changes per hour required a dehumidification and heat exchange mechanical ventilation system be installed to provide for the proper air quality. There is a heat exchanger as part of the ventilation systeiu. Il cuntilete of a plyiwood box with interlocking air channels made of polyethylene. The efficiency of the heat exchanger is about $70 \%$. 
There is also a waste water heat exchanger that captures $20 \%-40 \%$ of the heat from laundry and wash water. The unit consists of a holding tank for the waste water which preheats the water supply to the hot water tank.

\section{SOLAR ENERGY SYSTEM}

The active solar system is a vacuum tube liquid system using $1 / 3$ ethylene glycol and $2 / 3$ water by volume. The array consists of $17.9 \mathrm{~m}^{2}$ of area with a $70^{\circ}$ tilt and they are oriented $21^{\circ}$ west of south. The heat transfer fluid flows from the collector to a heat exchanger. From the heat exchanger, the heat is transferred to a 12,700 liter water storage tank.

The storage tank is used as the heat source for the domestic hot water and the space heat through a $f$ in heat exchanger in the forced air stream.

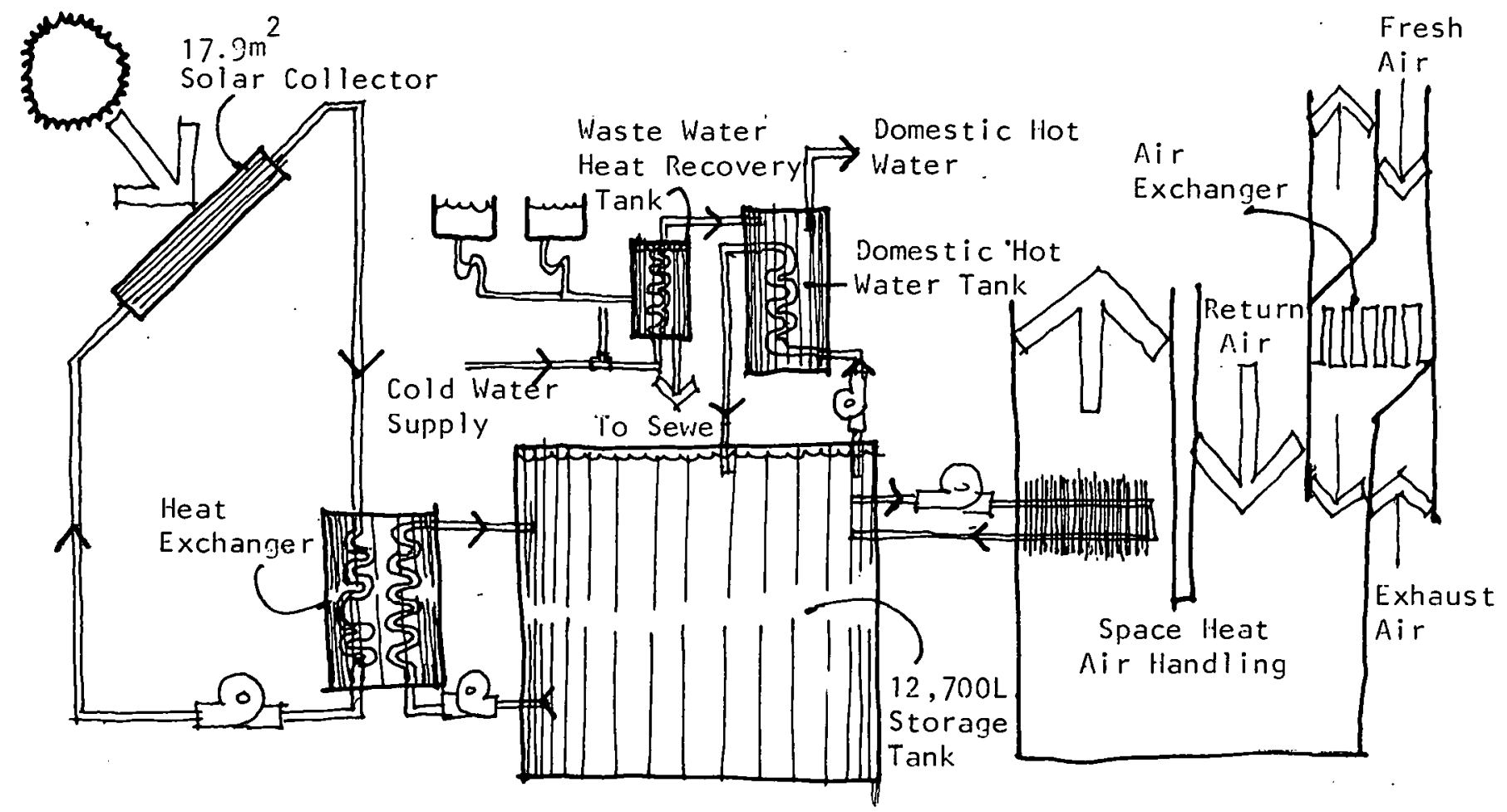

Figure 50 
The house is designed so that a majority of the window area is facing $21^{\circ}$ west of south. The total area of the windows on the south face are $11.9 \mathrm{~m}^{2}$. Each window has its own moveable insulation that has $\mathrm{a} k$ of .38 on the upper floor and .55 on the lower floor.

\section{B. OPERATIONAL AND PERFORMANCE RESULTS}

HEAT LOSS ANALYSIS

The theoretical heat loss of the house based upon the American Society of Heating, Refrigerating and Air Conditioning Engineers (ASHRAE) was $99.1 \mathrm{~W} /{ }^{\circ} \mathrm{C}$ with open shutters and $67.9 \mathrm{~W} /{ }^{\circ} \mathrm{C}$ with insulated shutters closed as at night. The actual heat loss rate 28 moaourcd was. $69.5 \mathrm{~W} /{ }^{\circ} \mathrm{C}$ ds a uverall válue. If the shutters are assumed open 8 hours a day, an average value should be $78.3 \mathrm{~W} /{ }^{\circ} \mathrm{C}$ thus the heat loss value is about $11 \%$ lower than estimated. Some of that value is likely to be due to the sun heating the sutside of the building (sol-air temperature effect).

These heat loss rates compare to a typical house in the area of ahout $250 \mathrm{w} /{ }^{\circ} \mathrm{C}$.

The heat to offset the heat loss on an annual basis has been estimated as follows.

Passive Solar Gain Used $32.6 \%$

People Gain + Elec. Gain $55.6 \%$

Aux. Heat from Solar Collectur

ECONOMIC DATA

The energy rnnservation moasurco incorporatel in the house were estlinilud to cost between $\$ 3,000.00$ - $\$ 5,000.00$ over the cost of a typical house in this area. The active solar system costs $\$ 15,000$. The economic payback for the system is not as atidallve as the economics for energy conservation and passive sular encrgy measures. The energy needed for hot water heating by itself may justify the active collector system costs but not the extensive system that provides space heat as we11 as the hot water. 